Historic, Archive Document

Do not assume content reflects current scientific knowledge, policies, or practices. 

62,23

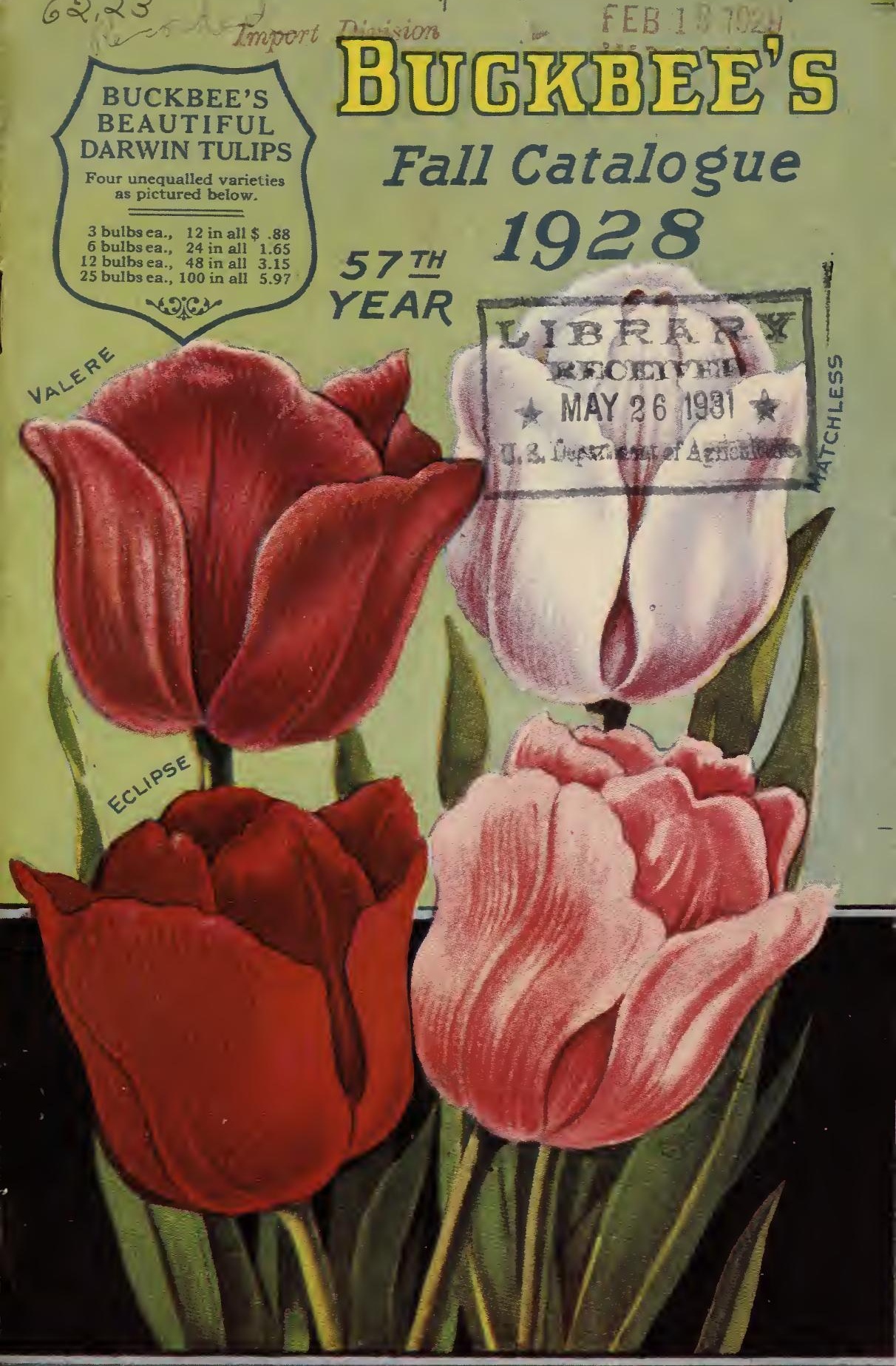

H. W. BUCKBEE, Rockford, Illinois Established 1871 


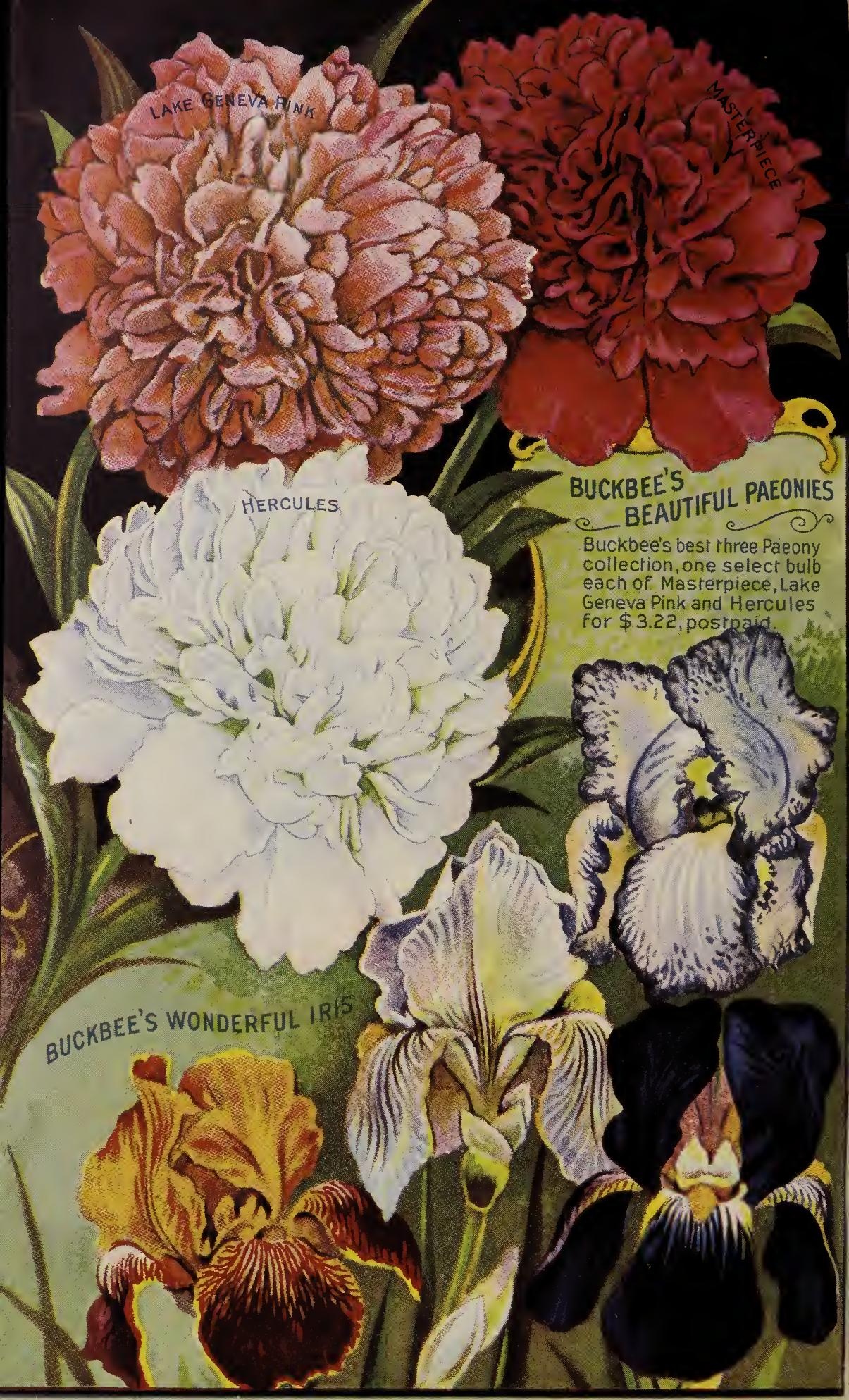

BUCKBEE'S EVER READY QUARTET OF IRIS.

The Four Most Popular Varieties Ever Grown

The Above Complete Set of Four Wonderful Iris for only 75c Postpaid

See Page 5 for Further Varieties of IRIS. Over 26 Varieties to Choose From 


\section{ORDER SHEET FOR}

\section{Buckbee's "Full of Life" Bulbs, Plants and Seeds}

Rockford Seed Farms H.W. BUCKBEE

Rockford, Illinols

Zone.

Name.

(Very Plain)

Please do not write here.

Post Office.

State

R. F. D. No.

Box No.

Street and No.

AMOUNT ENCLOSED

Cash, $\$$

State how much money

Postage Stamps, $\$$ you enclose.

Extra Order Sheets and Envelopes Sent Upon Application.

Be Sure to Read Ordering Instructions, Catalogue Page 40.

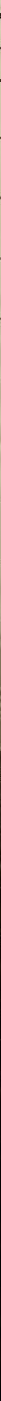




\section{Order Sheet for Bulbs, Plants and Seeds-Continued}

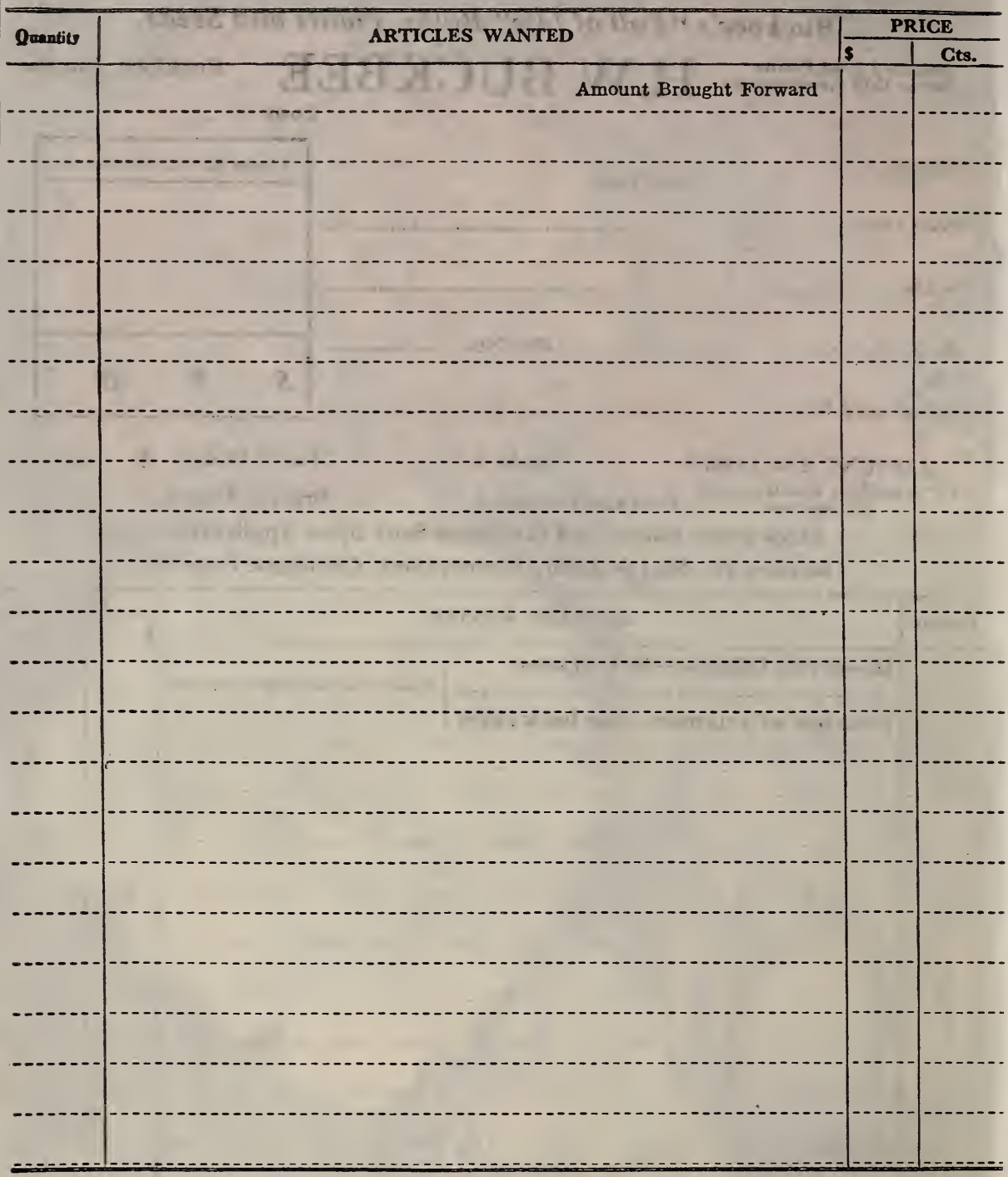

We will be glad to send our Catalogue to your friends if you will write their names and addresses below.

\begin{tabular}{c|c|c}
\hline Names & Post Office & State \\
\hline & & \\
& & \\
& & \\
& & \\
\hdashline & & \\
\hdashline
\end{tabular}


BUCKBEE'S BEAUTIFUL PAEONIES

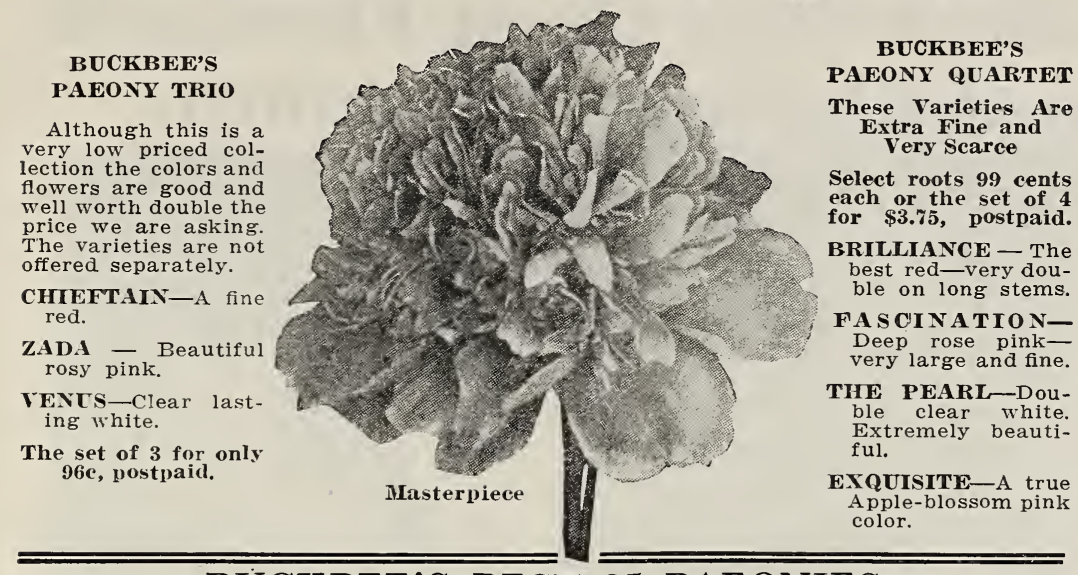

\section{BUGKBEE'S BEST 25 PAEONIES}

If There Are Better Paeonies Than These, We Have Never Seen Them THE BEST 25 PAEONIES IN THE COUNTRY

AMBASSADOR-Handsome buds and flowers. Deep pink outside, lighter inside. 77c each. ARISTOCRAT-Large double flowers-flat type-medium pink of apricot shade. \$1.02 each.

BLUSHING BEAUTY-Blush white turning to pink. Center almost white. Red stamens. 87e each.

DISTINCTION-Cherry red or very dark rose. Large flowers on long stems. \$1.27 each. EXCELSIOR-Large buds. Guard petals are white with a center of cream. 83e each. GIGANTEA-Very large, dahlia flowered pink. High double crown, self color. 78c each. HERCULES - This is a double pure white and the largest flower we have. \$1.23 each. IDEAY Medium double, rather dwarf and late. Dark pink shaded lighter. 64c each. LA FRANCE-Flat type, very double. Pinkish salmon and white blended. \$1.03 each. LAIKE GENEVA PINK-Wonderful clear pink buds and flowers of large size. \$1.16 each. LOVELINESS-Early, medium tall. Outer petals white; crown cream, touched with red. 76c each.

MAIDEN'S BLUSH-Apple blossom pink. Buds pink. High crown lemon and white. $66 \mathrm{e}$ each.

MASTERPIECE-Dwarf double, medium size. Solid rose color with a few yellow stamens. $\$ 1.34$ each.

MONARCH-Medium size, deep rich red. z2c each.

ORIENT-The rose flowered Paeony. Tall and double. Guards dark rose, center lighter

color. 81c each.
PERFETION-Early light pink. Guards rose-crown sulphur. Center tuft edged red. $93 \mathrm{c}$ each.

PROGRESSION-Guards shell pink. Crowns double row of yellow, balance pink edged rose. \$1.04 each.

PCRITY - Pure white collar with a sulphur white crown. 73c each.

ROSY GEM-Dwarf double. Very high crown. Self color, rose turning to apricot. $82 \mathrm{c}$ each. SENSATION-Beautiful large deep red, but only semi-double. A real sensation.
91c each.

SNOWDRIFT-Deliate clear white with a fleck of crimson in center of crown. 84c each. TRIUMPH-Medium early red. Strong vigorous grower, good color. 9\%c each.

UNIQUE-Deep rose pink, tipped with silver pink. Large and double. 94c each.

VESUIIS-Dark carmine rose or medium red. Fairly double and type good. 68c each. WHITE HAWK-Semi-double-tall-long buds. Guards dark pink, center sulphur pink. 6ric each.

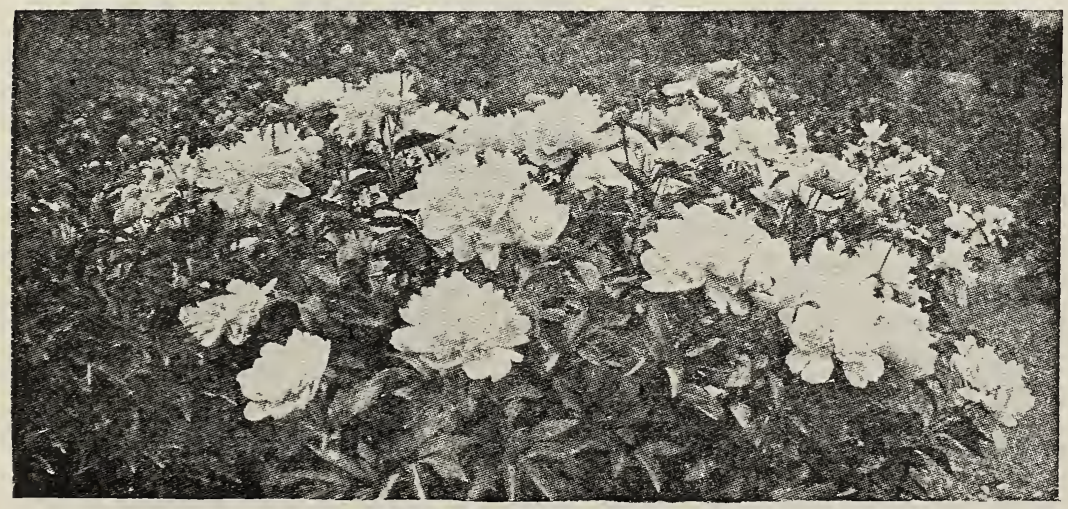

Buckbee's New Paeony-La France 


\section{Buckbee's Giant Flowered Exhibition Hyacinths}

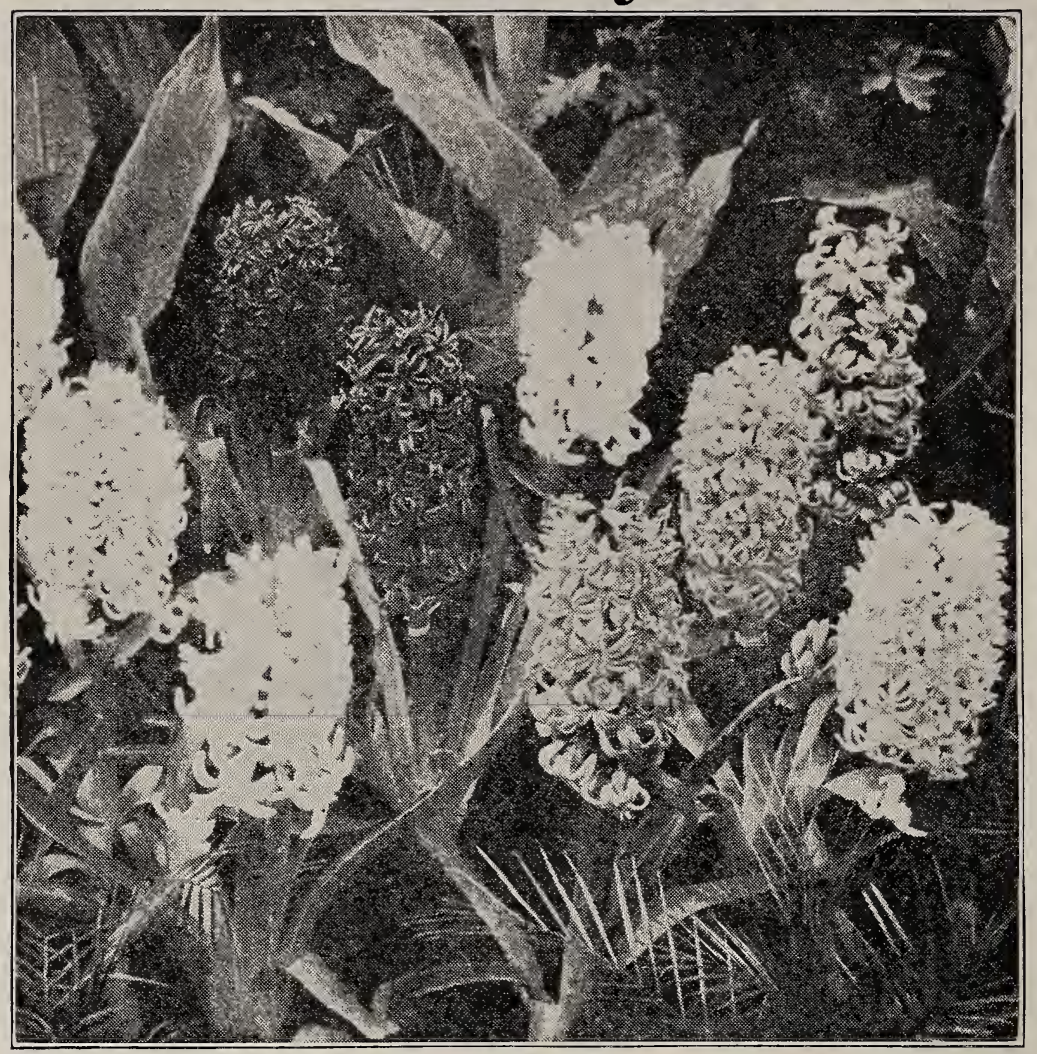

These Are the Best That Can Be Secured

We import these extra select Bulbs especially for those of our customers who wish to grow Extra Fancy Giant Flowers. They will do equally well in pots or glasses in the house, or out of doors.

Price of any of the Giant Flowered Exhibition Hyacinths on this page: 25c each; 3 for 69c; doz. $\$ 2.07$, postpaid.

ADMIRATION-Always pleases as it is an unusual shade of Porcelain Blue. Unusually large spikes of flowers with bells of perfect shape.

DIANA-Light blue color and a very pleasing pot plant. The bells are large and closely arranged on a well shaped spike.

ELEGANCE-Fine deep crimson-this is a color that always pleases. There are few red flowers in the early spring, and this one should please you.

GOLD FINCH-The finest of the yellows. The flowers are large and last well. This is an unusual color in Hyacinths and generally comes true.

GRANDEUR--Delicate rosy-pink-a shade of color you seldom see. Whether grown in the house or out of doors, you will find this a very acceptable variety.

IDEAL-Always comes pure white. Long spikes with large snowy-white bells. Early-fine for forcing and for bedding.

JUBILEE-Delicate rosy pink. Extra large-early and easily grown. Very compact spikes on long stems.

MIMMI-Blush white-we consider this one of the very best. Bears splendid large trusses which are always in fine shape and form.

MONARCH-Deep, indigo blue. Acknowledged the best of the blues and purples. A strong growing variety and exceptionally desirable. 


\section{Buckbee's "Full of Life" Hyacinths}

Unequalled to Grow in Pots in the House

\section{HY A C IN T HS}

For Winter and early Spring flowering, nothing surpasses the Hyacinth. Sure to bloom and give satisfaction in the house during Winter, or in the garden in early Spring. TVe consider the Single Hyacinths more useful and valuable than the double varieties. They are better for forcing, more vigorous in growth, and produce stronger spikes of bloom, which are at least as beautiful as those of the double sorts.

Our stock of Hyacinths consists of the finest bulbs, sure to bloom, and were grown by the most reliable growers in Holland, and have been selected with the utmost care as regards varieties that in our judgment will give the verv best results for outdoor or house culture. Our assortment contains the cream of all the more lesirable sorts, and we take this opportunity to assure intending purchasers that these bulbs cannot be obtained to better advantage elsewhere.

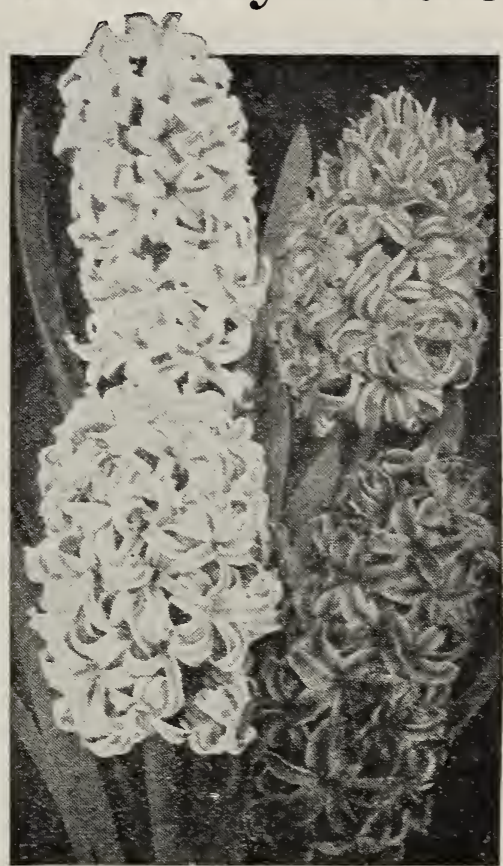

Buckbee's "Full of Life" Hracinthe

\section{BUCKBEE'S "FULL OF LIFE" \\ BEST NAMED HYACINTHS NEWEST VARIETIES}

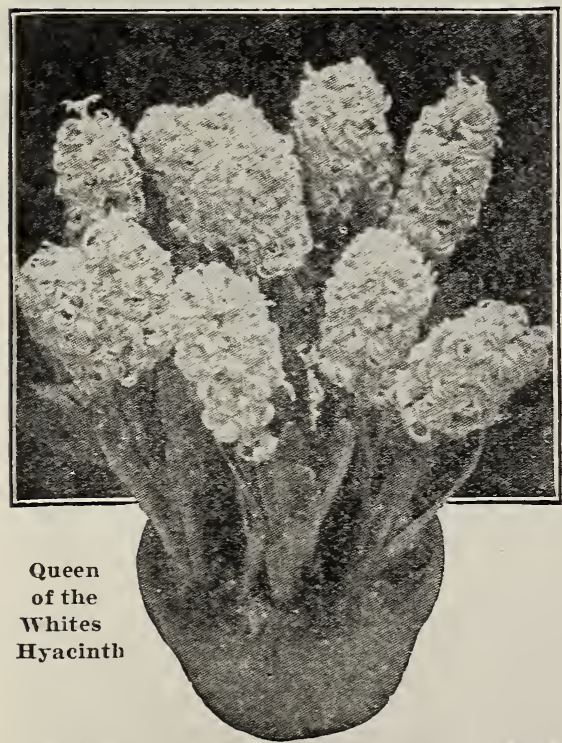

Prices on 12 bulbs or less, postpaid; larger quantities by express collect.

While these Bulbs do nicely inside. they are laryely used for Bedding out of doors, as the price is low enough to permit liberal plantings.

Beauty-Lorely shade of light pink or rosy white. Good size.

Electra-Light porcelain blue. Large spike.

Excelsior-Rost pink; compact flower. Fine for pots or out of doors.

Fing of the Scarlets-Dark red, very fine truss and a popular sort.

Marie-Darkest blue. almost black. A new color and rery satisfactory.

Queen of the Whites-Snow white, perfect shape and of large size.

Simplicity-Blush white. A beautiful flower, unsurpassed for bedding.

Yellow Hammer-Golden rellow. The earliest and best 5ellow for forcing.

Price any of the abore, each $19 \mathrm{c} ; 3$ for $55 \mathrm{c} ;$ doz. $\$ 1.71 ; 50$ for $\$ 6.25$.

BCCKBEE'S "FULL OF LIFE" SPECIAL MIXTCRE SINGLE HYACINTHS

The rers best colors and shades in special mixture. Price, 3 for 52c; doz. \$1.57; 50 for $\$ 5.75$.

FINE MIXED

Fine Mulbs, 6 for $70 \mathrm{c}$; doz. $\$ 1.39 ; 50$ for $\$ 5.13$ 


\section{"Full of Life" ROMAN HYA GINTHS}

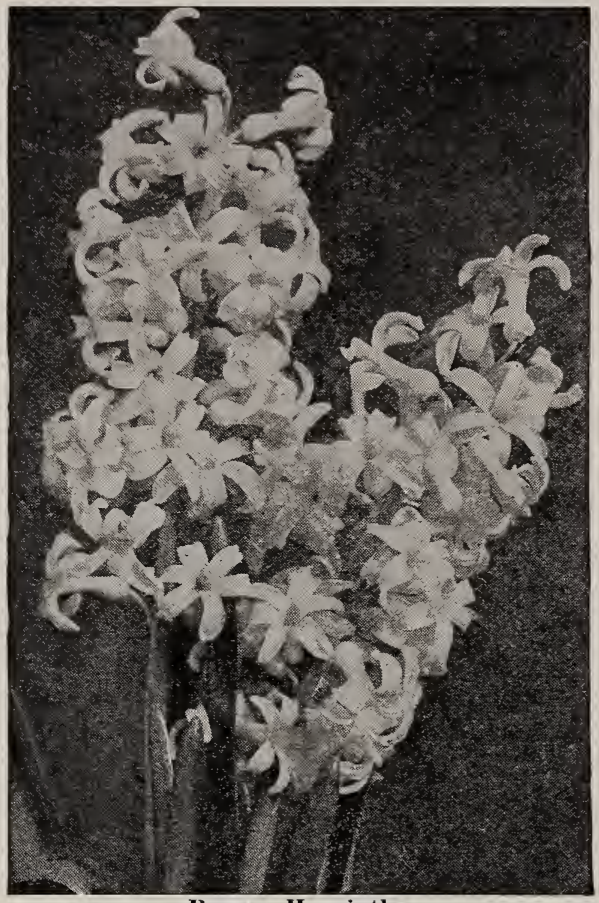

Beautiful, small size Hyacinths, similar to but smaller than the regular Hyacinths shown on the preceding page. All are especially desirable for pots, pans and boxes.

The following are the best of the Romans :

Albertine-Pure clear white.

Amy-Rich bright carmine.

Brutus-Nankeen yellow, one of the best.

Grand Blanche-Delicate blush white.

Jacques-Rose pink. Very early.

Johan-Beautiful light blue.

Nador-Deep blue. Very desirable.

Price any of the above Roman Iryacinths 2 for $29 \mathrm{c}$; doz. $\$ 1.32 ; 50$ for $\$ 4.88$.

I like your Seeds, Bulbs and Plants better than any $I$ have ever grown. The Bulbs I ordered from you in the fall are all doing nicely. Ethel S. Fall, Canton, No. Car.

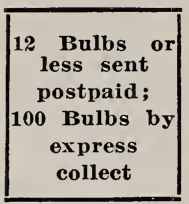

BUCKBEE'S HEAVENLY BLUE GRAPE HYACINTHS

These very curious and pretty little Hyacinths are perfectly hardy, and of the easiest culture, they thrive and increase in either sunny or partially shaded positions in the garden. All are also adapted for winter flowering in the house. Price 6 for $26 \mathrm{c}$; doz. $51 \mathrm{c}$; 100 for $\$ 3.48$.

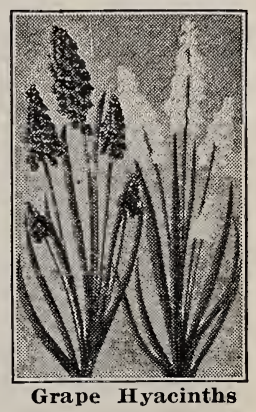

\section{Buckbee's "Full of Life" MINIATURE OR PAN HYACINTHS}

\section{A Rare Novelty from Holland}

A class of Hyacinths with comparatively small bulbs, and as they are usually compact growers, can be more cheaply grown than the larger bulbed class. While the spikes scarcely arerage as heary as other Hyacinths, the difference is small, and many specimens are fully equal to the best of the latter.

$\begin{array}{lll}\text { Pure White } & \text { Red } & \text { Light Blue } \\ \text { Blush White } & \text { Dark Blue } & \text { Yellow }\end{array}$

Blush White $\quad$ Yellow

Price of Pan Hyacinths, 2 for $28 \mathrm{c}$; dozen $\$ 1.25 ; 50$ for $\$ 4.63$.

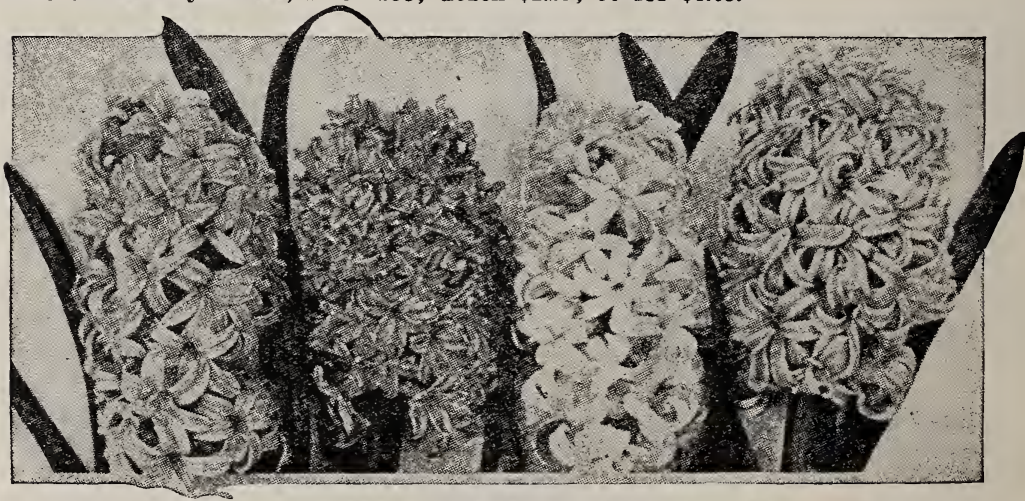




\section{BUCKBEE'S "FULL OF LIFE" IRIS}

The Most Wonderful Colorings of Any Flower Except the Orchid

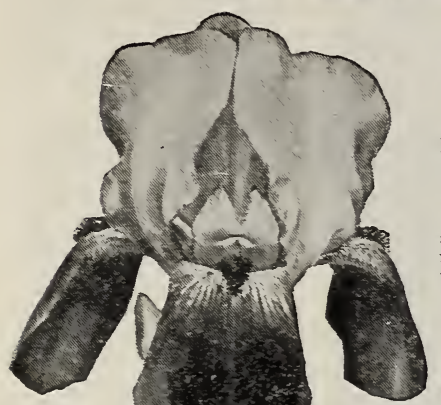

Buckbee's Oriental Iris Marvels

Four Peerless Iris as Pictured on This

We want all to grow the Beautiful Iris and offer one fine Bulb each of:

Bronze Beauty

Hector

Marmora

Queen of the May

Each one labeled separately for only $\$ 2.75$, Postpaid.

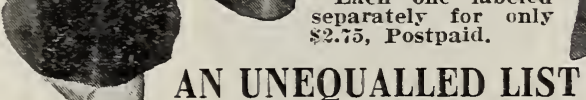

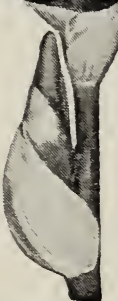

Marmora

\section{AN UNEQUALLED LIST}

Whatever you want-a few com. mon ones for the back yard, or rare and fancy varieties for the fancier, we have them. Our varieties are well worth having.

Four of One Variety at 3 Times Single Plant Price

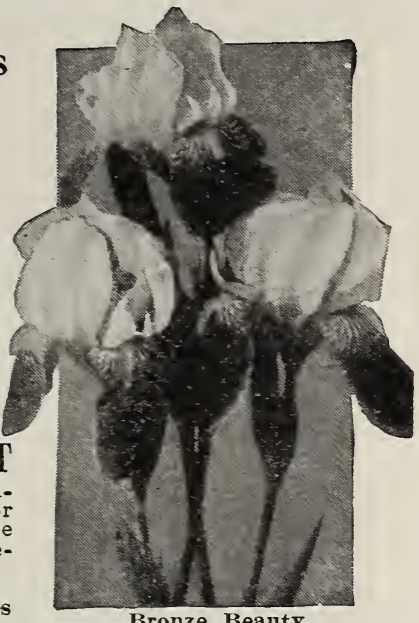

Bronze Beauty AGNES - White and HER MAJESTY-A beautiful pink. $85 \mathrm{c}$.
lilac. ALBERT VICTORRosy lavender, striped

AMAS-Deep violet and bright riolet. 70c. SSUERUS - Carmine violet and yellow. $80 \mathrm{c}$. BALCENZ-Pale blue and striped. 75c. BERCHTA-Straw sellow and carmine riolet. $40 \mathrm{c}$. BRONZE BEAUTY-Amber, heliotrope and bromn.

CANARY BIRD-Clear, pale yellow. 80c. CAPRICE-Dark violet rose. $40 \mathrm{c}$.

CONTE DE ST. CLAIR-Violaceous white, blotched. $35 \mathrm{c}$.

FAIRY - White with green mid-rib. 45c. FAUSTINE-Light blue-edged purple. $50 \mathrm{c}$. GYSELS SLATY — Blue spotted white. 50c. JEANNE D'ARC-SLT blue with edging. LORELEY-Yellow and purple. 25c. MARMORA-Sulphur, famn and crimson. 90c. MONSIGNEUR-Larender shaded rellow. 50c. NIBLEGEN-Rosy lavender-striped. $40 \mathrm{c}$ NULL O'ORANGE-Smoky lilac. 80c.

PACQUITTE-Rosy claret. 50c.

PALLIDA MADALACEA-Creamy slate and lapender. $35 \mathrm{c}$.

PSEUDO ACONIS-Tellow Siberian, 45c. QUEEN OF THE GYPSIES-Dusty sellow and QUEEN OF THE MAY-Clear bright rose. $85 \mathrm{c}$. RETICULATA PURPUREA-Lilac and purplemottled. 85c.

SAMBUCINO-Coppery rose and purple: 60c. TERESSA-Slate blue mottled purple. $25 \mathrm{c}$. VENUS-Sage and white reined brown. 750 HECTOR-Mother of Pearl and brown. 70c.

We will send 4 of any one rariety for 3 times the single price postpaid

\section{FANCY IRIS IN MIXTURE}

This assortment is made up from over 20 varieties, many of which are too scarce to list separately.

3 for $70 c ; 6$ for $\$ 1.30 ; 12$ for $\$ 2.50$, postpaid

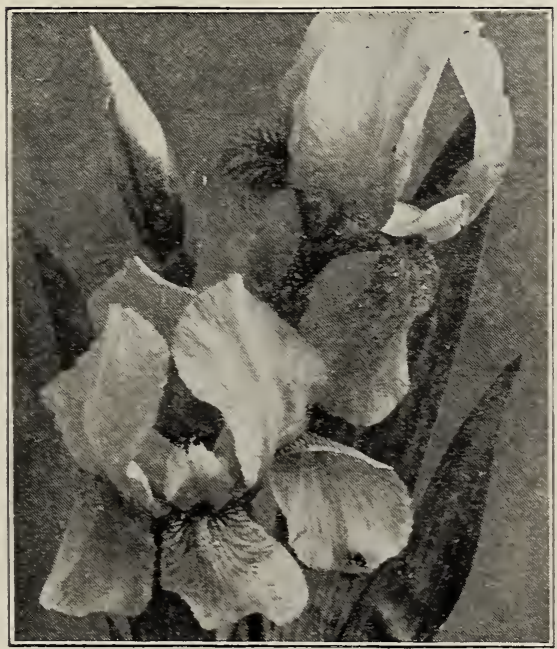

Queen of the May

\section{Special Offer Extraor- dinary}

The Most Popular Varieties of Iris Known

DARICS-Fellow and violet.

MAD. CHEREAC -White edged blue.

PERPLE PRINCE-Rich dark blue.

WAXY WHITE-Cream striped lilac.

1 Root each of the 4 for $\% 5$, Postpaid.

3 Roots each of the 4 for \$2.10, Postpaid.

6 Roots each of the 4 for $\$ 3.90$, Postpaid.

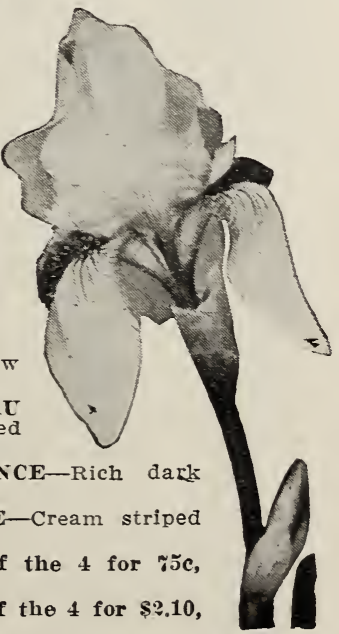




\section{Buckbee's "Full of Life" DARWIN TULIPS}

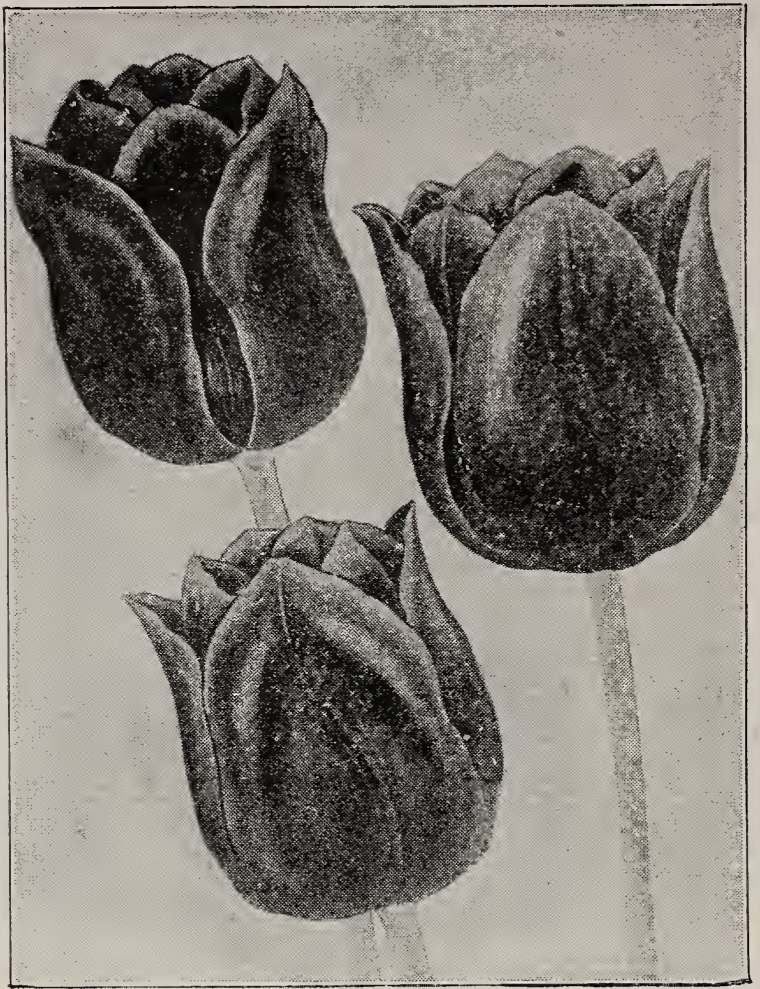

Darwin Tulips are more largely grown every year and considering the splendid form and exquisite coloring, the immense size of the numerous varieties, it is not surprising that these flowers have obtained great popularity.

They are late Mayflowering tulips but are quite distinct in style of growth from others of this class; they are very stately in appearance, attain a height of 2 to 3 feet and bear on long stems beautiful. globular flowers of lasting wax-like substance in a great variety of brilliant colors.

They are exceedingly effective when grown in groups of a dozen or more in the garden; as cut flowers they are unsurpassed and in pots these tulips are also lovely and can be successfuliy flowered in the house if grown in a cool room and not forced into bloom before March.

\section{Darwin Tulips}

These wonderful flowers are so effective, when grown in separate colors, that we rate colors, that we varieties as well as the mixtures.

Afterglow - A very pretty color, being bright rose with a distinct margin of a

Darwin Tulip-Giant

lighter color 2 for $24 c ; d 0 z \$ 1.08,50$ for $\$ 4.00 ; 100$ for $\$ 7.48$.

Eclipse-Glowing crimson violet with a blue base, long strong stem and a sure bloomer. 3 for $20 \mathrm{c} ;$ doz. 60c; 50 for $\$ 2.25 ; 100$ for $\$ 3.99$.

Flava - A rich clear vellow, almost golden yellow, Makes a wonderful contrast when grown with other colors 3 for $22 \mathrm{c} ; \mathrm{doz} 65 \mathrm{c} ; 50$ for $\$ 2.50 ; 100$ for $\$ 4.47$

Giant-A very large flower. Quite fragrant. The rosy carmine color is relieved by a steel blue base, very effective. 2 for $22 \mathrm{c}$; doz. $98 \mathrm{c} ; 50$ for $\$ 3.63 ; 100$ for $\$ 6.74$.

Livingstone-A delightful shade of lilac rose, the entire shading down to almost blush white 4 for $20 c ;$ doz $90 c ; 50$ for $\$ 3.38 ; 100$ for $\$ 6.23$

Longfellow-Almost pure white when fully open. Buds slightly tinted rose. 2 for 18c: doz. $80 \mathrm{c} ; 50$ for $\$ 3.00 ; 100$ for $\$ 5.46$.

Mad. Barrios-Silky purplish rose-center; dark violet shaded bronze. A wonderfully effective coloring. 3 for $25 \mathrm{c}$; doz $75 \mathrm{c} ; 50$ for $\$ 2.88 ; 100$ for $\$ 5.25$

eftect on our list it is very beautiful,

Paul Eudel-Although this is one of the lowest priced on our

Pink Perfection-Silvery pale rose flushed white. Inside soft pink with white center marked

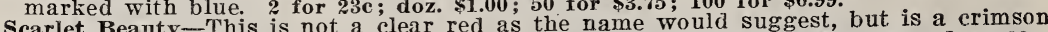
violet. One of the most satisfactory Darwins we have. 2 for 19c: doz. 88c 50 for $\$ 3.25 ; 100$ for $\$ 5.9 \%$.

\section{Darwin Tulips in Assorted Colors}

Thousands of our customers prefer a mixture rather than a solid color in their bulb beds, so we hare prepared these special mixtures to meet this demand.

Buckbee's "FCLL OF LIFE" Mixture contains a rery select assortment of Darwins. Many varieties which are too scarce to offer separately are included in this mixture, as well as dozens of different colors and shadings. We believe that this is the best assortment that can be obtained anywhere. 6 for $35 \mathrm{c}$ : doz. 68c; 50 for $\$ 2.63 ; 100$ for $\$ 4.72$.

Elite Mixture-Not quite equal to the "FULL OF LIFE" assortment but contains a rery fine collection of colors and varieties. Doz. 45e; 50 for $\$ 1.85 ; 100$ for $\$ 3.15$.

12 bulbs and less sent postpaid. Larger quantities by express collect.

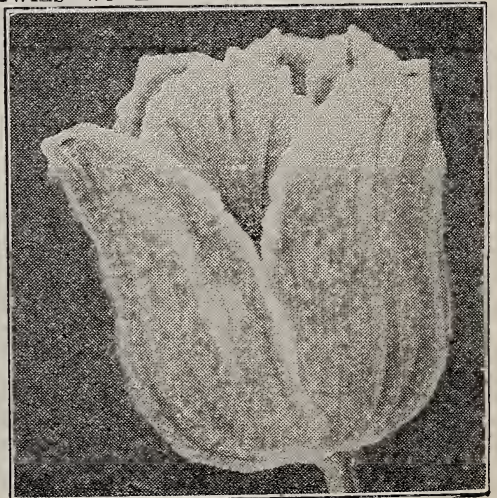

Darwin Tulip-Afterglow 


\section{Buckbee's "Full of Life" Darwin Tulips}

\section{AMAZEMENT}

\section{The Most Wonderful} Tulip Ever Grown

Darwin Tulips are without question the finest flower that can be had in bloom out of doors in the early Spring. Our collection has always been very complete, but our new Amazement is so far ahead of anything else that it is really in a class by itself.

Our Holland grower calls it a lilac color but that name fails to describe the beautiful coloring of this flower. The color seems to be a combination of rose, lilac, lavender and purple, all blended together, making a color never seen before.

Flower stems are 18 to 24 inches long, and blossoms are very large. 2 for $25 \mathrm{c}$; doz. $\$ 1.10 ; 50$ for $\$ 4.13 ; 100$ for $\$ 7.76$.

The Tulips that I got of you last Fall are the talk of the town. The most beautiful I ever saw.

Mrs. Geo. H. Arend, irattoon, Ill.

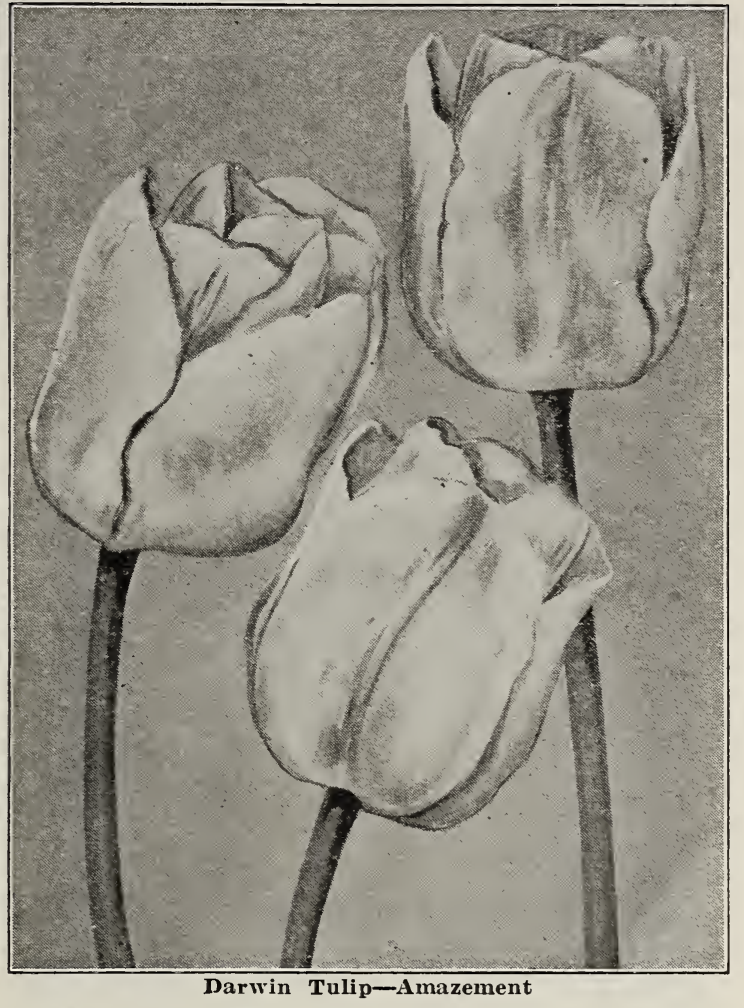

DARWIN TULIPS

The varieties on this page and those on page 6 are all of the best colors of the Darwins. Our bulbs are carefully grown and are sure to please.

Aphrodite-A new variety and a fine flower. Clean pink shaded or flushed to a rosy salmon. 2 for $23 \mathrm{c}$; doz. $\$ 1.00 ; 50$ for $\$ 3.75 ; 100$ for $\$ 6.98$.

Carmen-Carmine rose shaded lighter. Extra fine. Medium large flower. 3 for 24 ; doz. $70 \mathrm{c} ; 50$ for $\$ 2.75 ; 100$ for $\$ 4.99$.

Coquette-Bright rose margined blush rose. Long stemmed large flowers. Good keeper. 3 for 21c; doz. 62c; 50 for $\$ 2.38$; 100 for $\$ 4.24$.

Gold Medal-One of the best yellows, stems are long and flowers of good size. Lasts well when cut. 3 for $19 \mathrm{c}$; doz. $55 \mathrm{c} ; 50$ for $\$ 2.13 ; 100$ for $\$ 3.75$.

Lafayette-A very pretty color of soft rosy lilac flushed white with white base. 2 for $19 \mathrm{c} ;$ doz. 85c; 50 for $\$ 3.13 ; 100$ for $\$ 5.74$.

Matchless-A very dark colored flower, being purplish rose shaded bronze. It has been well named as it is a wonderful flower. 2 for $20 \mathrm{c} ; \mathbf{d o z} .90 \mathrm{90} ; 50$ for $\$ 3.38 ; 100$ for \$6.23.

Queen Marie-One of the lightest colored Darwins ever grown. Color is silvery rosy white or almost a peach blossom pink. 2 for $24 \mathrm{c}$; doz. $\$ 1.08 ; 50$ for $\$ 4.00 ; 100$ for $\$ 7.46$.

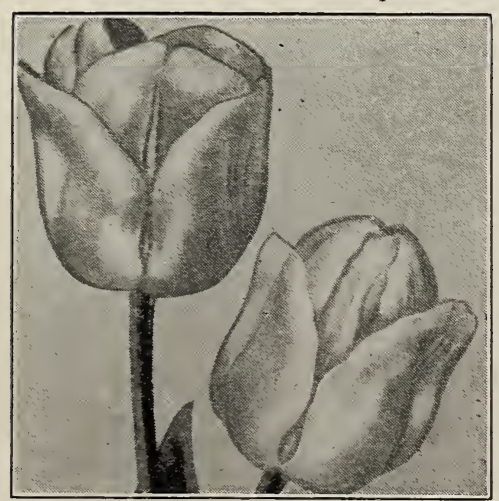

Valere and Aphrodite

The Dove-As near a pure white as you can get in the late Darwins. Flowers are large and well shaped and show only a tint of pink, being mostly creamy white. 3 for $2 \%$; doz. $80 \mathrm{c}$; 50 for $\$ 3.00 ; 100$ for $\$ 5.47$.

Valere-Brilliant rosy carmine with blue base. Quite sweet scented; a ver attractive and showy flower in the garden. 2 for 22c; doz. 98c; 50 for $\$ 3.63$; 100 for \$6.71.

Village Maid-Soft carmine rose, edged lighter shade. Verv large flowers carried on long, strong stems well above the foliage. 2 for $21 \mathrm{c}$; doz. $95 \mathrm{c}$; 50 for $\$ 3.50$; 100 for $\$ 6.48$.

SPECIAL OFFER 26E-One bulb of each of the 11 Darwin Tulips on this page (each one labeled separately) for only $96 \mathrm{c}$ postpaid.

SPECIAL OFFER $26 \mathrm{~F}$ - One bulb each of the 21 Darwin Tulips on this page and page 6 (each one labeled separately) for only $\$ 1.81$, postpaid.

12 bulbs and less sent postpaid. Larger quantities by express collect. 


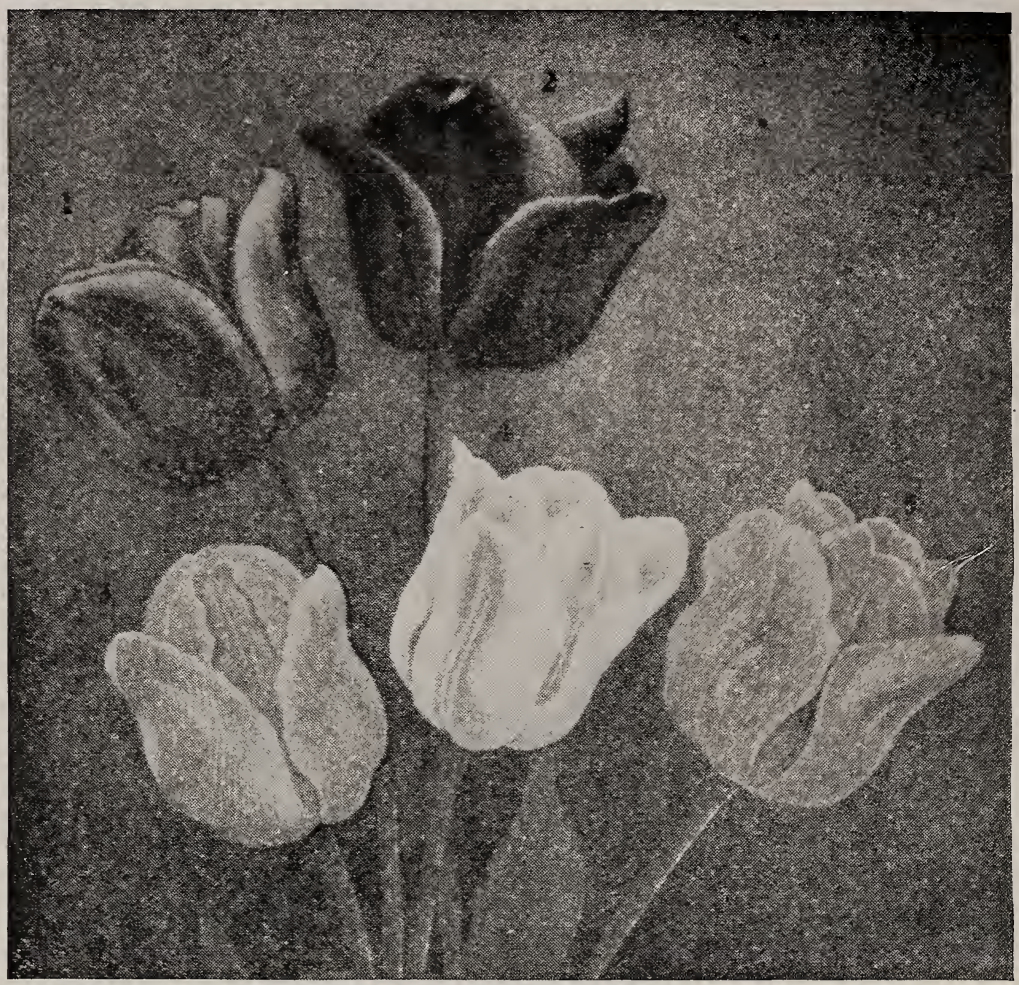

\section{Buckbee's "Full-of-Life" Breeder Tulips}

\section{The Most Desirable Class of Tulips Ever Grown}

A picture can only give a faint idea of the beauty of these flowers and, although pictured from life, do not begin to show the wonderful grace and beauty of these beautiful flowers.

On this page are pictured and described the five varieties which we can recommend as being absolutely the best you can secure and are well worth the small difference in cost over the varieties shown on the next page.

The figure after the variety name corresponds with the figure in the picture above.

BROWN THRUSH-1-Dark brownish red. It is unusual to see a flower like this, and we believe it is the finest Breeder erer grown. When full grown it is of immense size, held upright on long strong stems. 2 for $25 \mathrm{c}$; 6 for $59 \mathrm{c}$; dozen $\$ 1.14$; 50 for $\$ 4.25 ; 100$ for $\$ 7.99$.

VELVET KING-2-This is a velv ty black with brown shading and very beautiful. Stems are long and strong and the blossoms large and true cup shaped. This is one that will show up well in any location. 2 for $25 \mathrm{c} ; 6$ for $57 \mathrm{c}$; dozen $\$ 1.10$; 50 for $\$ 4.13 ; 100$ for $\$ 7.73$.

WATER LILY-1-Creamy white softly tinted with heliotrope when first opening. Good sized flowers on dark stems; flower somewhat resembling a water lily. 2 for $26 \mathrm{c} ; 6$ for $61 \mathrm{c}$; dozen $\$ 1.18 ; 50$ for $\$ 4.38 ; 100$ for $\$ 8.26$.

ROSE QUEEN-5-A delightful shade of color, being an old rose, flushed orange salmon. This is the color so much in demand for cut flowers. Our stock grows long, strong stems which hold the large flowers to a good height. 2 for 24c; 6 for 55e; dozen $\$ 1.05 ; 50$ for $\$ 3.88 ; 100$ for $\$ 7.22$.

ORCHID-3-A beautiful two-toned flower, of clear pink and salmon rose. Flowers are good and square, cup shaped and of large size. Long stems raise the flowers well above the foliage. 2 for $24 \mathrm{c} ; 6$ for $56 \mathrm{c}$; dozen $\$ 1.08 ; 50$ for $\$ 4.00 ; 100$ for $\$ 7.47$.

\section{BUCKBEE'S BREEDER TULIPS IN ASSORTMENTS}

Where one has only a limited amount of space in which to plant Tulips, a mixture is desirable, as it will give an assortment of colors at a rery reasonable price.

BUCKBEE'S “FULL OF LIFE” MIXTCRE--This mixture cannot be excelled no matter what price you pay nor how many you get. We have made this mixture ourselves from the best assortments our growers could supply, and added some of every variety listed on this page and page nine. 6 for $51 \mathrm{c}$; dozen $98 \mathrm{c}$; 50 for $\$ 3.63 ; 100$ for $\$ 6.74$.

SELECT MIXED-A fine mixture of many colors and shades and well worth more than the low price we ask. Dozen for $60 \mathrm{c} ; 50$ tor $\$ 2.25 ; 100$ for $\$ 3.95$.

12 bulbs or less sent postpaid; larger lots by express collect. 


\section{Buckbee's "Full of Life" Breeder Tulips}

The Most Beautifully Colored of Any Tulip

Breeder Tulips are very similar in habit to the Darwins and flower at the same time. Their chief characteristic is their immense blooms, borne on strong, stiff stems, many of them longer than the most gigantic Darwins.

The reriral of the taste for art colors has made these Tulips, at one time rers popular in England, strong farorites with American enthusiasts, who find in their bronze, buff and brown shades excellent material for contrasting with the light and bright colors of the Darwins.

No home is complete without its perennial border or garden, and no perennial bed can be complete without its Spring Flowering Bulbs. The Breeder and Darwin Tulips hare an important part in making the garden complete, as their wonderful and unusual colors, coming at a time when nothing else is in bloom, adds a touch of beauty which cannot be replaced by any other flower.

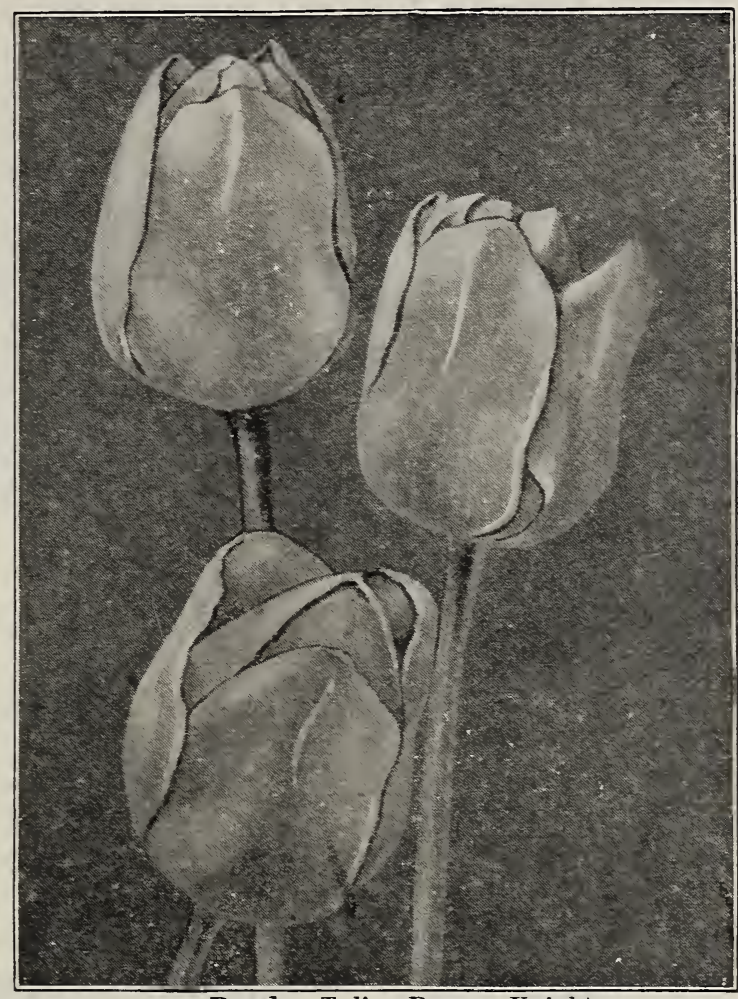

Breeder Tulip-Bronze Knight

\section{BREEDER TULIPS}

There are hundreds of rarieties of this wonderful flower, from which we have selected the following as being the best for the amateur as well as the Tulip specialist. All the best colors are in our list below.

Black Chief-This is a fine flower and heads our list owing to its low price but splendid qualities. Color black and brown. 3 for 20c; doz. 60c; 50 for \$2.25; 100 for \$3.99.

Bachus-One of the darkest of all of the Breeders, being dark purplish Violet; always gives splendid satisfaction. 2 for $19 \mathrm{c}$; doz. $85 \mathrm{c}$; 50 for \$3.13; 100 for $\$ 5.74$. Bronze Knight-There are few if ans that can equal the exceptional colors of this flower. The general effect is brown, being buff inside, tinged golden bronze. 2 for $21 c$; doz. $95 c ; 50$ for $\$ 3.50 ; 100$ for $\$ 6.49$.

Gorgeous-Tery desirable flower with long strong stems. Color bronze shading to olive brown, 3 for 23c; doz. $68 \mathrm{c} ; 50$ for $\$ 2.63 ; 100$ for $\$ 4.73$.

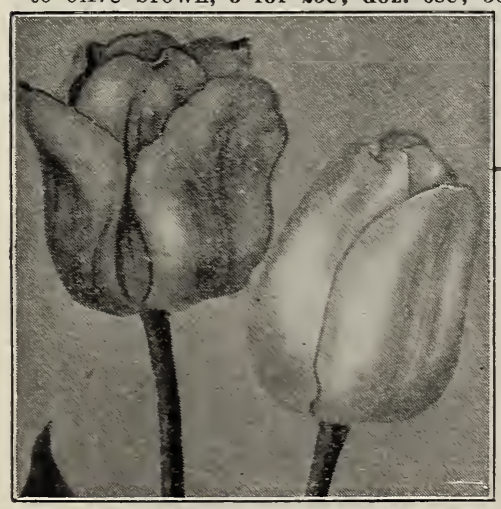

Olive and Turquoise

Le Mogol-Tery delicate color for a late Tulip, being best described as a soft Lilac. 3 for $21 \mathrm{c}$; doz. $62 \mathrm{c}$; 50 for $\$ 2.38$; 100 for $\$ 4: 22$.

olive-Large flowers, long stems, good keeper. Color dark bronze shaded orange and rellow. One of the finest. 2 for 19c; doz. $88 \mathrm{c}$; 50 for $\$ 3.25 ; 160$ for $\$ 5.98$.

Orange Perfection-This is a color that does not fade but lasts well either on the plant or when cut. Brown tinged orange. 3 for $24 \mathrm{c}$; doz. $70 \mathrm{c}$; 50 for $\$ 2.75$ : 100 for $\$ 4.97$.

Turquoise-Beautiful ros 5 riolet with a blue base. Alwars shows up well whererer grown. 2 for $20 \mathrm{c}$; doz. $90 \mathrm{c}$; 50 for $\$ 3.38 ; 100$ for $\$ 6.23$.

vulcain-This is as red as it is possible to get a Breeder, being a rich salmon carmine. Large flowers and long stems. 3 for $22 \mathrm{c}$; doz. $65 \mathrm{c}$; 50 for $\$ 2.50 ; 100$ for $\$ 4.49$.

Dozen bulbs and less are sent postpaid. Larger quantities sent by express collect. 


\section{Buckbee's "Full of Life" DOUBLE EARLY TULIPS}

Double Tulips produce very large double flowers, many of which are as large and showy as a Paeony. The bright colors of the large double blossoms contrast splen.

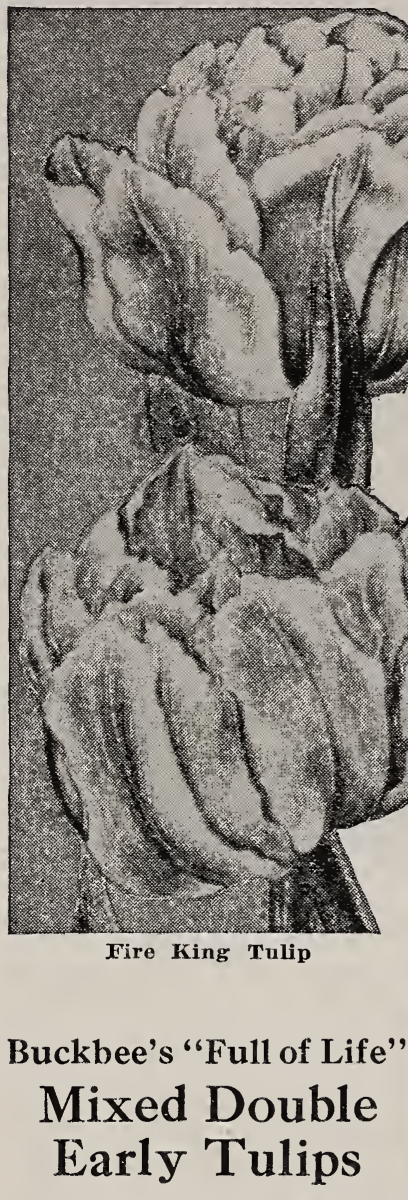

The best varieties of Double Early Tulips are comprised in this finest of all mixtures. You will make no mistake by ordering this assortment. Selected Bulbs, 6 for $34 \mathrm{c}$; doz. 65c; 100 for $\$ 4.45$.

\section{Double Early 'Tulips Mixed}

Selected varieties mixed carefully together in such proportion as will give a beautiful array of colors. All blooming at the same time. Price, doz. 42c; 100 fer $\$ 2.99$.

12 Bulbs or less sent postpaid; 100 Bulbs by express collect. didly and make a charming display. They are beautifully adapted for beds on the lawn, in the garden and for mingling in clumps of half a dozen or more around the edges of shrubbery. Ther are exceedingly effective. The early sorts do splendidly. when grown in pots for winter blooming, but must be forced much slower than single Early Tulips by keeping them cooler. The following varieties are the most highly improved of the Double Tulips. The colors are desirable and flowers beautiful.

Annie--Splendid deep rose pink and very double.

Fire King-Pure deep red color. One of the newest. 3 for $29 \mathrm{c}$; doz. $88 \mathrm{c} ; 50$ for \$3.25.

Gloria Solis--Clear bright red with a distinct border of brightest orange yellow.

Luminosa-Splendid bright scarlet; the finest of all the double scarlets for forcing.

Peach Blossom-Finest light pink or blush white. Full very double flowers. 3 for 29c; doz. 88c; 50 for \$3.25. Snow White-Beautiful pure white. Medium early and a fine flower.

Tournesol-Red bordered yellow. Large flower, easy to grow.

Yellow Perfection-Large double yellow; early and an unusual color.

Price of the above, except where noted, 3 for $22 \mathrm{c}$; doz. $65 \mathrm{c} ; 100$ for $\$ 4.45$.

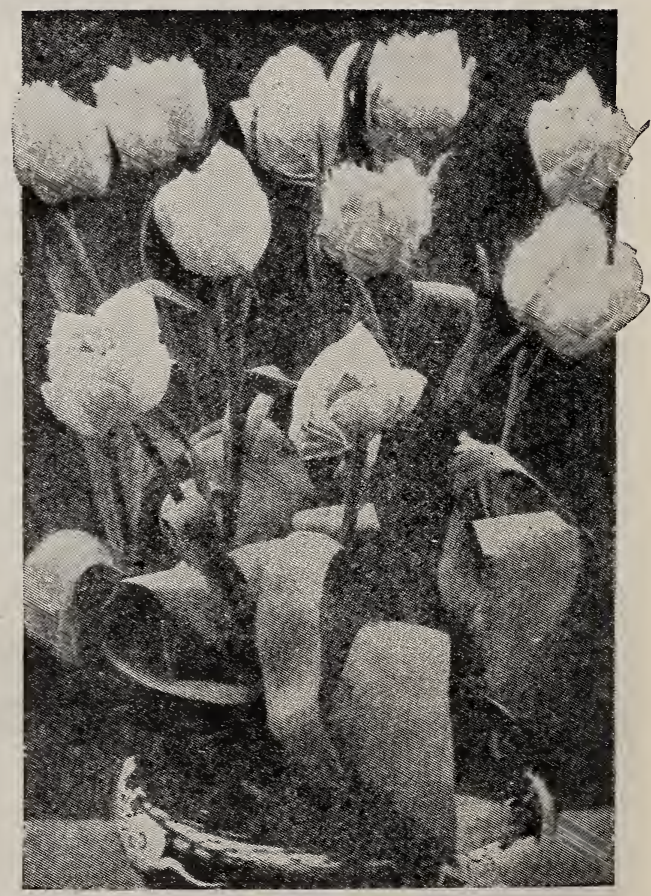

Peach Blossom Tulip 


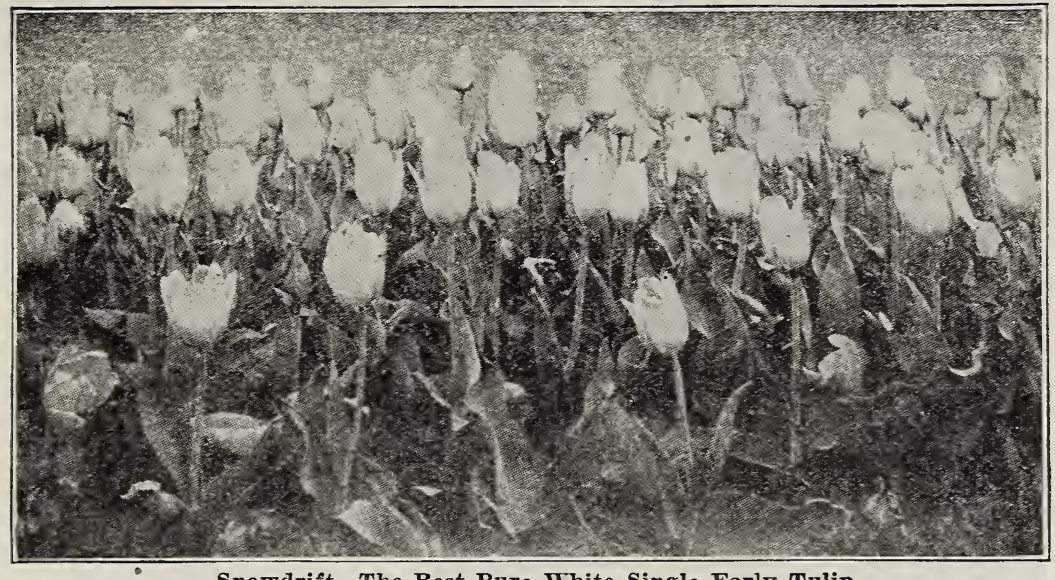

Snowdrift-The Best Pure White Single Early Tulip

\section{BUCKBEE'S “FULL OF LIFE"

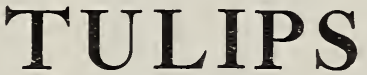

The people are appreciating the beauty of Tulips more and more erery vear. There is so little trouble in bringing them to perfection, whether planted out or in pots, and they are so raluable that no garden or window should be without them. For gorgeous colors and brilliant effects planted in beds and borders the Tulip stands unrivaled. There are no bulbs which make such a rich display of blossoms with so little care and cultivation. As with most flowers, single rarieties succeed better than double when forced. For this purpose ther should be planted as early as possible.

Although there are many hundreds of varieties of single Tulips, we have selected only those which will gire the best results, and which slow the most desirable colors and shades. The following can be depended upon for general satisfaction.

\section{Buckbee's Best Named Single Early Tulips}

The Single Early Tulips are grand for outdoor bedding and for Winter blooming in pots. The following are the very best kinds:

Alice Rooserelt-Large flower of a pleasing shade of rose.

Brilliant Star-Bright scarlet; dwarf, good bedder, 3 for $24 \mathrm{c}$; doz. 70c; per $100, \$ 4.99$.

Buttercup-Pure golden yellow; fine for forcing or beddins.

Cottage Boy-Bright orange scarlet-bordered sellow.

Enchantress-Beautiful rich crimson. Tery select.

Keizerskroon-Crimson scarlet; edged bright yeliow. Large showy flower.

President Taft-Rose and pink, beautifully blended.

Snowdrift-Exquisite elegant flower of large size. Pure white; 3 for $25 \mathrm{c}$; doz.

75c; 100 for $\$ 5.19$

Price any of the above desirable single Early Tulips except where especially marked 3 for $21 \mathrm{c}$; doz. $62 \mathrm{c} ; 100$ for $\$ 4.26$.

\section{Buckbee's "Full of Life"} Mixed Single Early-Flowering Tulips

Selected named varieties carefully mixed together in such proportion as will gire a beautiful arras of colors. All blooming at the same time. Price, 6 for 33c; doz. $62 \mathrm{c} ; 100$ for $\$ 4.26$.

\section{Single Early Tulips-Mixed}

The sorts usually sold by dealers; good value for the money, but not to be compared with our "Full of Life" mixture. Price, doz. $49 \mathrm{c} ; 100$ for $\$ 2.99$.

Prices on 12 bulbs or less include postage. The 100 rates are by express at purchaser's expense.

The Tulip Bulbs rou sent me last rear were beautiful.

Miss Mattie Trump, Paddy, Mo.

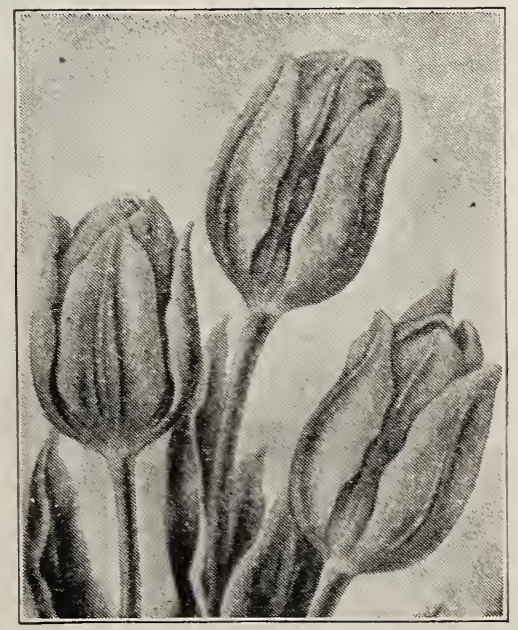

New Tulip-Brilliant Star 


\section{PARROT OR DRAGON TULIPS}

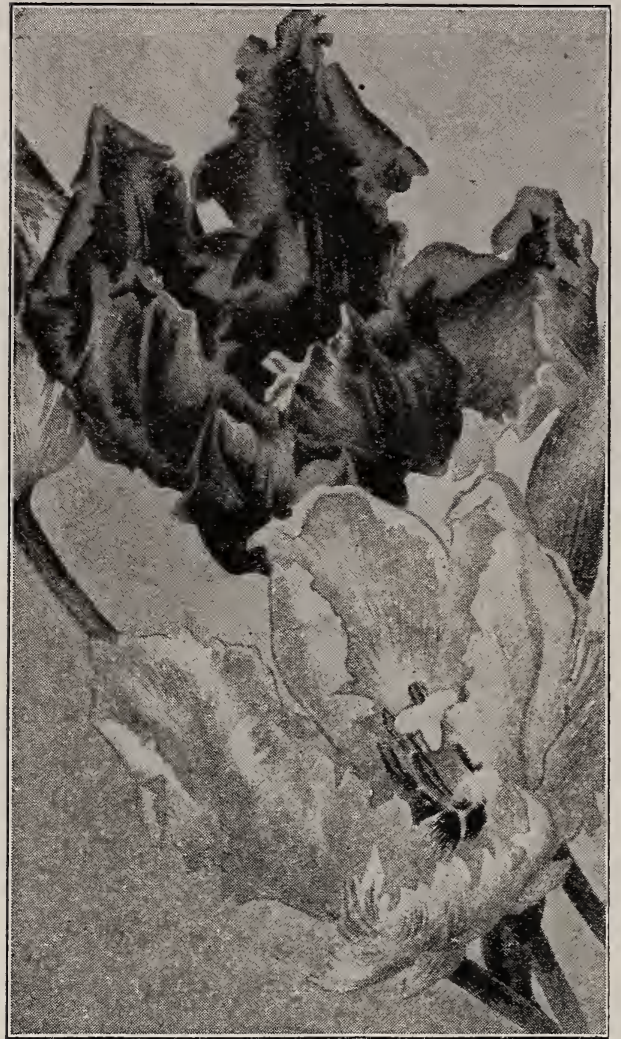

Parrot or Dragon Tulips

\section{FOR THE OPEN GROUND ONLY}

Absolutely Different in Shape and Coloring from Any Other Tulip

The most beautiful and interesting class of Tulips, which should be in every garden, as there is no other family of hardy garden flowers that offers an equal range. The Parrot Tulips make the best color display of the year. Coming in May, following the daffodils and early tulips, and just preceding the iris, they lend an interest to the garden which cannot be equaled. It is advisable to plant these tulips in groups in the border, with background, rather than in open beds. At least twelve should be used to make a group while fifty would be much better, and the rare colorings and shapes are wonderfully decorative. The flowers are very large and perfect in shape, the petals are corrugated and toothed, while color is the most striking combination of crimson and golden yellow, streaked and edged with green, resembling the plumage of a parrot, whence these tulips derive their name. $A$ bed of these makes a gorgeous display, paying hundred-fold for any trouble that may be bestowed upon them.

Price, Select Bulbs, 6 for 24c; doz. $45 \mathrm{c} ; 100$ for $\$ 3.25$.

\section{Buckbee's Beautiful May Flowering Tulips}

One of the Best of the Garden Tulips.

These Tulips are quite distinct from the early flowering kinds-coming later, they extend the blooming season two or three weeks longer, and are usually at their best about Decoration Day. They are exceedingly hardy and therefore excellent for planting in the perennial border or among the shrubbery, where they remain undisturbed for years. The colors and markings of late Tulips are truly magnificent. Buckbee's Superfine MixedEveryone should have at least a dozen of these beauties. All the best colors assorted. Price 6 for 23c; doz. 42c; 100 for $\$ 3.15$.

NOTICE-Send in your order for bulbs at once and we will ship as soon as stock arrives from Holland, usually early in September. 12 Bulbs or less sent postpaid. 100 or more by express collect.

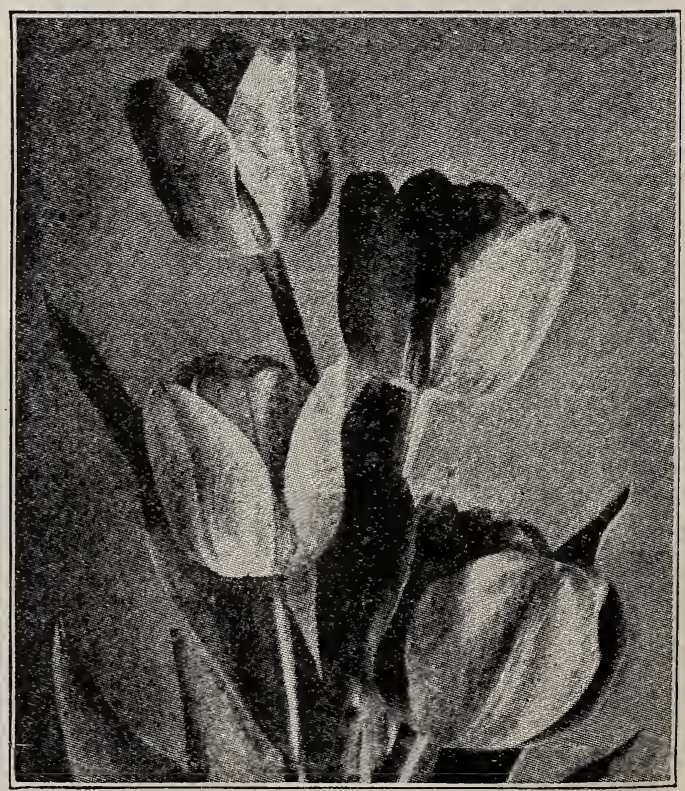

Buckbee's May Flowering Tulips 


\section{BERMUDA EASTER LILY} (Lilium Harrisii)

The Grandest Winter-Flowering Plant in Cultivation

Is of the Easiest Culture, Blooming in Wonderful Abundance.

The flowers are delightfully fragrant, pure waxy white, of great substance, and if cut as soon as they open, or partially open, they can be-kept with stems in water, for two weeks. A succession of bloom can be kept up from Norember to May, by bringing in a few pots of bulbs from cold frames at intervals through out the Winter.

The quantity of bloom produced is marrelous: the arerage production of selected bulbs, erei when forced, is from 4 to 6 flowers, and of mammoth bulbs 8 to 12 flowers.

Extra Selected Bulbs-Each 41c; 3 for \$1.19, postpaid.

Mammoth Bulbs-Each 53c; 3 for \$1.52, postpaid.

\section{JAPANESE EASTER LILIES}

Beautiful Flower. True Type. About two weeks later than the Bermuda

This improred type of the well known Lilium Longiflorum, also called the "Easter or St. Joseph's Lily," comes from the Island of Formosa. The plants are of strong, healthy growth about 3 feet high, and produce bealltiful snow - white trumpet - sh a ped flowers, 6 to 8 inches long. It is perfectly hardy (if given a little protection) and a splendid garden lily blooming in the open in June and July. This Lily is also a rery important winter flowering type, thousands of the bulbs being imported for cut flowers. Fine Select $\mathrm{Bulbs}$, each $39 \mathrm{c}$; 3 for $\$ 1.14$; postpaid.
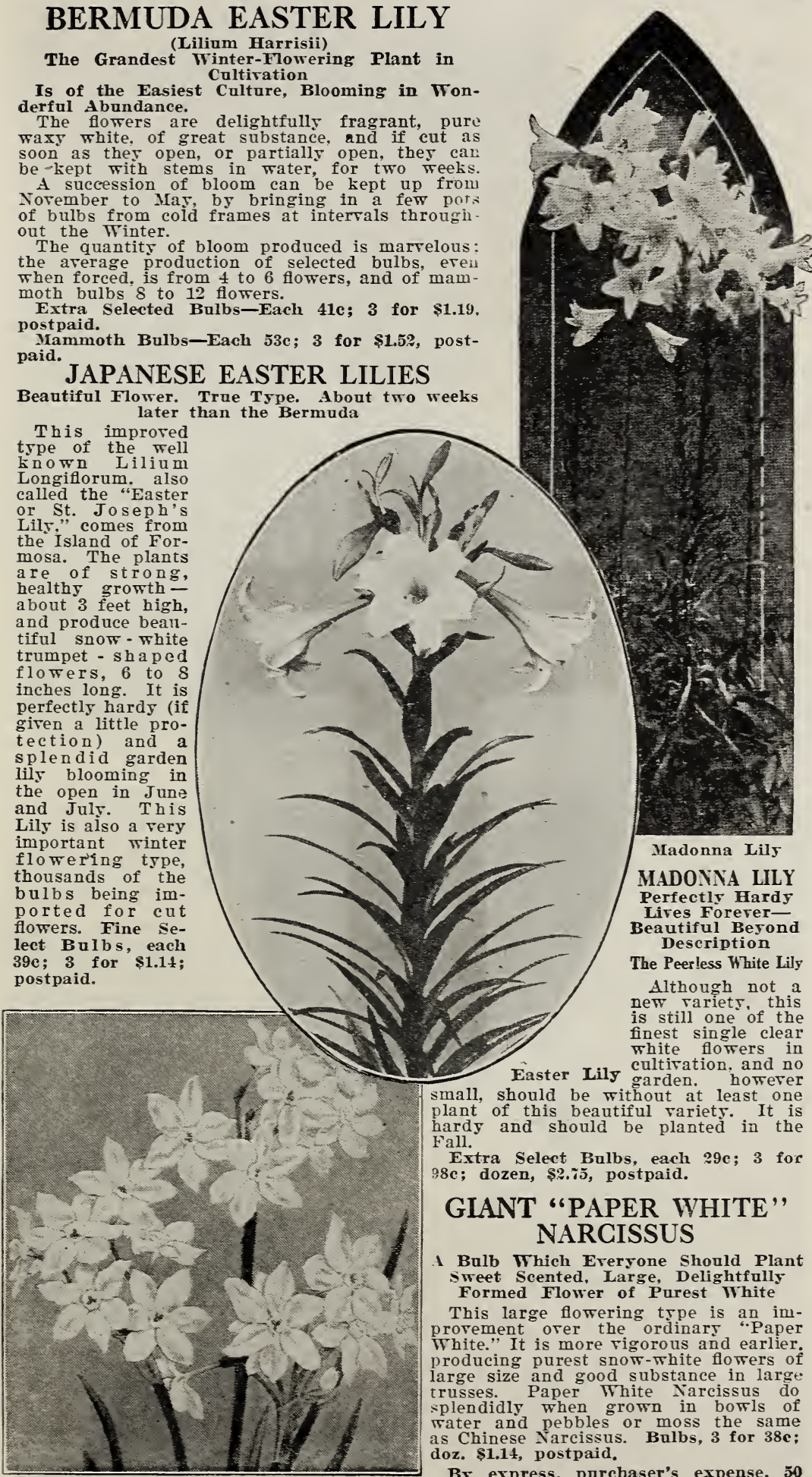

garden. however hardy and should be planted in the Fall

Extra Select Bulbs, each 29c; 3 for 98c; dozen, \$2.75, postpaid.

\section{GIANT "PAPER WHITE" NARGISSUS}

A Bulb Which Ereryone Should Plant sweet Scented, Large, Delightfully Formed Flower of Purest White

This large flowering trpe is an improvement orer the ordinary "Paper White." It is more vigorous and earlier. producing purest snow-white flowers of large size and good substance in large trusses. Paper White Narcissus do splendidly when grown in bowls of water and pebbles or moss the same as Chinese Narcissus. Bulbs, 3 for $38 \mathrm{c}$; doz. \$1.14, postpaid.

By express, purchaser's expense, 50 


\section{Beautiful Chinese Sacred . Lilies}

A Charming Plant; Easily Grown in Water

The most popular of the Home Flowers. If planted early will bloom by Christmas.

The Chinese Lilies are usually grown in bowls or dishes of water. Put an inch or two of sand and gravel in the dish in which they are to be grown, set the bulbs on this and put enough pebbles around them to keep them from falling over; then fill the dish with water and set in a dark place for a few days, bring them to the light when the roots have started freely.

Large Bulbs - each $24 \mathrm{c}$; 3 for $69 \mathrm{c}$; doz. \$2.25, postpaid.

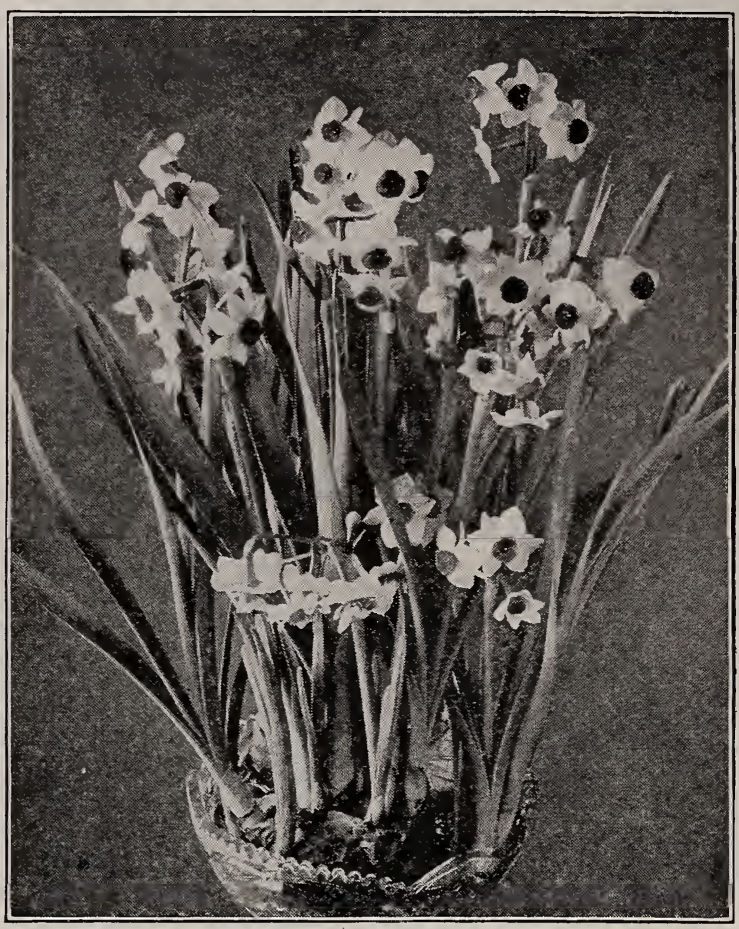

Chinese Sacred Lily

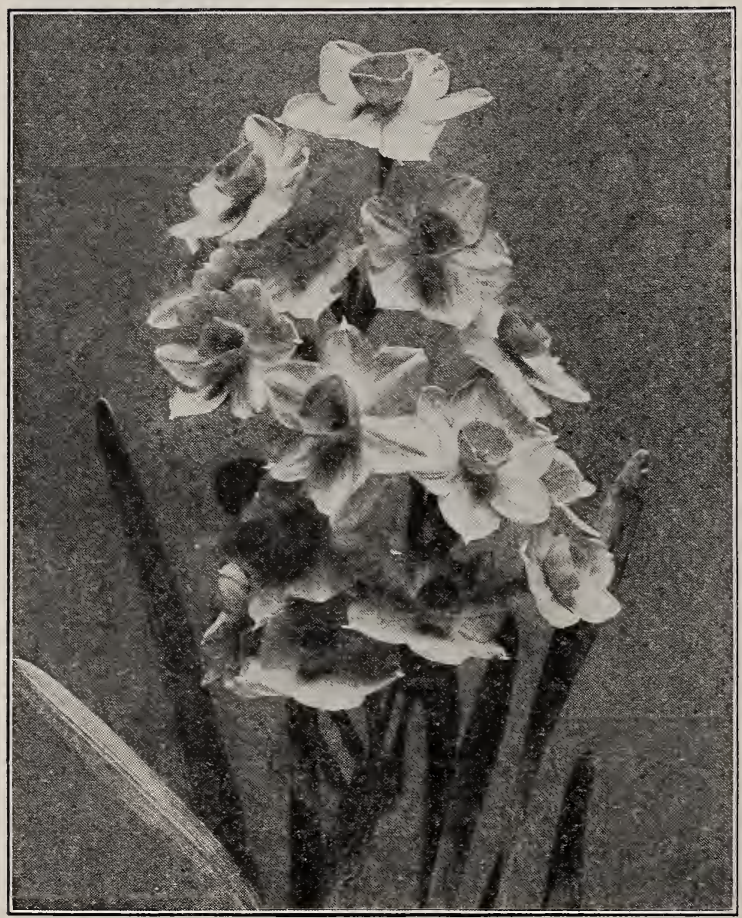

Polyanthus Narcissus

\section{Buckbee's Polyanthus Narcissus}

Very Sweet Scented. Exceedingly Beautiful

The Polyanthus varieties of Narcissus are not only beautiful but deliciously sweetscented, and of the easiest culture; very free-flowering and suitable for window garden, conservatory or garden, continuing long in bloom, bearing from six to twenty-four flowers each. The pure white petals and gold cups of some varieties, the yellow with deep orange cups of others and the self whites and yellows render them great favorites. These are considered the best of all Narcissus for pot culture, and by many esteemed the most beautiful. Choicest mixed colors-2 for $34 \mathrm{c}$; doz. $\$ 1.49$, postpaid.

By express, purchaser's expense, 50 for $\$ 5.46$. 


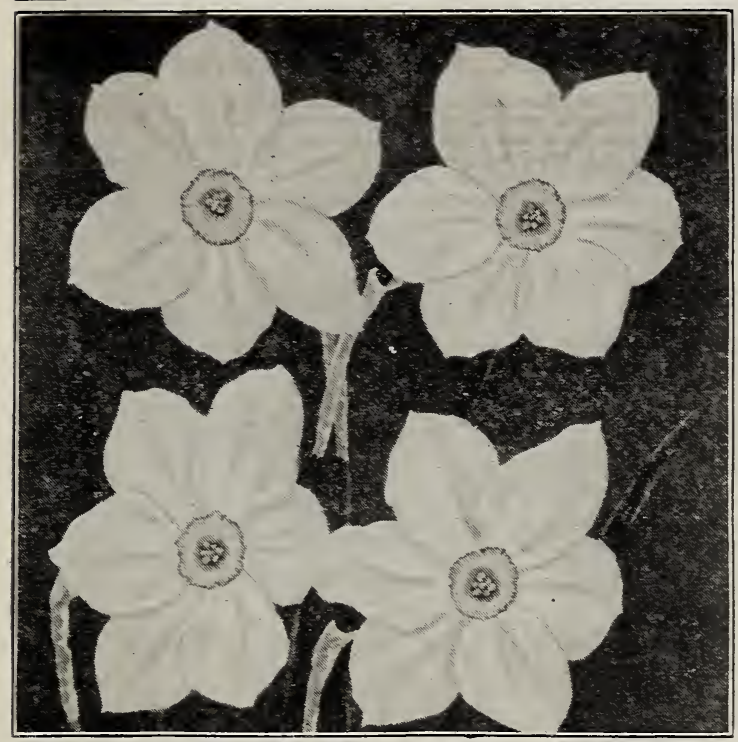

\section{POETS NARCISSUS}

Tell known and loved by all. Exquisite garden flowers, set equally raluable for winter blooming in pots.

Poeticus-King Edward -Excellent for outside work. Single pure Whit e, orange cup hards, 2 for 31e; doz, $\$ 1.32 ; 100$ for $\$ 9.24$.

Poeticus-Majestic-Very popular early rariety. 3 for $36 \mathrm{c}$; doz. $\$ 1.08$; 100 for $\$ \% .49$.

The seeds and plants which I ordered from you were just fine. I had the nicest garden in the neighborhood. It was because I used Buckbee's "Full of Life" seeds and plants.

Urs. P. J. Watson, Murphysboro, İl.

\section{GOLDEN FAIRY LILY}

Narcissus-Hoop-Petticoat

A rarels beautiful flower, both for winter blooming in the house or for the garden. Three to six bulbs can be planted in an ordinary pot and will produce a charming lot of flowers during February and March. Each bulb bears 3 or 4 flowers at a time. As will be seen by the cut the blossoms are very beautiful in both form and habit; color a fine shade of bright brilliant $\boldsymbol{y}$ ellow, and fragrant. In the garden they are hardy and bloom earls in the spring. Price, 2 for $34 c$; dox. $\$ 1.50 ; 50$ for $\$ 5.46$.

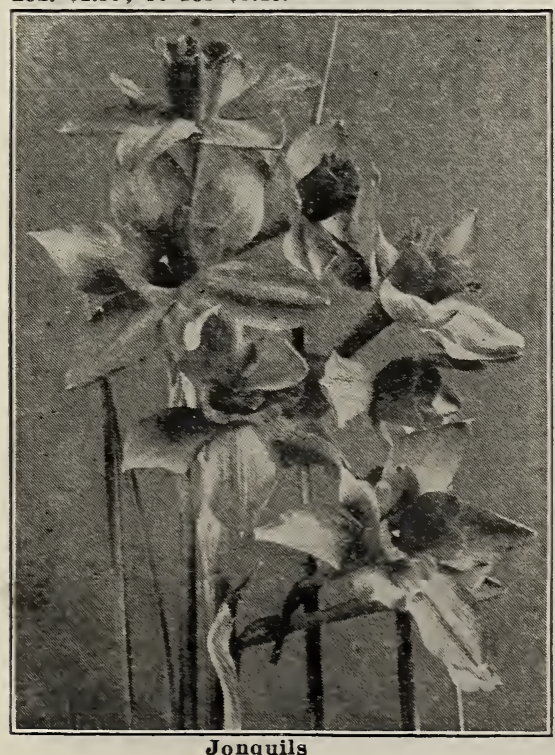

Jonquils

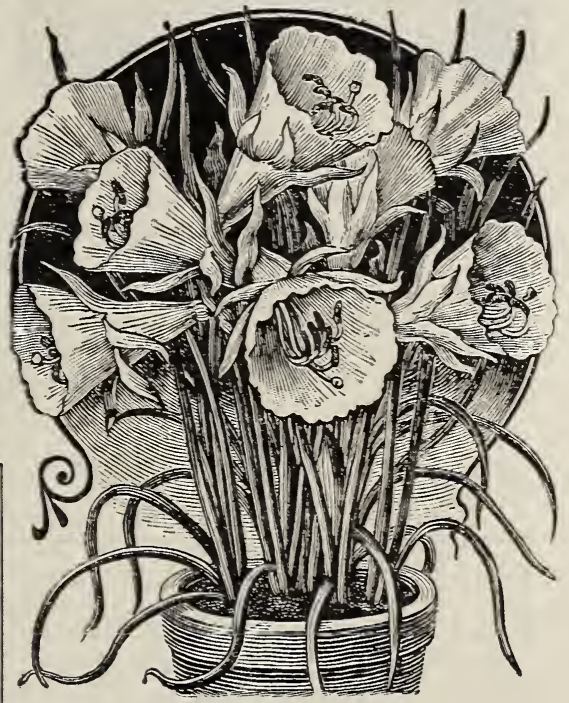

Golden Fairs Lily

JONQUILS

Sometimes Called "The Miniature Yarcissus"

These dainty flowers are a gleam of gold when in bloom and large clumps or masses of them are alwass admired. Thes are extra fine for pots. from their beautiful color, profusion and delightful fragrance and thes flower rery early in the window. In the garden thes are perfectly hardy, and their lorely blossoms appear almost as soon as Crocus.

Sweet Scented-3 for 42c; doz. \$1.24; 50 for $\$ 4.67$.

YoTICE-12 bulbs or less sent postpaid; larger quantities by express, collect. 


\section{NARCISSUS OR DAFFODILS}

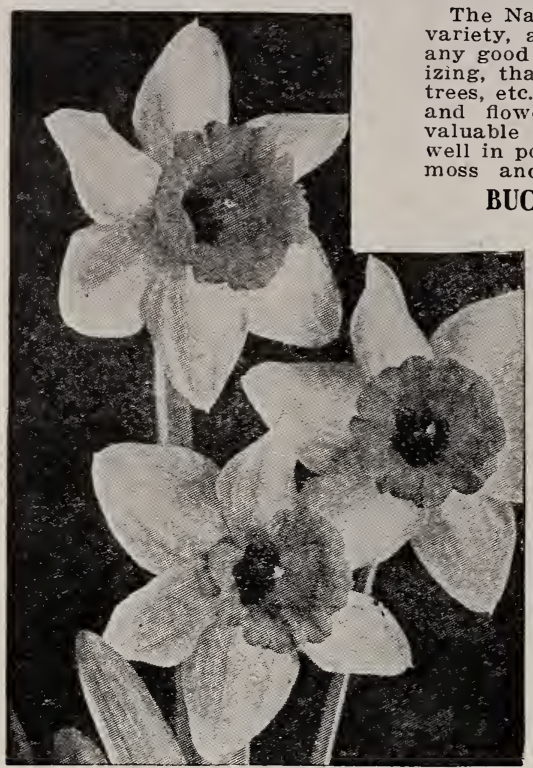

Conspicuous

GLORY OF SASSENHEIM-One of the earliest of the daffodils and an unusually pretty variety. Very large flowers with pure white perianth and golden yellow trumpet. 2 for 38c; doz. $\$ 1.71 ; 50$ for $\$ 6.24$.

GOLDEN SPUR-A solid color flower-early and desirable. Both trumpet and outer petals are of a rich golden yellow color, which lasts well on the plant or in water. 2 for 35c; doz. $\$ 1.47 ; 50$ for $\$ 5.4 \%$.

MRS. LANGTRY -A fragrant variety with very short trumpet. Blooms freely. Flowers are pure white with a primrose yellow cup with
darker edge. 3 for $43 \mathrm{c} ;$ doz. $\$ 1.28 ; 50$ for $\$ 4.75$. SIR WATKIN-A gigantic flower, 4 to 5 inches across, with broad, wing-like petals that shade from canary jellow at the tips to a golden yellow base. 2 for $30 c$; doz. $\$ 1.34 ; 50$ for $\$ 4.97$.

BUCKBEE'S “FULL OF LIFE" SINGLE MIXED -The best assortment ever offered. All colors and varieties. 3 for $30 \mathrm{c}$; doz. $91 \mathrm{c} ; 50$ for $\$ 3.56$.

\section{GOLDEN WATER LILY}

The very newest and best flower. Similar except in color to the Paper White Narcissus shown on page 13, and grown in the same manner. Flowers rich golden yellow. Bulbs, each 26e; 3 for 7ic; doz. \$2.14, postpaid.

Prices on Single Bulbs and Dozens postpaid; larger quantities by express not prepaid. Send your order today which is usually early in Septemher.

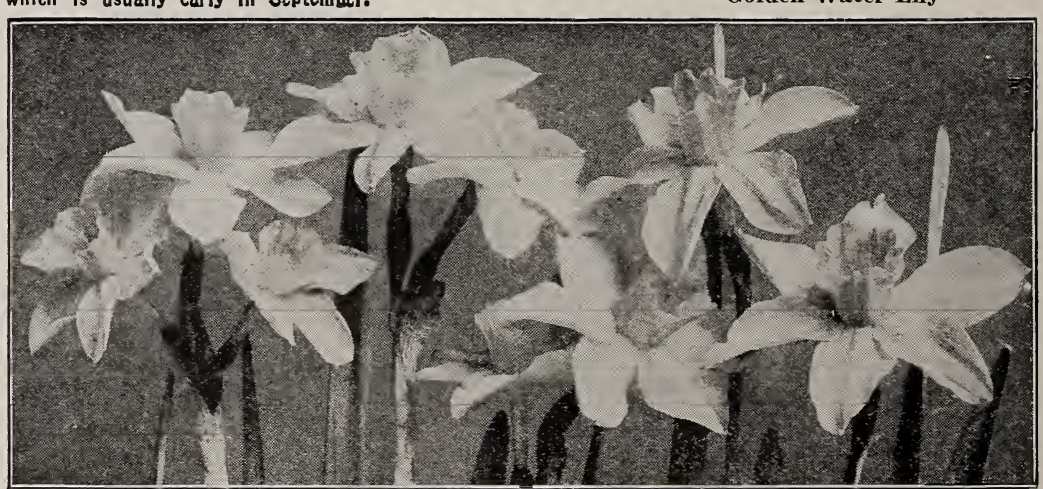

S NEW AND UNEQUALED NARCISSUS THE BEST SINGLE VARIETIES Culture

The airy grace and refined beauty of the ngle Narcissus has no superior and few orms are color harmonious and refined.

NaNPICCOUS - A variety of Star Narcissus with long wiry stems. Light yelyellow cup with orange scarlet edge. Very popular and a good grower. Admirably suited for planting in masses. 3 for $42 \mathrm{c}$; doz. $\$ 1.24 ; 50$ for $\$ 4.63$.

wellow trumpet with perianth of deep crimson. Long and the blossoms large. 2 for $34 \mathrm{c}$; doz. $\$ 1.48 ; 50$ for $\$ 5.48$.

MPRESS-This possesses the same gigantic size and form of the Emperor but is a bi-color flower with golden trumpet and 50 for $\$ 5.46$

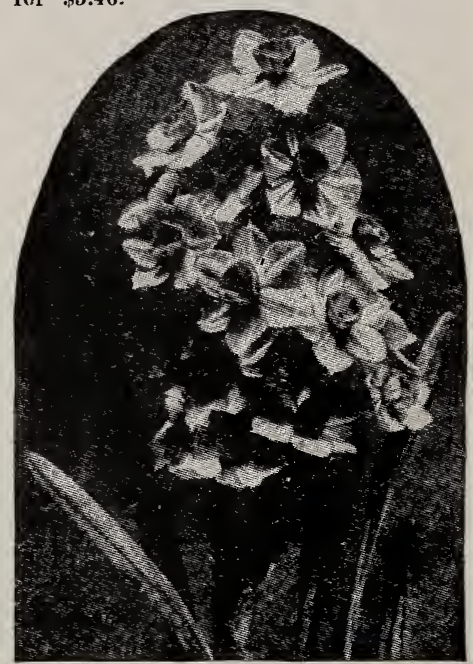

Golden Water Lily 


\section{NARCISSUS OR DAFFODILS}

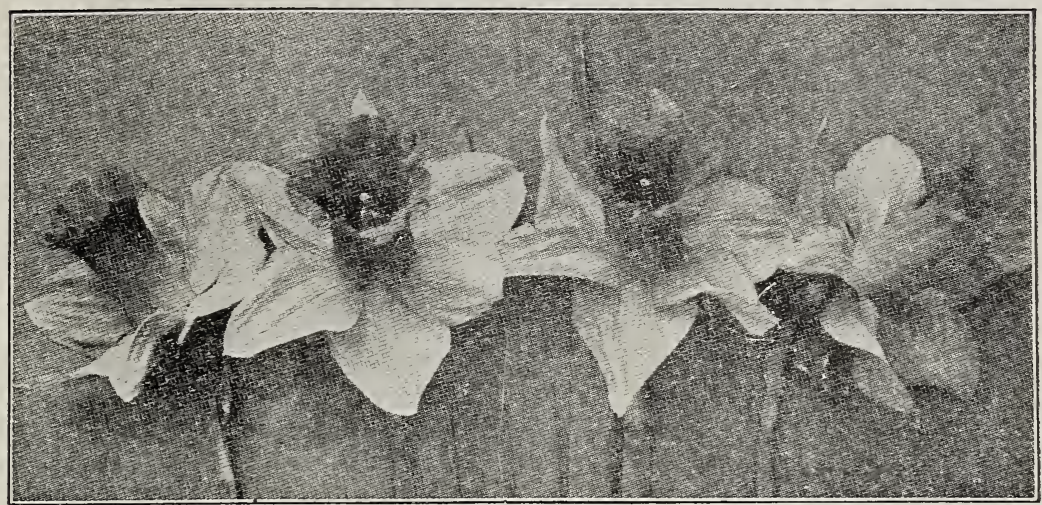

\section{NEW NARCISSUS-KING ALFRED}

The King of the Single Yellow Daffodils

Tall, strong growing, golden yellow flower of beautiful appearance. The largest of all. Trumpet and Perianth of the same beautiful color. Lasts well on the plant and when cut. Price, selected bulbs, each $33 \mathrm{c} ; 3$ for $93 \mathrm{c}$; doz. $\$ 2.79 ; 50$ for $\$ 9.74$.

\section{FOUR NEW AND DESIRABLE NARCISSUS}

Caesar-The best of all the double yellow Narcissus. Flowers are of large size, good for cutting, and the color is that rich golden yellow which is so much admired. Each $19 \mathrm{c} ; 3$ for $50 \mathrm{c}$; doz. \$1.49; 50 for $\$ 5.48$.

Cleopatra-One of the largest and finest. Pure yellow trumpet of immense size and wide overlapping, rich primrose perianth. Each $20 \mathrm{c} ; 3$ for $55 \mathrm{c} ;$ doz. $\$ 1.64 ; 50$ for $\$ 5.94$.

Eastern Maid-A gigantic flower, probably the largest of all. Outer petals sulphur yellow, cup slightly deeper in color and tinged with orange. Always pleases. Each $23 \mathrm{c} ; 3$ for $62 \mathrm{c} ; \mathrm{doz} . \$ 1.85 ; 50$ for $\$ 6.73$. Pharoah-A bi-color variety having a perianth of creamy yellow, with a rich yellow trumpet. The sweetest scented of any of the Narcissus. Each $18 \mathrm{c} ; 3$ for $48 \mathrm{c} ; \mathrm{doz}$. $\$ 1.43 ; 50$ for $\$ 5.26$.

\section{BUCKBEE'S "FULL OF LIFE" DOUBLE NARCISSUS or DAFFODILS}

Of late years the Double Narcissus have been becoming more and more popular until now with the straight colors and bi-colors they are an ormament anywhere. Double Flowering Daffodils are hards and especially adapted for open-ground planting, where under congenial conditions they thrive and increase for years. The early sorts are also useful for pot culture and winter forcing.

Twelve Bulbs or less sent postpaid; larger quantities by Express, collect.

Buckbee's New Aurora-The most brilliantly colored of all the Double Narcissus. Plants are of sturdy erect growth, bearing an abundance of bright golden yellow flowers. Trumpet is long and extremely double. Price, select bulbs, 21c each; 3 for $57 \mathrm{c}$; doz. $\$ 1.71 ; 50$ for $\$ 6.24$.

Von Sion-Single starlike petals and long double trumpet filled with beautifully crimped petals. Color rich golden yellow. Price, select bulbs, 2 for $30 c$; doz $\$ 1.35 ; 50$ for $\$ 4.9 \%$.

Crystal White-Pure white, very double and extremely sweet-scented. Price, select bulbs, 2 for 29 c; doz. $\$ 1.28 ; 50$ for $\$ 4.73$.

Orange Phoenix-Nearly pure white outer petals. Center well filled with mixed white and deep orange petals. Price, select bulbs, each 21c; 3 for 56c; doz. \$1.68: 50 for $\$ 6.13$.

Buckbee's "Full of Life" Double Finest Mixed-Made up from the finest of the large double sorts. Price, select bulbs, 6 for 51c; doz. 98c; 50 for $\$ 3.68$.

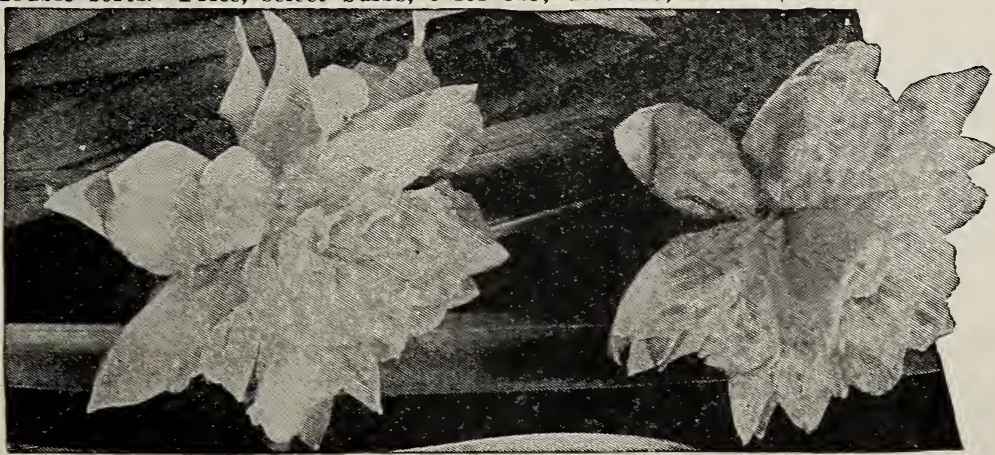

Buckbee's New Aurora Narcissus 


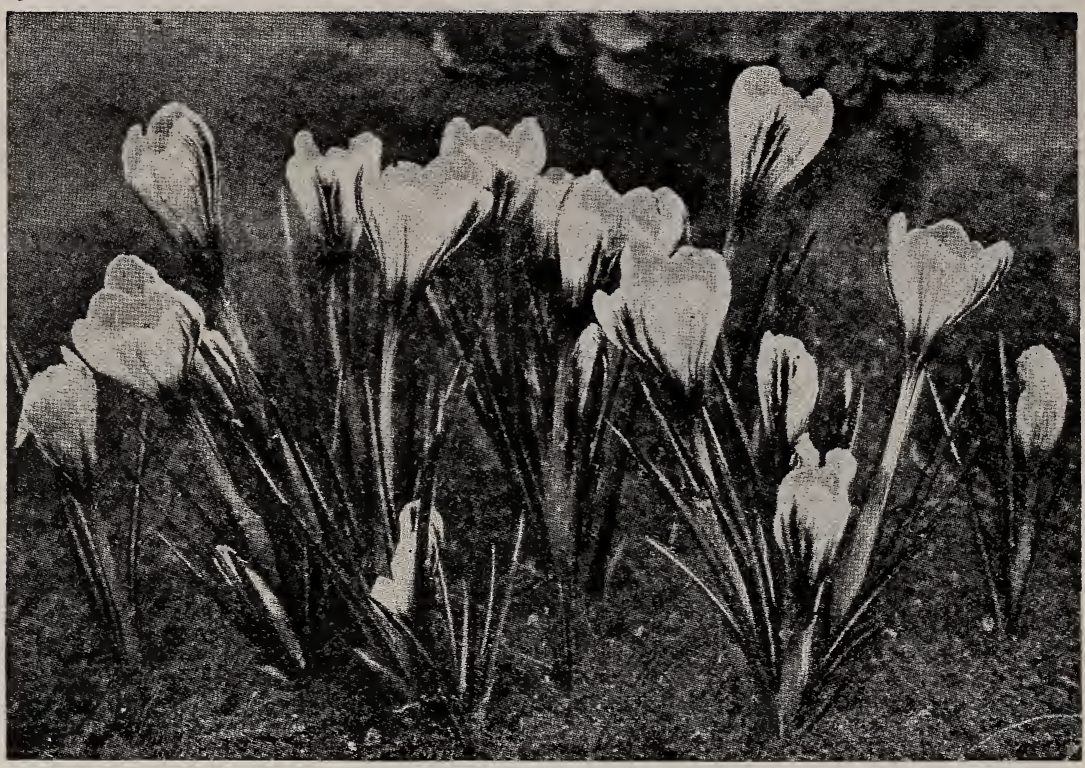

Buckbee's Giant Croeus

\section{BUCKBEE'S GIANT GROCUS}

These are large bulbs of the best varieties, and are remarkable for richness of color and size of their flowers, and are best to use for pot culture where extra fine results are wanted.

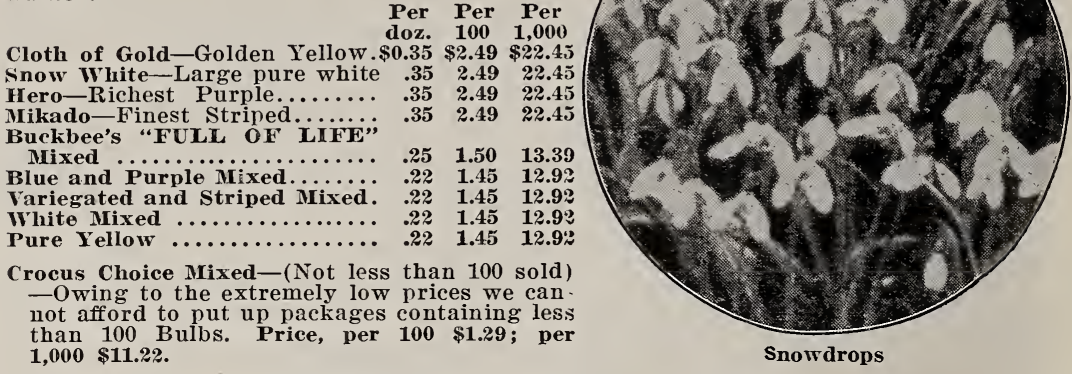

\section{BUCKBEE'S "FULL OF LIFE" WINTER-BLOOMING FREESIAS}

A new class of bulbs, splendidly adapted to winter blooming in the window. They are always sure to succeed and bloom elegantly for anyone in any situation, and the great beauty and fragrance of the flowers are everywhere admired. The blossoms or buds when cut and placed in vases of water will keep perfect two weeks. In pots they commence blooming early and continue for a long time.

The Bride-Flowers of enormous size, with thick, heavy, waxy petals. Flowers pure snow white, save one tiny yellow spot in throat, and of wonderfully beautiful shape. 3 for $19 \mathrm{c} ; 12$ for $55 \mathrm{c} ; 100$ for $\$ 3.72$, postpaid.

Purity-Large sprays of purest snow-white flowers of immense size which are deliciously fragrant. The foliage is narrower and less coarse than that of ordinars strains. 6 for $18 \mathrm{c}$; doz. $30 \mathrm{c} ; 100$ for $\$ 1.97$, postpaid.

New Rainbow Hybrids-The wonderful colors are not equaled in any other flower. The flowers are carried on long, stout stems and run through many delicate ani artistic shades, all of which are very sweet scented. Mixed colors, 3 for 20c; doz. 59c; 100 for $\$ 3.99$, postpaid.

\section{BUCKBEE'S BEAUTIFUL SNOWDROPS}

\section{The Earliest Spring Blooming Flower}

This is the earliest of all spring-flowering bulbs. In a warm sunny border the flowers will come through the ground as early as March, long before all of the snow is gone. The bulbs do best planted in masses in a moist, cool and shady place, and they will increase rapidly with every year; but they do well in almost any kind of soil and can stand harder treatment than most other bulbs. Price, 3 for 17c; doz. 50c; 100 for $\$ 3.48$. 
One of the most beautiful and satisfactory flowers for house culture.

Alba Picta-Glossy green spotted leaves; silver-white flowers. Each 19c.

New Beefsteak-Thick rounded leaves of deep green with red on the reverse side. Each 29c.

Otto Hacker-Shining deep green leaves. Flowers bright coral-red. Each 27c.

Robusta-The stem and under side of the leaf are indian-red; upper side glossy olive-green. Buds coral-red. Each 21c.

Rubra-Dark green leaves with scarlet rose flowers. Each 23c.

Speckled Beauty-Leaves are pure bronze-color with silver markings. Blooms easily. Large trusses of snow white flowers. Each 31c.

Thurstonii-Foliage bright green shading to red; flowers rosy white. Each 24 c.

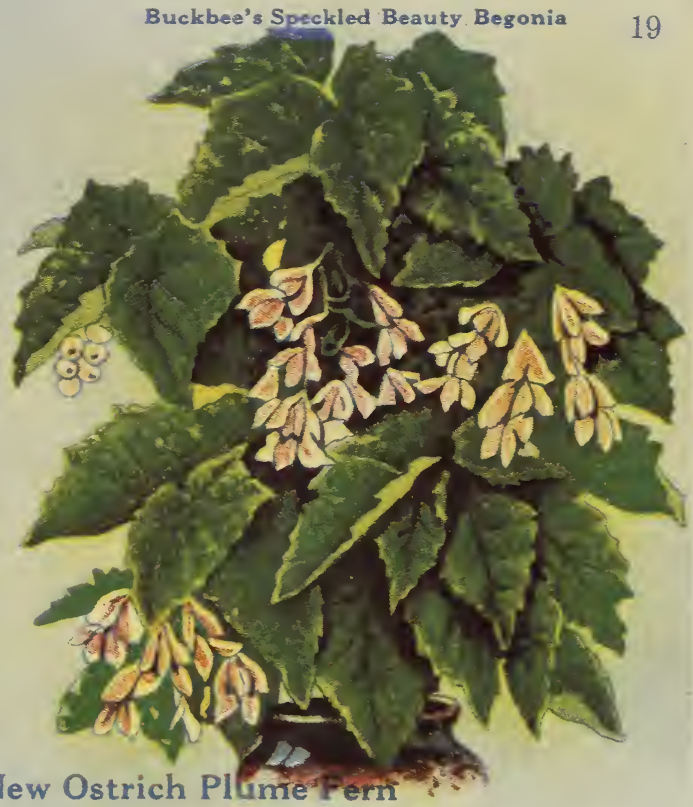

Buckbee's New Ostrich PlimetPern :

The Showiest And Easiest Growing Fern

A strong, vigorous grower, but the fronds are heavy and feathery, and arch over in a most graceful manner, showing two shades of green and producing a lovely mossy effect, which adds greatly to its beauty. Fine young plants $30 \mathrm{c}, 40 \mathrm{c}$ and $50 \mathrm{c}$ each, postpaid. Larger plants $\$ 1.00, \$ 2.00$ and $\$ 3.00$ each, by express, not prepaid.

\section{Buckbee's New Baby's Breath Fern}

The Daintiest Fern Ever Grown. Strong, vigorous Grower and Unequaled as a House Plant. This is the only fern that is equally beautiful when small and when it has reached its full growth. The leaves are extremely fluffy, giving a ruffed appearance, while the individual fronds are so dainty and delicate as to suggest its name, "Baby's Breath"; still it is as hardy and vigorous and as easy to grow as any house fern we have. Choice young plants $36 \mathrm{c}$ each; 3 for $99 \mathrm{c}$, postpaid.

\section{Weeping Lantana}

Mrs. McKinley-A fine plant, of graceful, drooping habit, producing flowers at each leaf-joint. The flowers are a brilliant rosy lilac, borne in elegant clusters, and hundreds of them are in bloom all the time and literally cover the whole plant. One of the best varieties for hanging baskets. Each $24 \mathrm{c} ; 3$ for 69 c, postpaid.

\section{Everblooming Lantanas}

The Set of 4 Everblooming Lantanas, 72c Postpaid Showy plants that bloom continually. Flowers are small, bright eyed and very beautiful. Aurora-Large flowered; shades of pink, yellow center. Each 18c, postpaid. Perfection-Rich velvety crimson-wine color; center of blood orange. Each 22c, postpaid. Radiation-Brilliant scarlet orange, yellow center. Each 21 , postpaid.

Snowstorm-Pure white sood size and very attractive. Each 19c, postpaid.

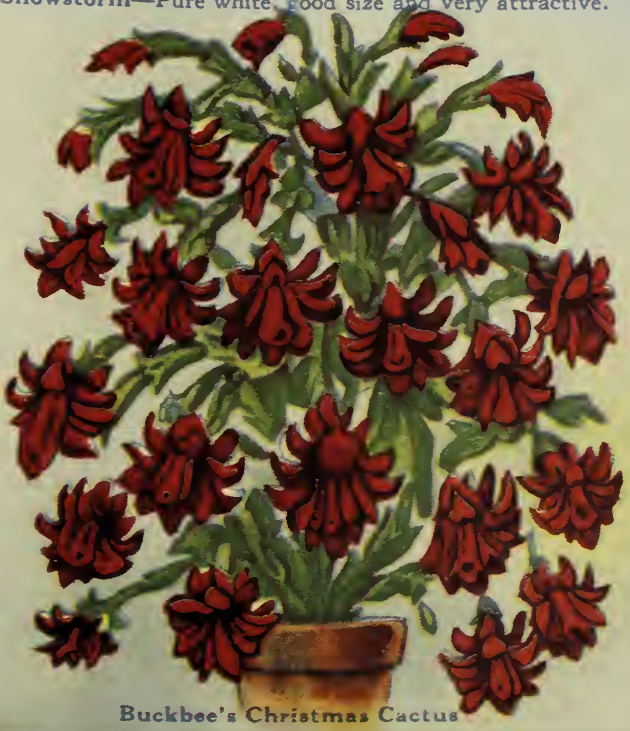

Buckbee's Christmas Cactus

The Beautiful Decorative Christmas Plant

Scarlet Flowers and Green Foliage. Easy to Grow and Sure to Bloom. A

Wonderfully Attractive Novelty.

This wonderful plant of our own introduction blossoms very early and is usually in wonderful shape for Christmas and the holidays. It is a very unusual appearing plant as will be seen by the illustration. It is an early flowering crimson scarlet variety, with long drooping flowers, borne in great profusion. Stems branching and hanging in bunches. It grows and blooms with the greatest ease, requires absolutely no care, living for months without water, increasing in value yearly. Fine plants, 31c each; 3 for $87 c$, postpaid. 


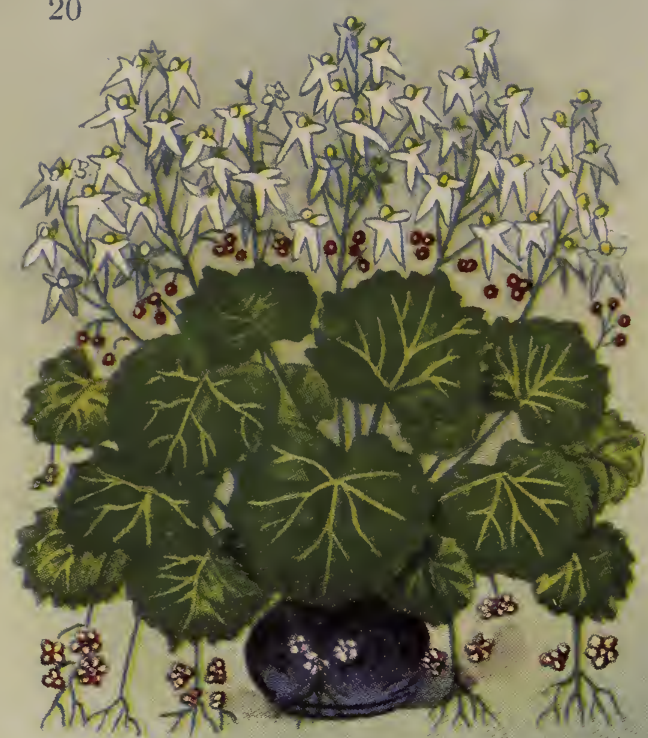

\section{Buckbee's New Strawberry Geranium}

Easy to Grow-Sure to Bloom.

A Gem of Many Colors.

This is another novelty of unusual merit combining rare grace and beauty with ease of culture and general use. fulness. One of the handsomest plants imaginable, a gem of many colors, exceedingly rare and beautiful. Leaves nearly round, and striped freely with silver bands; bloom white, of great beauty and borne in spikes nearly 12 inches high; of easicst growth. Adapted for hanging baskets, vases, etc. Will stand more neglect and mistreatment than almost any house plant, but will repay any care and attention by giving better growth and brighter-colored foliage. This is the most wonderful Geranium ever grown, and all who have seen one in bloom, admit it is the prettiest plant they have ever seen.

Each $26 \mathrm{c} ; 3$ for $73 c$, postpaid.

Buckbee's Strawberry Geranium

\section{The Australian Silk Tree}

A magnificient plant for decorative purposes, of rapid easy growth, finely cut foliage. The young growing leaves are a light brown color, the tips being covered with a soft down, closely resembling raw silk, hence the name, "Silk Tree". Each $23 \mathrm{c} ; 3$ for $66 \mathrm{c}$, postpaid.

\section{Brazilian Plume Plant}

A native of Brazil. It is a strong, rapid grower, and throws long shoots, each of which is tipped with beautiful pink, plume-like flowers, the ends of every petal drooping in a most charming manner. It is a grand pot plant, commencing to flower when the plants are very small, and blooming profusely for several months out of the year. Each $26 \mathrm{c}$; 3 for $73 \mathrm{c}$, postpaid.

\section{Crown of Thorns}

Very peculiar, thorny, with a few bright green leaves and an abundance of light rose blossoms. Easy to grow, can be trained to assume any desired shape. Fine plants, each $29 \mathrm{c} ; 3$ for $83 \mathrm{c}$, postpaid.

\section{Royal Purple Plant}

Strobilanthes-The leaves are beautifully variegated, with a deep metallic purple, shaded with dark rose and margined light green. Grown as a pot plant in the house it is very bright and effective. Each $29 \mathrm{c} ; 3$ for $85 \mathrm{c}$, postpaid.

\section{Swan Flower (Swainsonia)}

Alba-This is a very beautiful plant, both for flower bed and house culture; flowers are pure, snowy white, and borne in pretty sprays all over the plant. Price, $25 \mathrm{c} \mathrm{each;} 3$ for $70 \mathrm{c}$, postpaid.

Rosea-Same as Alba except in color, which is bright, rich, rosy red. Very choice and rare Price,

30 c each; 3 for $85 c$, postpaid.

\section{New Fuchsias-Carmeliata}

Large Double White Flowers of Great Beauty

Fuchsias have always been a popular flower and we are always trying to get something a little better for our friends and customers and now have a Fuchsia which blooms with greatest profusion during the winter, is scarcely ever without flowers from September till June, the flowers are large and of the most graceful form; most charming window plant, remarkable for its bright glossy green leaves and constant profusion of exquisitely beautiful flowers. Undoubtedly the finest Double White Fuchsia ever sent out; makes a neat compact plant, branches freely and is covered nearly all of the time with exquisite large flowers, having brilliant deep scarlet sepais and a corolla of pure snowy whiteness.

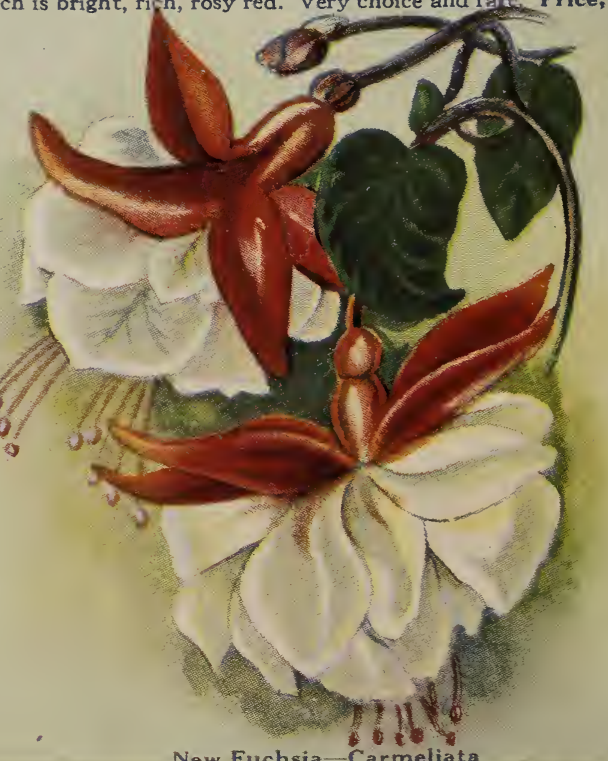




\section{The New \\ Pansy Geranium \\ Beautifully Colored, \\ Flowers all Winter}

One of the most beautiful blooming plants; they offer a rich and varied assortment of colors; easily grown. A grand house plant of easiest growth, dwarf habit, and literally covered with flowers all the time, and as it requires little or no attention it is invaluable as a window plant. Considered by many to be the finest pot plant in cultivation. Habit strong, compact and bushy, with the strongest constitution and great wealth of beautiful luxuriant foliage. The plants are perpetual in blooming habit, especially from March to September. The petals beautifully curved and cupped and borne in endless profusion. The colorings and markings of the flowers are most extraordinary-light pink, white, dark purple, black, etc., almost rivaling the Pansy in uniqueness of coloring. It is this combination of coloring which obtained for it the popular name of Pansy Geranium.

Strong plants ready to bloom, 34c each; 3 for $99 c$, postpaid.

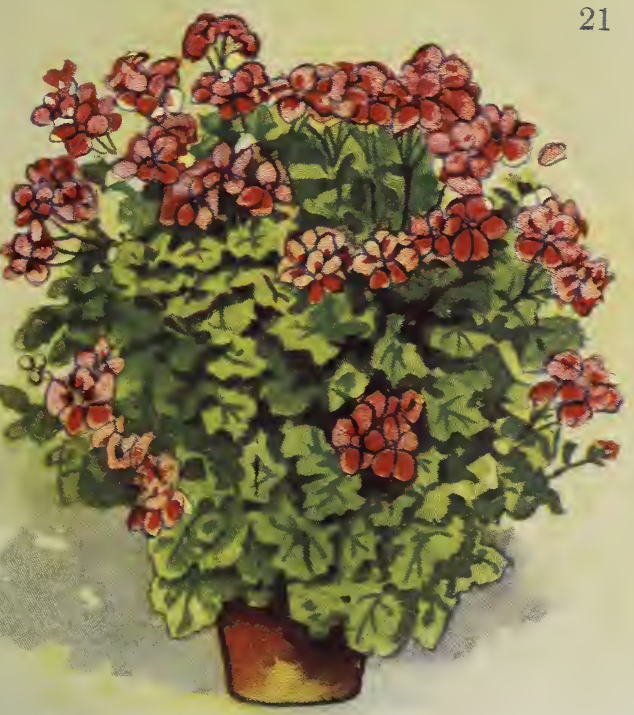

The Pansy Geranium

\section{Buckbee's Baby Rambler Roses}

Equally Beautiful in Pots or Out of Doors

Crimson Baby Rambler-It is equally valuable as a pot or garden Rose, and blooms profusely Summer and Winter, Spring and Fall. Freshly rooted cutting plants when only a few inches high begin to bear most beautiful clusters of bloom. Fine plants, postpaid, each $26 \mathrm{c} ; 3 \mathrm{for} 68 \mathrm{c}$. Large two-year-old plants, each $59 \mathrm{c}$.

White Baby Rambler - This does not differ from the above except in color, which is purest snow white. Fine plants, postpaid, each $24 \mathrm{c} ; 3$ for $66 \mathrm{c}$. Large two-year-old plants, each $58 \mathrm{c}$.

Pink Baby Rambler-Flowers cerise pink, center chrome yellow. Fine plants, each 24c; 3 for $66 \mathrm{c}$. Large two-year-old plants, each $58 \mathrm{c}$, postpaid.

\section{Hardy Hybrid Perpetual Roses}

American Beauty-A rich shaded crimson.

Clio - Flesh color with a rosy pink center.

General Jacqueminot-Shining crimson.

Paul Neyron-Deep, shining rose.

Prince Camille de Rohan-Velvety crimson.

Ball of Snow-White flushed with rose.

Frau Karl Drusky - The best pure white.

Jubilee-Fragrant cherry red.

Special PRICE-Strong plants, postpaid, each 29c; 3 for 83 c. Large two-year-old Roses, each $64 \mathrm{c}$.

Climbing American Beauty-Dark Crimson.

\section{Climbing Varieties of Hardy Roses}

Excelsa or Red Dorothy Perkins-Crimson scarlet.

Improved Crimson Rambler-Rich crimson.

Improved Yellow Rambler-Saffron yellow.

Tausendschon or 1000 Beauties-Colors white to pink.

White Dorothy-Pure white.

SPECIAL PRICE-Strong plants, postpaid, each 21c; 3 for 54c. Large two-year-old plants, each $51 \mathrm{c}$.

\section{Golden Emblem Rose}

$$
\text { A True Golden Yellow Color }
$$

The Finest Rose for Winter Blooming in the House That Was Ever Grown

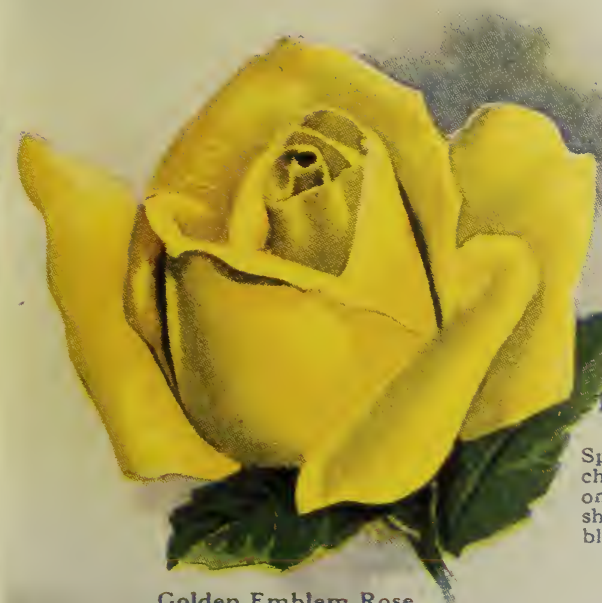

This new Rose is the most beautiful plant we have ever seen. When in bloom it surpasses the Marechal Neil both in its beautiful shape and wonderful color which is rich, deep golden yellow; the best and most satisfactory yellow ever seen in a Rose. In bloom constantly, being perpetual flowering. The flowers are always large and perfect, making it, we believe, the most striking and remarkable Rose known today. Strong plants, each $34 \mathrm{c}$; large two-year-old plants, each $73 \mathrm{c}$. New Rose Violet Blue (Veilchenblau)

This Rose blooms abundantly for us every Spring and Summer, a rosy lilac when opening. changing to amethyst or metallic blue. No one need doubt that it is real blue - on the-violet shade. Grows vigorously, like Crimson Rambler, blooming annually in abundant clusters.

Strong plants, each $28 c ; 3$ for $79 c$; postpaid. 


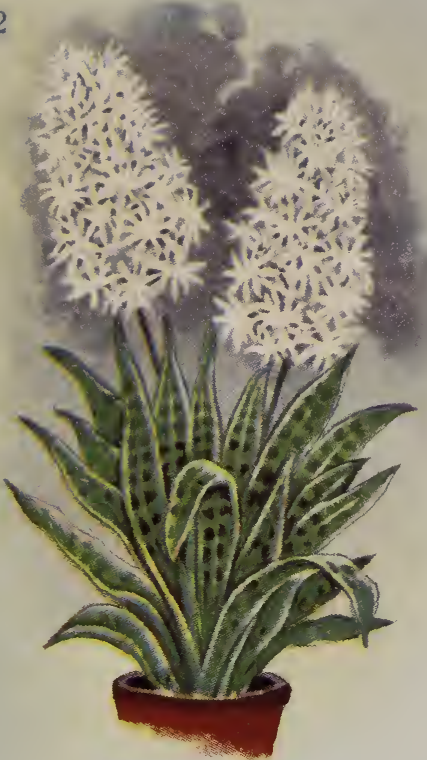

Assyrian Leopard Plant

\section{Buckbee's Assyrian Leopard Plant}

The Iron-Clad House Plant. Rigid Sword-Like Leaves of Green, Barred with Creamy White.

This wonderful novelty which originated in Asshur (Assyria) is a beautiful decorative plant which will stand any amount of neglect and should be grown for positions where other plants do not thrive. It will grow where nothing else does, in a sunless window, a dark hall, a cool bedroom or stand on the mantle in a heated room. It will stand gas and dust, and will go for months without a drop of water, yet remain as thrifty as ever. Singularly beautiful, as well as easily grown. Erect, rigid, sword-Fike leaves which are thick and fleshy, a dark green color, with clouded bars of white. Fine plants postpaid, $36 \mathrm{c}$ each; 3 for $97 \mathrm{c}$. Larger plants, by express not prepaid, $99 \mathrm{c}$ to $\$ 1.49$ each.

\section{Umbrella Palm}

A very decorative palm. Hardy, useful and beautiful window plant for all seasons, always fresh, green and attractive. Invaluable as an aquatic plant. Stems 2 to 3 feet high surmounted by whorls of leaves. Price, 19c each, or 3 for 54 c, postpaid.

\section{India Rubber Plant}

The India Rubber Plant is unequalled for the table and house decoration. It has large, thick, olive green leaves and graceful polished stems. Will stand much more neglect than most plants. By express, not prepaid, fine plants, $75 \mathrm{c}, 99 \mathrm{c}, \$ 1.47$ and $\$ 1.99$ each.

\section{Buckbee's New Everbearing Ponderosa Lemon}

As easily grown in a pot as a Geranium, produces fruit weighing from one to three pounds each on plants one to two feet high growing in pots. It is everbearing and its fruit is delicious.

Select plants, postpaid, each $24 \mathrm{c}$ to $33 \mathrm{c}$. Extra large plants by express, not prepaid, each $\$ 1.47$ to $\$ 2.48$.

\section{Otaheite Orange}

An extra fine pot plant, with glossy leaves, the true fragrant Orange blooms and abundance of little bright Oranges that will hang on the little bush like balls of gold for six months after they are ripe. Beautiful, graceful and fragrant.

Nice, young, thrifty plants, postpaid, each $23 \mathrm{c}$ to $34 \mathrm{c}$. Extra large plants by express, not prepaid, each $\$ 1.48$.

Quarantine Rulings prevent shipping oranges and lemons to California, Florida, Mississippi.

\section{Buckbee's Watermelon Begonia}

A. Real Novelty and a Plant Seldom Seen-Extremely Ornamental and Decorative.

Excellent for house culture; especially for window decoration. The dry hot air of the living room does not bother it at all and the leaves stay as fresh and attractive as out of doors. A warm, sunny window is the best for this plant, and you will find that it will excite the admiration of all who see it. Of the many plants suitable for table and home decoration nothing has ever equalled the Watermelon Begonia. The leaves are distinctly variegated white and green, thick and waxylike and have the appearance of being powdered with frosted silver. Each $29 c ; 3$ for 84 , postpaid.

\section{Rex or Painted Leaf Begonias}

Rex Begonias are the most beautiful and desirable of decorative foliage plants for house and conservatory culture; they are strong, bushy growers and their grand ornamental leaves are exceedingly beautiful and always greatly admired. The leaves are extra large and the colorings magnificent.

These plants are grown for the great beauty of the foliage, as they make unequalled pot plants. Our collection contains many new and wonderful color combinations and will be sure to please all. Fine young plants, $33 \mathrm{c}$ each; 3 for $96 c$, postpaid.

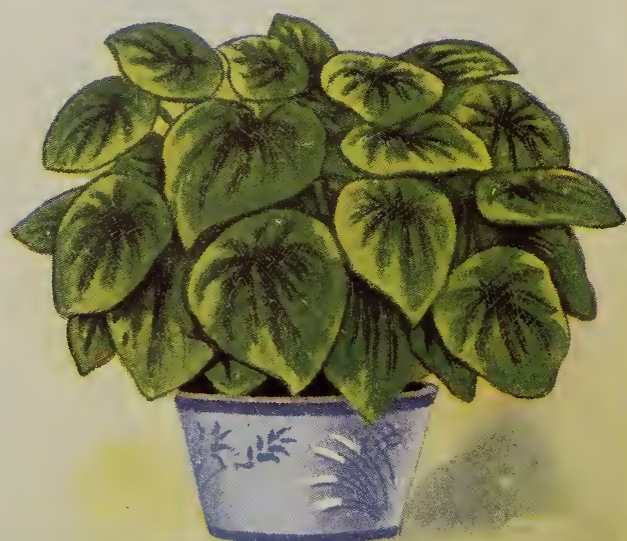

Buckbee's Watermelon Begonia 


\section{BUCKBEE'S "FULL OF LIFE" LILIES}

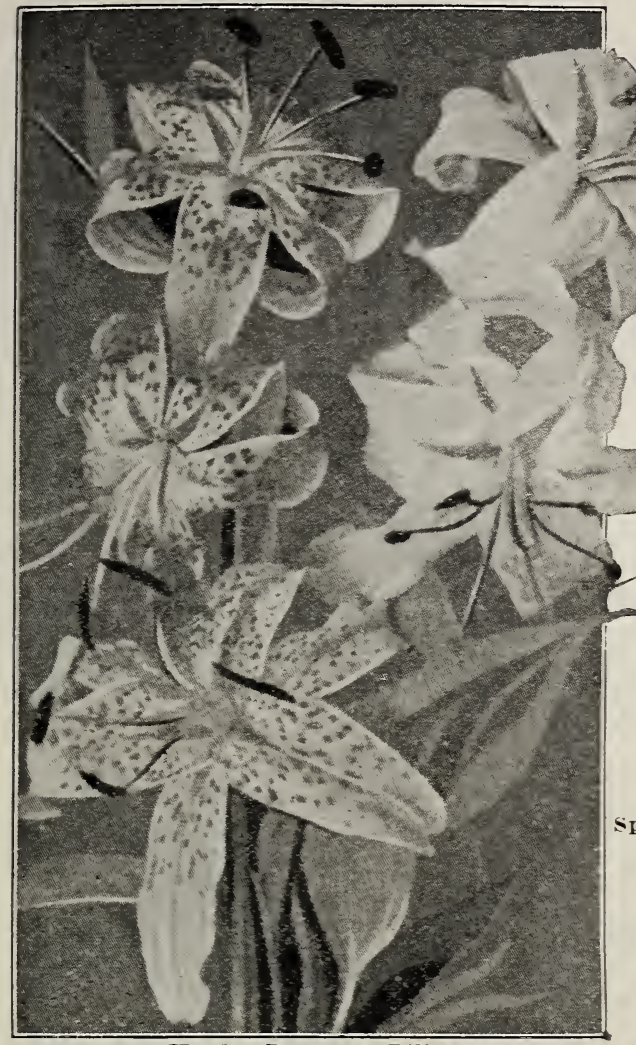

Hardy Japanese Lilies

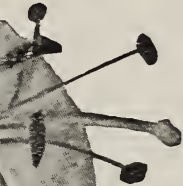

ard

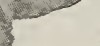
BAXDED LILY

Lilium Auratum-Immense blooms measuring nearly a foot in width when fully expanded are produced in the greatest profusion and are deliciously fragrant. The large white petals are thickly spotted with chocolate-crimson and hare a bright goldensellow band through the center of each. Blooms from July to September. Large Bulbs. Each 39 ; 2 for ric, postpaid.

THE OLIVE BANDED LILY Speciosum Album-Pure white flowers with a greenish band through the center of each petal. They are of great substance and very fragrant. Blooms in August and September. Mammoth Bulbs. Each $38 \mathrm{e}$; 2 for $74 \mathrm{c}$, postpaid. THE RED BANDED LILY

Speciosum Rubrum-No words can overstate the brilliant beauty of these famous Japanese Lilies. The six broad white or pink petals are thickly dotted with rose or crimson spots. and the graceful form and brilliant color make them very effective and desirable. Blooms in August and September. Large Bulbs. Each 3ic; 2 for \%3e, postpaid.

BUCKBEE'S BEAUTIFUL TIGER LILIES

Single-A grand lily sometimes 6 feet high, with large pyramids of orange-red flowers spotted with blact often as many as 20 flowers are counted on one plant. Fery hardy. Splendid Bulbs. Each 21c; 3 for 5ic, postpaid.

Double-This is a plant of stately habit, growing from 4 to 6 feet high, bearing an immense number of double bright orange-red flowers, spotted with black. Blooms in August. Splendid Bulbs. Each 24c; 3 for 69c, postpaid.

\section{BUCKBEE'S HARDY PHLOX}

The Set of 10 for \$2.16, Postpaid No class of hardy Perennials is of more importance than the Phlox which succeed under almost any conditions and flower from the end of June until late in the Fall.

Sensation-Cherry red, suffused salmon.

Mermaid-Light salmon-pink with dark red eye.

Dream-Pure snow white with crimson eye, immense florets and trusses.

Ideal-Pure snow white: gigantic trusses and flowers. The finest white Phlox.

Harmony-A beautiful shade of lavender.

Dawn-Dark rosy pink.

Glitters-Bright crimson.

Brilliance-Carmine rose.

Distinction-Deep salmon-pink with an orange glow.

Marrel-Lavender Cerise.

Prices, any of the abore $24 \mathrm{c}$ each $\$ 2.41$ doz., postpaid.

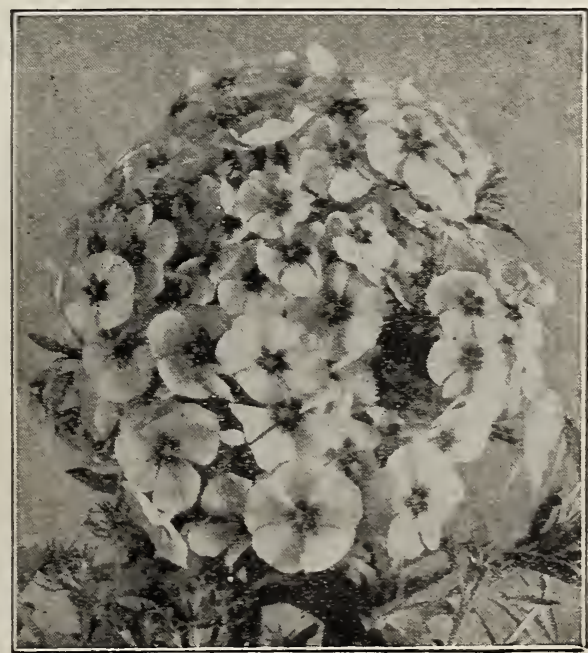

Buckbee's Hardy Phlox 


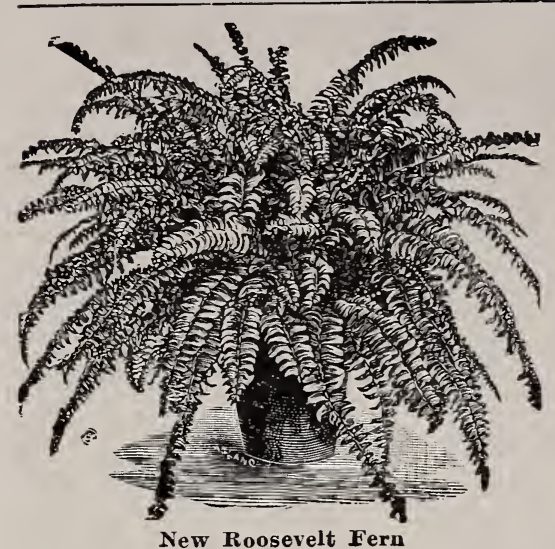

FERNS-Rare

\section{NEW ROOSEVELT FERN}

The Greatest Fern of the Age

In general characteristics it resembles the Boston Fern, but it produces many more fronds, making it a bushier and nandsomer plant; then the pinnae are undulated, giving it a pronounced wavy effect seen in no other fern.

Fine young plants, each 24c, 34c and 44c, postpaid.

Larger plants, each 99c, $\$ 1.99$ and $\$ 2.99$; by express, not prepaid.

THE BOSTON FERN

Nephrolepis Bostoniensis

This is one of the old standbys, and still one of the best. Its long, graceful drooping fronds often attain a length of 6 or 6 feet in a single year.

Fine young plants, each 18c, 28c and $38 \mathrm{c}$, postpaid.

Larger plants, each 97c, $\$ 1.48$ and $\$ 1.94$, by express, not piepaid.

THE OSTRICH PLUME FERN

\section{Nephrolepis Piersonii}

A strong, vigorous grower, resembling the Boston Fern somewhat, but the fronds are much heavier and more feathery, and arch over in a most graceful manner, showing two shades of green and producing a lovely mossy effect. which adds greatly to its beauty.

Fine young plants, each 29c, 38c and 4 \%c, postpaid.

Larger plants, each $96 \mathrm{c}, \$ 1.97$ and $\$ 2.98$, by express, not prepaid.

\section{THE NEW CRESTED FERN}

\section{Whitmanii}

We think this the most popular Fern. Rather dwarf in growth, but graceful, very compact, dense and feathery. Each frond or branch has a double row of perfect litt'e fronds set at right angles to the mid rib, and so thick they seem almost crowded. It is a healthy, vigorous grower, constantly unfolding fresh fronds of light green that contrast exquisitely with the deep green of the older fronds. It is somewhat like Roosevelt, but decidedly more fluffy, more delicate and beautiful

Fine young plants, each $23 \mathrm{c}, 33 \mathrm{c}$ and $43 \mathrm{c}$, postpaid.

Larger plants, each $\$ 1.01, \$ 2.01$ and $\$ 3.01$, by express, not prepaid.

\section{NEWPORT PARLOR FERN}

Resembles the Boston in some respects, but grows more erect, has shorter, narrower fronds and makes three times as many of them. Thrives nicely in parlor or living room, requires very little attention.

Fine young plants, each $23 \mathrm{c}$ to $36 \mathrm{c}$, postpaid.

Larger plants, each $98 \mathrm{c}, \$ 1.98$ and $\$ 2.9 \%$, by express, not prepaid.

Received the Ferns O.K. They sure are nice, healthy looking plants.
Mrs. W. C. Zimmerman.

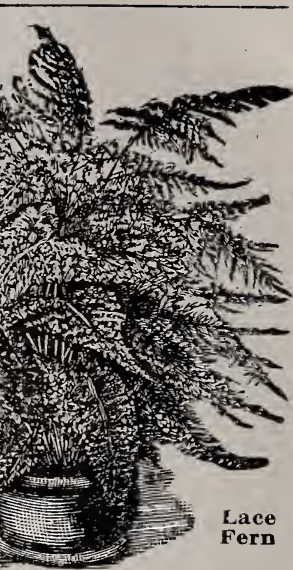

Beautiful

BUCKBEE'S LACE FERN can scarcely be shown by a picture foliage of very delicate texture falls plant has ever been produced. Fine young all conditions. , not prepaid.

BEE'S FEATHER FERN

$y$ the whole year round, profor fine cut flower work, more pared pots it makes a very pretty express, not prepaid.

Dainty and Beautiful

We have grown a large quantity of mall Ferns suitable for Fern dishes. Asorted varieties.

for 52c, postpaid.

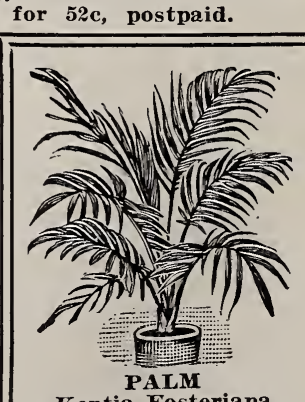

Kentia Fosteriana

Exceedingly popular parlor Palm. Decidedi rugged under all kinds of treatment.

Fine strong plants $41 \mathrm{C}$ each, postpaid. Large specimen plants $\$ 4.99$ to \$7.37 each, by express, not prepaid. 


\section{BUCKBEE'S BEAUTIFUL HARDY SHRUBS}

Buckbee's Beautiful "Full of Life" Shrubs are perfectly hardy, and should be in erery yard. They grow larger and better every year

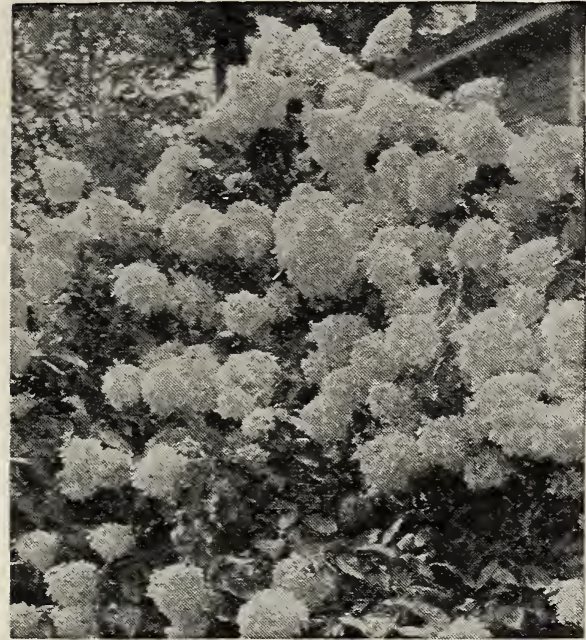

Buckbee's Wonderful Hydrangeas
NEW HYDRANGEA "HILLS OF SNOW"

One of the Most Magnificent Everblooming Hardy Shrubs

Immense snow-white panicles of blooms, literally covering the bush, absolutely hardy, standing 20 degrees below zero without injury. Its long season from early June, through September, renders it doubly valuable as there is no shrub so grandly decorative. Strong plants, postpaid, $29 \mathrm{c}$ each; 3 for 84c; doz. \$2.99. Larger plants, by express, 49c each; 3 for \$1.44; doz. \$4.96. Extra large plants, by express, not prepaid, 74c each; 3 for $\$ 1.99$; doz. $\$ 7.49$.

HYDRANGEA-PANICULATA GRANDIFEORA

Unsurpassed for the lawn. hedge, or cemetery, 5 to 7 feet; hardy in all localities, the flowers are massive, cone-shaped, sometimes 10 inches in length and changing from the original pure white to pink, and coppery red. Fine plants, postpaid, each $24 \mathrm{c}$; doz. \$2.49. Larger plants, by express, not prepaid, each 34c; doz. \$3.49. Extra large plants, by express; not prepaid, each 59c; doz. $\$ 5.97$.

\section{SPIREA}

Bridal Wreath-This lovely old-fashioned shrub is always popular, and justly so, because of its real beauty; bears large spirals of densely crowded pure white flowers, each blossom like a miniature rose the entire length of the branches-and they appear by the millionhence the common title of "Bridal Wreath." A beautiful fioral wreath is made at once by bending and tying the ends of the branch together. Fine plants, 24c each; 3 for $69 \mathrm{e}$, post paid. Anthony Waterer-A perpetual bloomer. Makes a dwarf bush 18 to 24 inches high, covered from Spring until late in the Fall with large heads of lovely crimson flowers, borne in dense clusters and have a peculiar feathery appearance, which is beautiful. Fine plants, 34c each; 3 for 96c, postpaid.

\section{INDIAN CURRANT, OR CORAL BERRY}

A useful shrub for covering banks and dry spots, growing from 3 to 4 feet high. It is spreading in habit and its long slender branches bend gracefully towards the ground. in Autumn it is covered with red currant-like fruit.

Fine Young Plants, 30c each; 3 for 85c, postpaid. Extra Size Plants, 50c each, postpaid.

THE NEW HARDY JAPANESE SNOWBALL

This Japanese variety of the old-fashioned Snowball is one of the grandest and most striking of all hardy shrubs. It forms an erect, compact plant, 6 to 8 feet in height, blooms in June and for a long time the plants are filled with hundreds of big snowy balls that glisten with ethereal whiteness like gems in the sunlight. Strong plants, 35c each; 3 for 950 , postpaid.

\section{SWEET SCENTED SHRUB}

Calycanthus - Spreading growth, bearing throughout the Summer many double. dull brownish purple flowers of exquisite strawberry-like fragrance. Wood and leaves also sweet scented, which causes it to be known as Sweet Scented and Strawberry Shrub Each 34c; 3 for 94c, post paid.

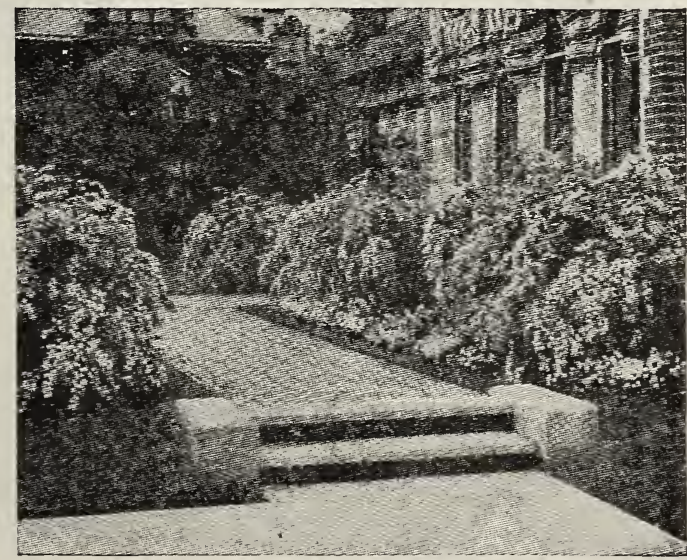

Beautiful Spirea 


\section{BUCKBEE'S CHOICE "FULL OF LIFE"}

\section{HARDY PERENNIAL PLANTS}

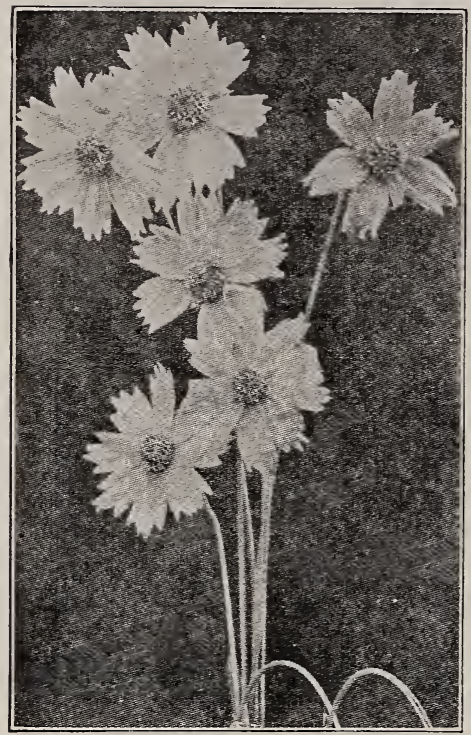

Coreopsis

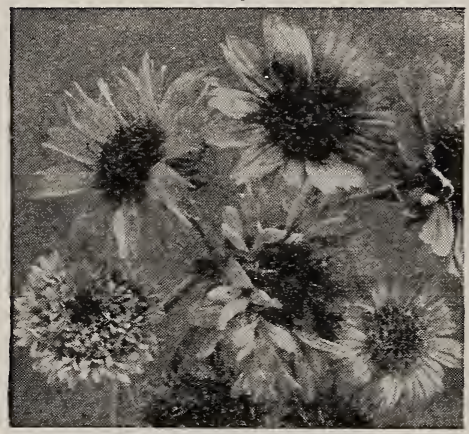

Gaillardia Grandiflora

No class of plants will yield better or more pleasing results for the money invested. They require very little care or attention, are perfectly hardy and yield a rich harvest of bloom. Best results are obtained by fall planting.

BABY'S BREATH (Gypsophila Paniculata) -A beautiful old-fashioned plant possessing a grace not found in any other perennial. Beautiful pure white flowers. Plants grow 2 to 3 feet in height and about the same in diameter. Each 24c; 3 for 69c; doz. \$2.48, postpaid.

BLEEDING HEART-A very popular oldfashioned flower and an ornament to any garden. Delightfully beautiful spring flow ering plants, bearing a profusion of sprays, of rosy-red, heart-shaped flowers. It is perfectly at home in the Perennial border, and is one of the few plants that do well in the shade. Each 45c; 3 for $\$ 1.25$, postpaid.

CANTERBURY BELLS (Campanula Medium) -Beautiful large bell-shaped Howers in blue, rose and white colors. The Medium is the most satisfactory of the Campanulas. It grows 3 feet high on good soil and blooms for a long time, if flowers are cut immediately upon fading and if planted in a half-shady place. Mixed colors. Each $24 \mathrm{c} ; 3$ for $68 \mathrm{c}$; doz. $\$ 2.46$, postpaid.

CoLUMBINE (Aquilegia)-Long-spurred varieties of many rich and varied colors and with broad petals. Two feet high. Columbines are a most important part of the hardy garden and should be grown in quantity. With their airy grace they will serve to lighten up a too stiff and formal planting. Their lasting flowers and long stems are also splendid for cutting. Each $24 \mathrm{c} ; 3$ for $69 \mathrm{c}$; doz. $\$ 2.48$, postpaid.

COREOPSIS (Lanceolata Grandiflora)-One of the most popular hardy plants. The flowers are of a rich golden yellow and invaluable for cutting; continues in bloom the entire Summer and Fall. Each 19c; 3 for 54c; doz. $\$ 1.97$, postpaid.

DELPHINIUM OR LARKSTPUR (Gold Meda) Hybrids)-These flowers are being used with telling effect in our parks and public grounds. They are one of the few hardy blue flowers of any note. By cutting off the flowers as soon as faded, a second and third crop will succeed. Each 25c; 3 for roc; doz. \$2.50, postpaid.

GAILLARDIA GRANDIFLORA-One of the showiest and most effective hardy plants, about 2 feet high, and continuous bloomers from June till cut down by the frost. The flowers are of gorgeous coloring; the center is of dark red-brown, with petals marked with rings of brilliant crimson, orange and vermillion. Excellent for cutting. Each 20c; 3 for $57 \mathrm{c}$; doz. $\$ 1.99$, postpaid.

HARDY GARDEN PINKS-Old favorites bearing their sweet clove-scented flowers in the greatest profusion during the Summer months. Each 23c; 3 for 67c; doz. \$2.44, postpaid.

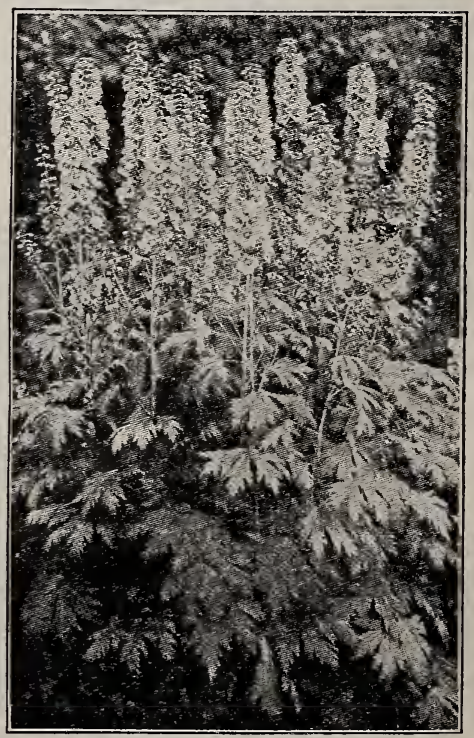

Delphinium or Larkspur 


\section{BUCKBEE'S CHOICE "FULL OF LIFE" HARDY PERENNIAL PLANTS}

Start now to prepare your Perennial Border and add to it every year. You will be surprised how beautiful it will be. Splendid results are obtained by planting in the Fall. Our plants are field grown, strong and healthy.

GOLDEN GLOW (Rudbeckia)-It is a question whether any other hardy perennial has ever met with greater popularity than this It is a strong, robust grower of 5 to 6 feet, and produces masses of double golden yellow castus dahlia-like flowers from July to September. The Golden Glow is indispensable for the hardy perennial border; also makes a most attractive plant when grown alone. Each 20c; 3 for 55c; doz. \$2.00, postpaid.

HOLLYHOCK (Buckbee's New Hybrids)Few hardy plants combine as many good qualities as the Hollyhock. The flowers form perfect rosettes of the most lovely shades of color. It requires a rich, deep soil, well drained, and will repay in quantity and elegance of bloom any extra care. A slight protection during the Winter will be beneficial. Each 24c; 3 for 69c; doz. \$2.48, postpaid.

LADY IN WHITE (The Famous Cemetery Plant)-One of the very best white flowered plants for the border. The flowers are borne in the greatest profusion the entire Summer on strong, erect stems, pure white in color. Each 24c; 3 for 68c; doz. \$2.46, postpaid.

PAINTED DAISIES (Pyrethrum)-This grand old-fashioned hardy perennial is easy to grow in any good garden soil where there is good drainage and full exposure to the sun. Their main season of blooming is in June. The fine, fernlike foliage of the plants is attractive at all times. "The plants which we offer embrace all the colors from deep red through the various shades of rose to pure white. These can be supplied in mixed colors only. Each 25c; 3 for 70c; doz. \$2.50, postpaid.
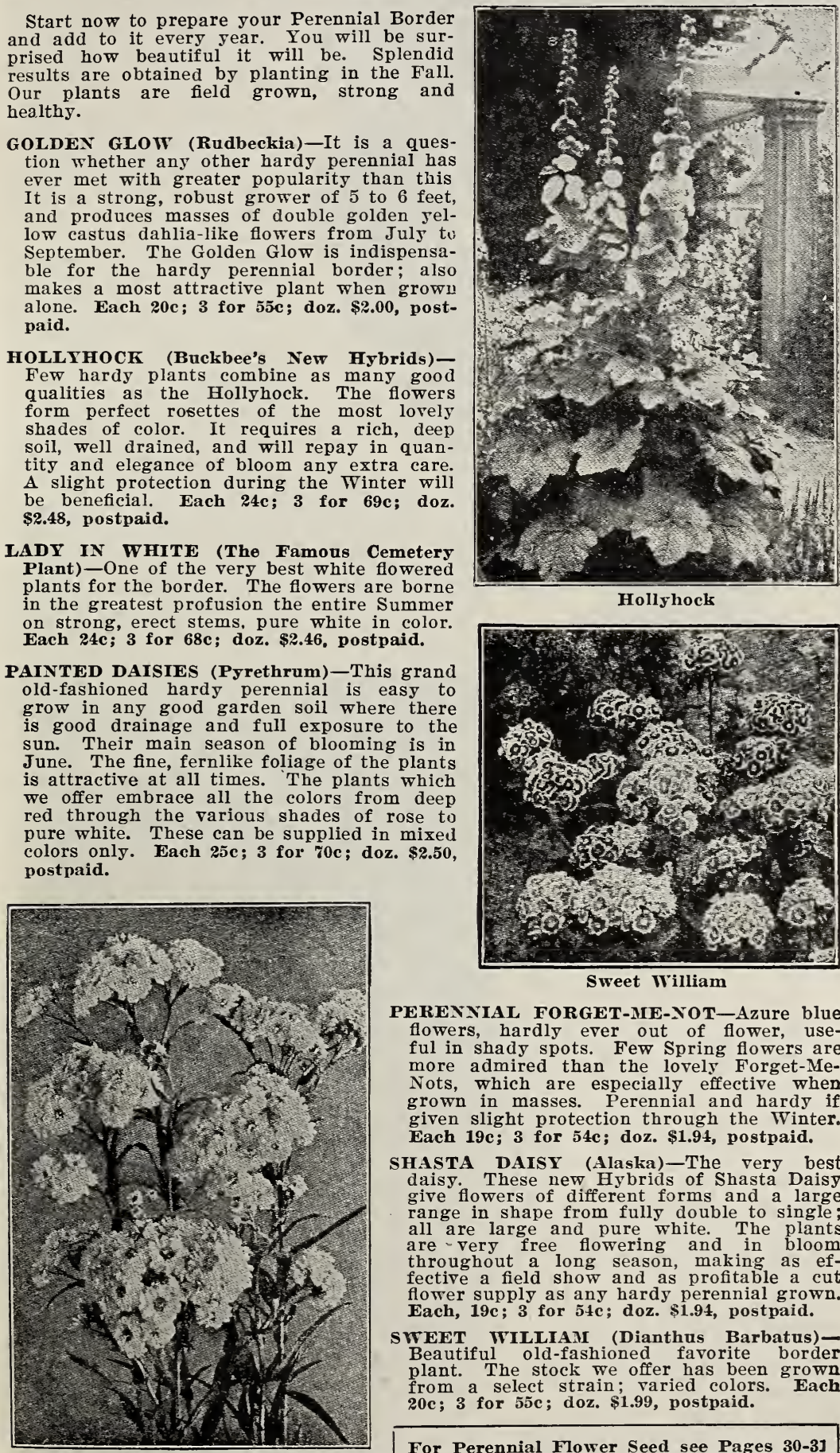

Hollyhock

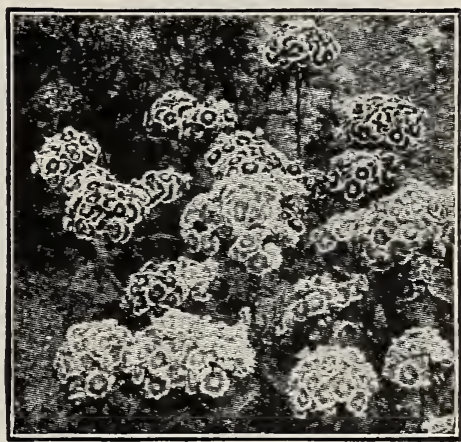

Sweet William

PERENYIAL FORGET-ME-NOT-Azure blue flowers, hardly ever out of flower, useful in shady spots. Few Spring flowers are more admired than the lovely Forget-MeNots, which are especially effective when grown in masses. Perennial and hardy if given slight protection through the Winter. Each 19c; 3 for 54c; doz. $\$ 1.94$, postpaid.

SHASTA DAISY (Alaska)-The very best daisy. These new Hybrids of Shasta Daisy give flowers of different forms and a large range in shape from fully double to single: all are large and pure white. The plants are-very free flowering and in bloom throughout a long season, making as effective a field show and as profitable a cut flower supply as any hardy perennial grown. Each, 19c; 3 for 54c; doz. $\$ 1.94$, postpaid.

SWEET WILLIAM (Dianthus Barbatus)Beautiful old-fashioned favorite border plant. The stock we offer has been grown from a select strain; varied colors. Each 20c; 3 for 55c; doz. \$1.99, postpaid. 


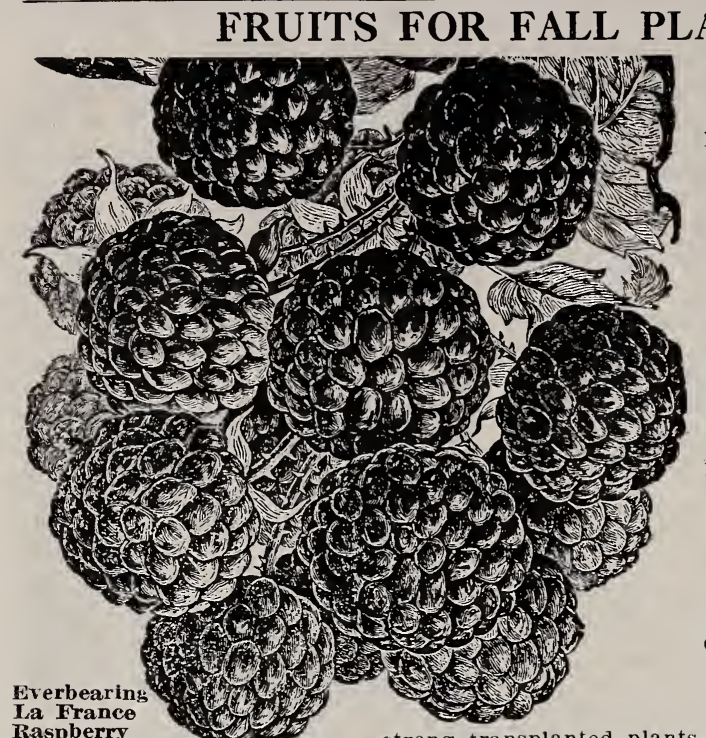

\section{LANTING \\ RASPBERRIES THE BEST RED VARIETIES}

Ia France

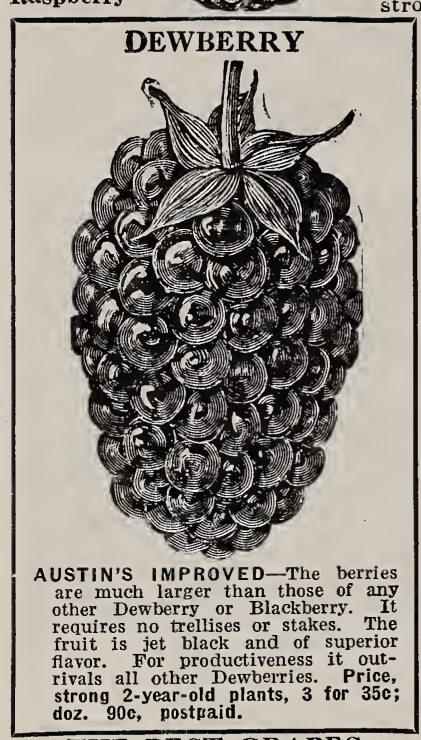

\section{THE BEST GRAPES}

CAMPBELL'S EARLY - Large, glossy black, sweet and juicy. Strong plants, each 25c; 3 for r0c; doz. $\$ 2.50$, postpaid.

WHITE DIAMOND-Best white, healthy and perfectly hardy. Strong plants, each 25c; 3 for Strong plants,

MOORE'S EARLY -Early, large, round and with a black-blue bloom. Strong plants, each $25 \mathrm{c}$; 3 for $70 \mathrm{c} ;$ doz. $\$ 2.50$, postpaid. CONCORD-The well-known standard black-blue variety. Strong plants, each, 20c; 3 for $55 \mathrm{c}$; plants, each, 20c;

WORDEN -A large black grape of the Concord type, but 5 to 10 days earlier. Strong plants, each 25c; 3 for 70c; doz. \$2.50, postpaid.

Special Offer The set of 5 by mail, postpaid, 0 ly one of each variety, Only $\$ 1.08$
NEW EVERBEARING LA FRANCE. Bears Fruit for Four Months-It is the first Red Raspberry to give ripe fruit, and continues to produce berries without intermission until October. The berries are surpassing in qualityrich, sugary, with full Raspberry flavor. They are of exceedingly meaty, firm texture, and keep in good condition for a very long time after being gathered. Fine, strong, transplanted plants, $21 \mathrm{c}$ each ; 3 for $59 \mathrm{c}$; doz., $\$ 1.74$, postpaid.

NEW EMPIRE-The hardiest Raspberry; a strong, vigorous grower, fruit bright red, very sweet and juicy. Earlier and with larger berries than most others. Fine strong transplanted plants. Price, 19c each; 3 for $49 \mathrm{c}$; doz. $\$ 1.49$, postpaid.

COLUMBIAN-Reddish, purple or dark blue color, rich flavor, very large size. An excellent shipper, and the best for canning and drying. Late. Fine THEd plants, 3 for 35c; doz. 90c, postpaid. BUCKBEE'S BLACK KING-The best and largest Black Raspberry. Fruit is of large size, wonderful flavor, splendid appearance and very sweet. Fine, strong, transplanted plants, 19c; 3 for 49c; doz. s149. postpaid.

CU1BERLAND-A large Black Raspberry, averaging $7 / 8$ inch in diameter. Good and firm and one of the hardiest varieties grown. A strong, vigorous grower and wonderfully productive. Mid-season. Fine, strong, transplanted plants, 3 for 35c; doz. 90c: postpaid.

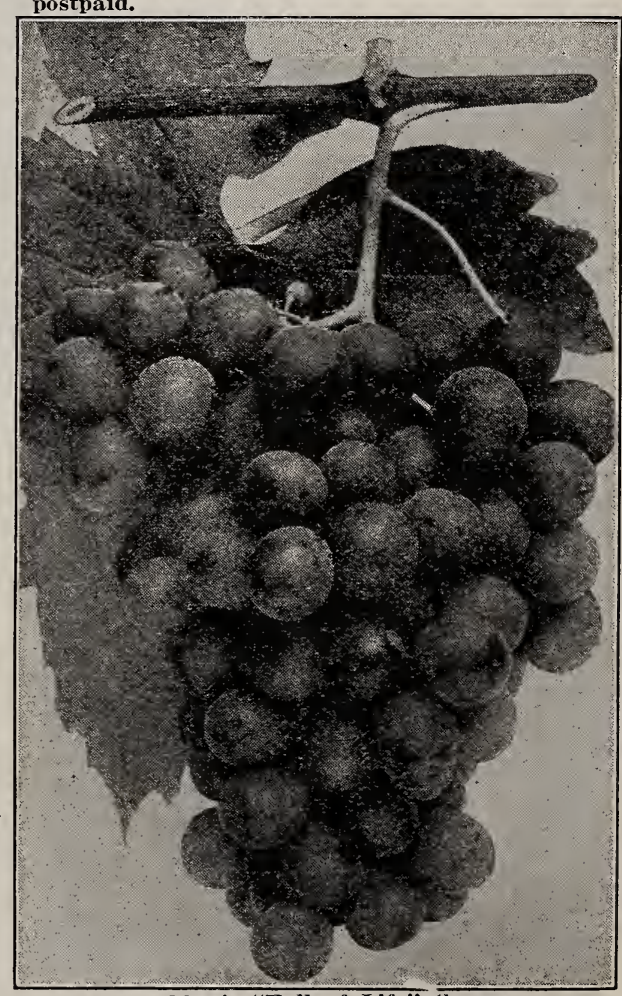

Buckbee's "Full of Life" Grapes 


\section{Buckbee's "Full of Life" Strawberry Plants}

Strawberry Plant Orders will be shipped direct from our Strawberry Farms and cannot be shipped with other goods. Send jour orders in early-please.

Our plants are suited to all soils and climates. 100 Plants will supply an ordinary family with fresh fruit all season.

Set out Buckbee's "Full of Life" Strawberry Plants.

Start Right! Get the Best. Order early.

\section{NOTICE}

All rarieties marked $(\mathrm{S})$ are Staminate Perfect Flowering and Bi-Sexual rarieties.

All rarieties marked $(P)$ are Pistillate and destitute of Stamens.

Therefore when planting rarieties marked $(P)$ it will be necessary to have erery third row a Perfect Flowering or (S) rariety to properly fertilize the bed; much finer fruit will be obtained by so doing.

We hare marked after each rariets. whether they are early, medium early or late in bearing fruit.

WE WARRANT all shipments of Strawberry Plants to reach purchaser's hands in good growing condition and when so accepted, no orders will be duplicated or replaced for any cause.

Select List-

American Beautr, $\mathrm{S}$ (Medium) .............

Americus (Everbearing) $\ldots \ldots \ldots \ldots \ldots \ldots \ldots .10$

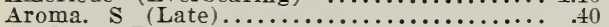

Cardinal, P (Late)............................

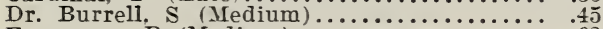

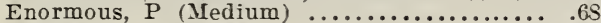

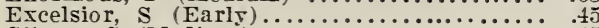

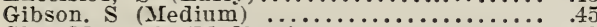

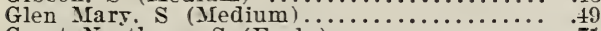

Great Northern, S (Early)...............71

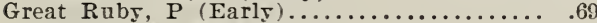

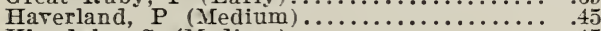

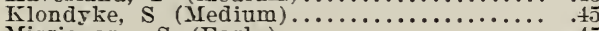

Missionar $\mathrm{S}$ (Early) ...................

Premier. $s$ (Earls) ....................... 64

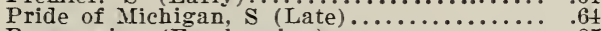

Progressice (Everbearing) .................. .5.

Senator Dunlap. S (Medium)..............40

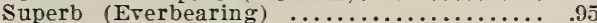

Warfield. P (Medium) ..........................

Wr. Beit, $\mathrm{S}$ (Medium) .......................
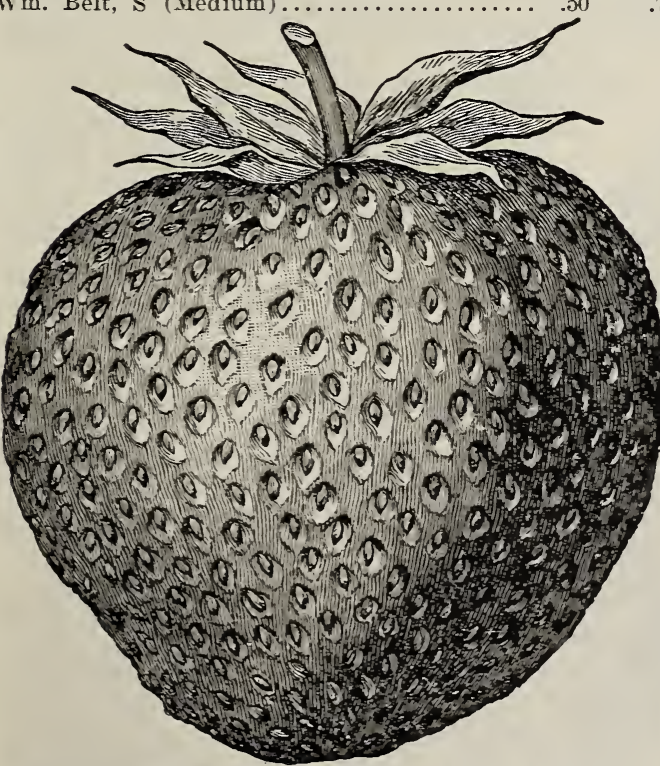

American Beauty-The World's Finest Strawberry

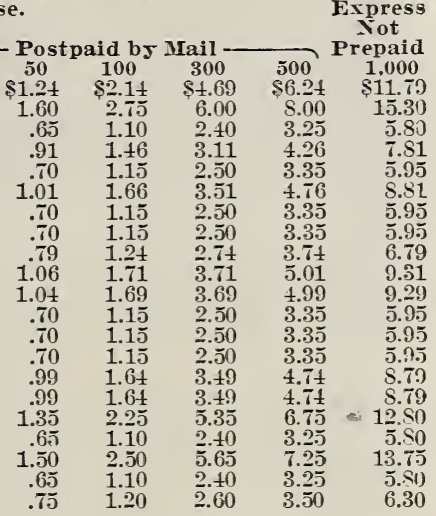

\section{Peerless
Collection $\$ 1.07$}

STRAWBERRT PLANTS

Dr. Burrell, 25 selected

By
Mail

Plants. Value........450

Great Northern, $25 \mathrm{Se}$ -

lected Plants. Value...r1c

Warfield, 25 Selected

Plants. Value........40c

In all, is plants, value \$1.56, for \$1.0\%, postpaid.

\section{Matchless $\$ 1.97$
Collection $\$ 1.97$ STRAWBERRT PLANTS

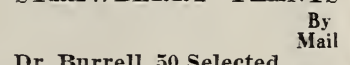

Plants. Value.......\$0.70

Great Northern, 50 Se-

lected Plants. Talue 1.06

Warfield, 50 selected

Plants. Value........ .65

In all, 150 plants, ralue \$2.41, for \$1.9\%, postpaid. 


\section{BUCKBEE'S 'FULL OF LIFE" BEAUTIFUL PANSIES FOR AUTUMN PLANTING}

To have the earliest flowers, Pansy seeds should be sown in the fall, any time from August to November. They are quite hardy and all the Winter protection they need is a little brush or straw to keep the snow from pressing too heavily upon them. If you want Pansy blooms early in the Spring, try this plan.

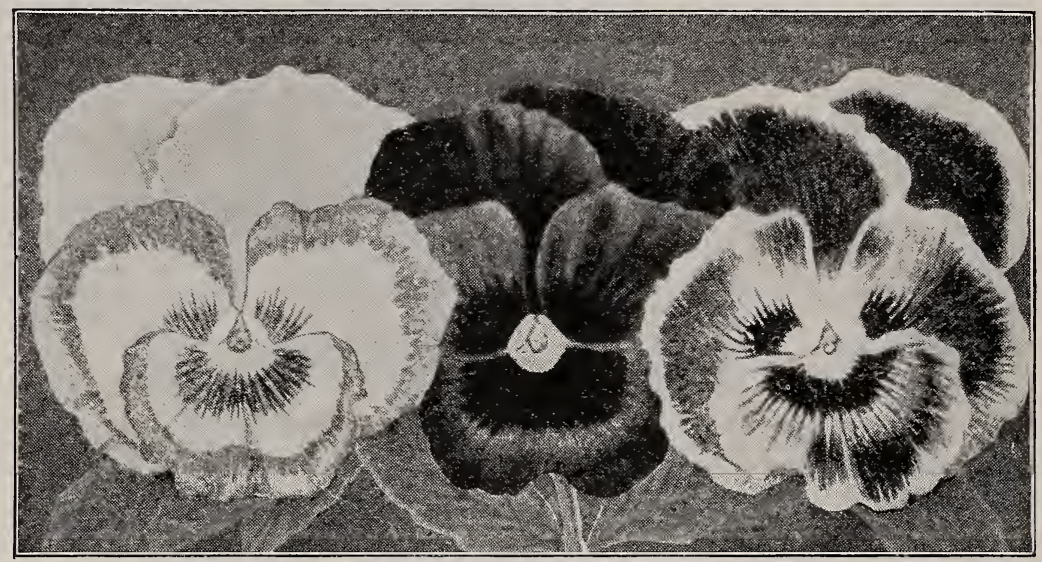

Steele's New Mastodon Pansy

STEELE'S NEW MASTODON PANSIES

The largest Pansy ever grown. Nothing like it ever seen before. Elowers come in every known color, and show shades never seen in any other strain. Blooms very early and continuously. The enormous flowers are of thick velvety texture, perfect form and are borne on long, strong stems well above the foliage. If you want the largest Pansies ever grown plant Steele's Mastadon. Packet of about 50 seeds 15c.

\section{BUCKBEE'S MAMMOTH JUBILEE MIXTURE}

A wonderful mixture of beautiful Pansies. All are of immense size. Many are deeply fluted and frilled, while others have variations and markings that cannot be described. Our new stock seed is now ready and our Jubilee Mixture this Fall is even better than before. Packet 12c; $1 / 8$ oz. 95c.

\section{BUCKBEE'S GIANT FLOWERING MIXED}

In this magnificent mixture of giant flowering Pansies the colorings are wonder-

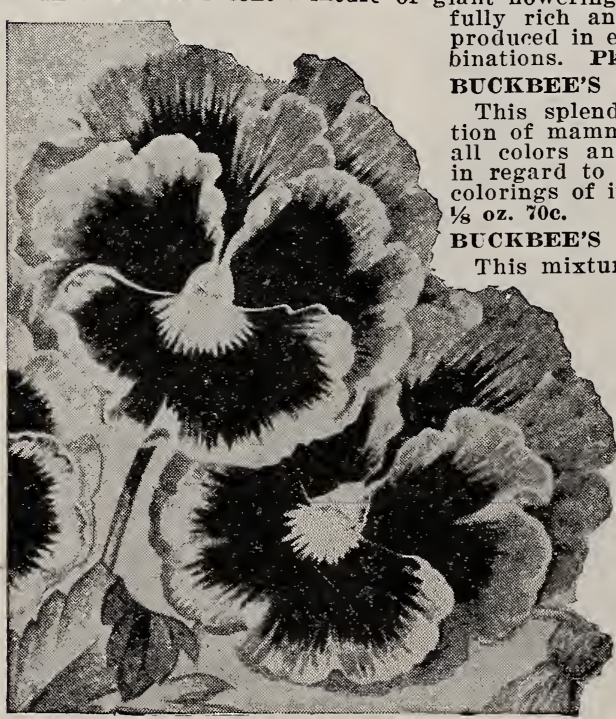

Buckbee Mammoth Jubilee Pansy fully rich and varied; every shade and tint is produred in endless variations and striking comBUCKBEE'S MAMMOTH SUNRISE MIXTURE This splendid mixture is a blended combinaThammoth flowering Pansies. It contains all colors and will prove a delightful surprise in regard to the great size and rich and varied colorings of its flowers. Very popular. Pkt. 8c; oz. \%0c.

WORLD'S FAIR PRIZE MIXED was awarded Grand Prize Medal at the World's Fair. It is an exceedingly fine mixture, producing flowers of rare beauty in both colorings and markings. Pkt. 7e; $1 / 8$ oz. 40c.

BUCKBEE'S SWEET SCENTED MIXTURE

The Perfume of the Violet. The Beauty of the Pansy

This new class is the result of crossing the Pansy (viola tri-color) with the Sweet Violet (viola cornuta) the resulting bybrids, in addition to retaining the delightful Violet perfume, produce the most beautiful Pansy-like blossoms, 2 to $21 / 2$ inches across, of great substance and of an endless variety of colors. Mrixed. Pkt. $8 \mathrm{c}$; 1/8 oz. 400 


\section{BUCKBEE'S "FULL OF LIFE" FLOWER SEEDS}

\section{FOR FALL P.LANTING}

\section{CONDENSED LIST OF STANDARD VARIETIES}

By sowing hardy rarieties of flowers from August to October a brilliant display of flowers can be secured at a small cost quite early in Spring at a time when usually the garden is comparatively bare, and these plants from Autumn sown seeds generally become larger and more robust and flower more profusel 5 than if sown in Spring. Perennial flowers especially should be sown in Fall as most of them will not bloom the first Fear it sown in Spring, but if sown earls enough. not later than October ther can make good plants before frost, and will bloom freely the following year.

The varieties marked Per. are perennials.

(See general catalog for description of rarieties.) Prt.

Alyssum, Sweet, white, sweet scented..........6. $6 \mathrm{c}$ Alyssum, Little Gem .................... 8c Antirrhinum (Snapdragon), Giant Mixed..........10c Antirrhinum. Dware, mixed Gorts

California Poppy, Buckbee's Fancy yixed......... 8c

Canterbury Bells, single mixed. Per.............. 6c

Canterbury Bells, double, mixed. Per.............. 8c

Candytuft, all colors, mixed................ 6c

Centaurea Cyanus, double mixed colors (Bachelor's

Centaurea Cyanus, double mixed colors (Bachelor's $7 \mathrm{c}$ Chrysanthemuni, French Marguerites................ 7c Coreopsis, Grandiflora, golden sellow. Per..... Tc Daisy, Double, Mammoth Mixed. Per........... ic Daisy Shasta. Per............................ Dianthus, China or India, mixed...................6 60 Dianthus, Fringed and Ruffled...................... 7 Dianthus, Plumaris, Hardy Garden Pinks, mixed

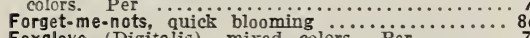
Foxglove (Digitalis), mixed colors. Per........... 7c Gaillardia. Mixed. Per..................... .c Hollyhocks, mixed colors, prize double. Per.......

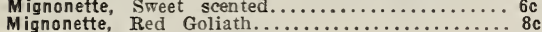

Mignonette, Rockford Mixed.

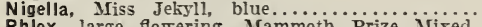
Phlox, large flowering, Mammoth Prize Mixed.... 8c

Phlox, Perennial or Hardy. Per...........

Pcabiosa Caucasia larander-blue Per...

Scabiosa, Caucasia, lavender-bl.

Stokesia, cyanea, blue. Per............

Sweet William, double mixed. Per

Violas or Violets, finest mixed. Per.

TARIETIES REQCIRING INDOOR CULTURE

Carnation, Buckbee's Everblooming, mixed........10c Cineraria, Large Flowered Mixture.............. 10c Coleus, finest mixed hybrids .................. Cyclamen, Buckbee's Large Flowered Mixed........ I5c Fuchsia, single and double, mixed.............. Geranium, California Giants .................. 10c Gloxinia, Hybrida Grandifiora, mixed colors......10

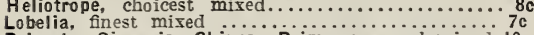
Primula, Sinensis, Chinese Primrose, superb mixed. 10c Primula, Sinensis, double flowering, finest mixed..18c Primula, Sinensis, double flowering, finest mixed..18c

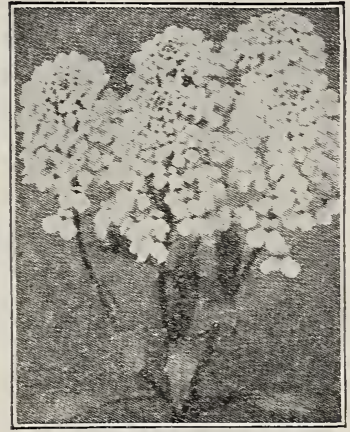

1, oz. $10 \mathrm{c}$ 1 oz. $25 \mathrm{c}$

$1 / 8$ oz. $15 \mathrm{c}$

18 oz. $\quad 15 \mathrm{c}$

$1 / 4$ oz. $20 \mathrm{c}$

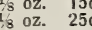

$1 / 2$ oz. $\quad 15 c$

$18 \mathrm{oz} . \quad 25 \mathrm{c}$

1' oz. $20 \mathrm{c}$

$1 / 8$ oz. $\quad 15 \mathrm{c}$

$1+$ oz. $25 \mathrm{c}$

$1 \mathrm{~s}$ oz. $40 \mathrm{c}$

18 oz. $30 \mathrm{c}$

is oz. $40 \mathrm{c}$

$1 / \mathrm{oz} . \quad 15 \mathrm{c}$

1s $0 \mathrm{z}, 20 \mathrm{c}$

${ }^{1} \mathrm{~s}$ oz. $20 \mathrm{c}$

$1 / 8$ oz. $35 \mathrm{c}$

is oz. $20 \mathrm{c}$

$18 \mathrm{oz}$. $25 \mathrm{c}$

oz. $20 \mathrm{c}$

$1 / 8 \mathrm{oz} . \quad 25 \mathrm{c}$

$1 / 2$ oz. 20c

4 oz. 200

is oz. $30 \mathrm{c}$

8 oz. $40 \mathrm{c}$

18 oz. $25 \mathrm{c}$

8 oz. $40 \mathrm{c}$

is oz. $25 \mathrm{c}$

1 s oz. 25c

$1, \mathrm{oz}$. $40 \mathrm{c}$

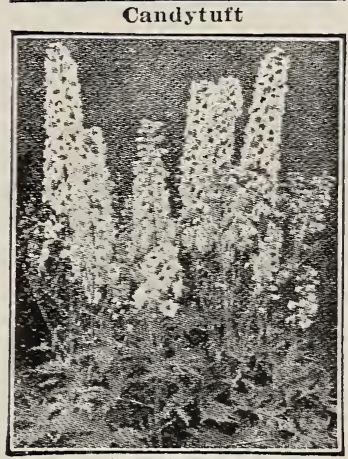

Delphinium

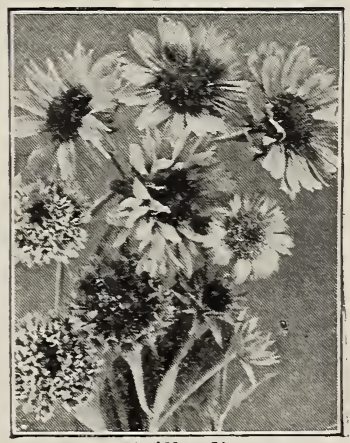

Gaillardia

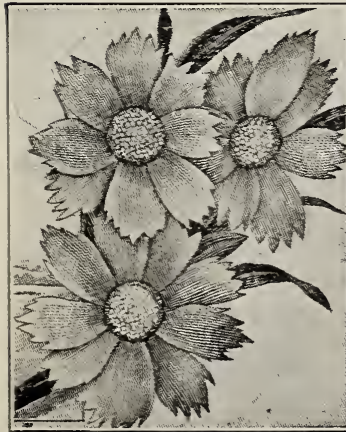

Coreopsis

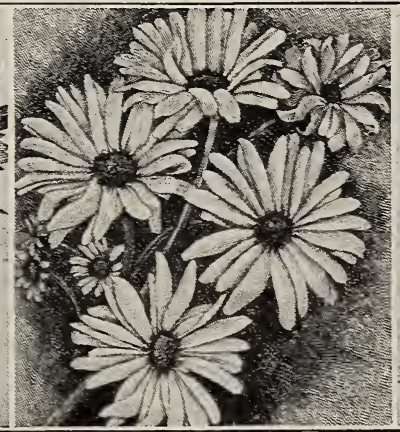

Shasta Daisy

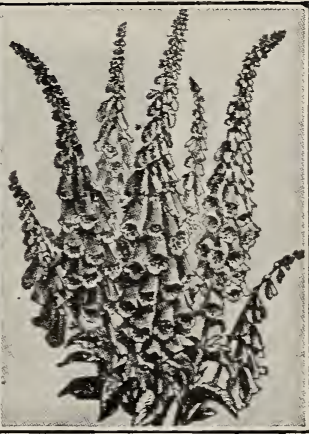

Fox Glove 


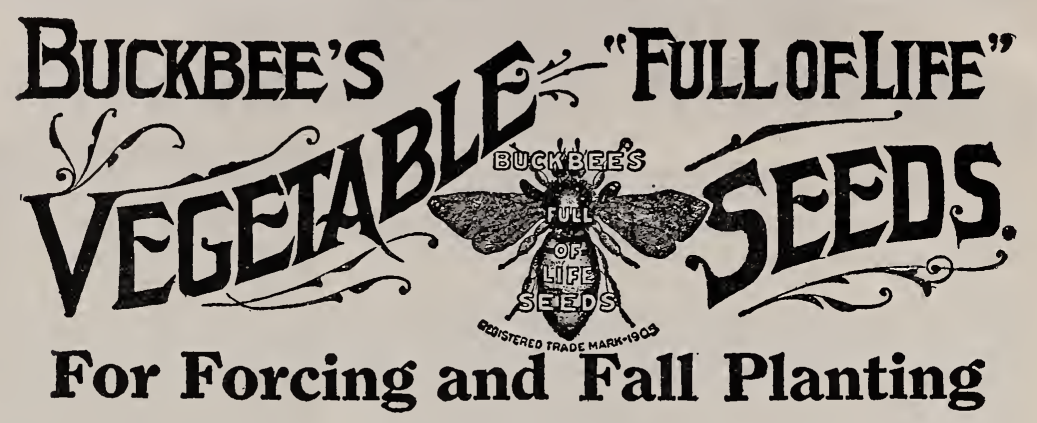

\section{Condensed List of Standard Varieties}

For complete list of Garden Seeds and Bulk Prices see our big illustrated annual catalog, copy of which was sent you last spring.

BEANS

60 li/2 $\begin{aligned} & \text { lbs. will plant a } 100 \text {-foot row } \\ & \text { lbs. will plant an acre }\end{aligned}$

(Write for Prices on Larger Lots)

Postpaid

Buckbeo's Improved Early Valen Pkt. $1 / 2 \mathrm{lb}$. Lb.

tine $\ldots . . \ldots \ldots \ldots \ldots \ldots \ldots$. 10 $22 \mathrm{c} \quad 40 \mathrm{c}$

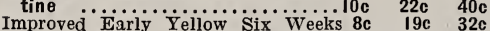

Improved Earf erra or Wren's Weeks 8c 19c $32 \mathrm{c}$

Dwarf Cranberry or Wren's Egg..10 $22 \mathrm{c}$ 40c

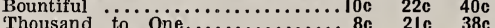

Thousand to One............. 8c 21c 38c

Bew Extra Early $\begin{gathered}\text { Refugee........ 8c } \\ \text { Buckbee's Early Wonder.........10 }\end{gathered}$

Buckbee's Early Wonder..........10c 25c 45 c

$\begin{array}{llll}\text { New Stringless Green Pod ... W...10c } & 24 \mathrm{c} & 44 \mathrm{c} \\ \text { Buckbee's Rust Proof Golden wax. } 10 \mathrm{c} & 22 \mathrm{c} & 40 \mathrm{c}\end{array}$

New Prolific German or Imp.

Black Wax .............. 8c 2lc 38c

Currie's Rust-Proof Black Wax.. 8c 21c 38c

New Davis White Wax.........10e 23c 42c

Wardwell's Improved Kidney Wax. 10c 25c 45c

Buckbee's Wonder Wax..........10c 25c 45c

$\begin{array}{llll}\text { Improved Golden Wax..........8 } & \text { 2lc } & 38 \mathrm{c} \\ \text { New Yosemite Mammoth Wax...10c } & 25 \mathrm{c} & 45 \mathrm{c}\end{array}$

Jones' ${ }^{\circ}$ Stringless White Wax....10c 25c 45c

New Brittle Wax...............10c 280 48c

\section{BEE' $\mathbf{T}$}

I oz. will plant a 50-foot row 7 lbs. wili plant an acre

Pkt. 0 z. $1 / 4 \mathrm{lb}$.

Buckbee's Long Blood........... 5c Imp. Extra Early Eclipse........ 5c Buckbee's Sunset (the best).......10 c Imp. Early Blood Turnip......... 5c Crimson Globe $\ldots \ldots \ldots \ldots \ldots \ldots \ldots$ 7c Crosby's Early Egyptian.......... 7c Detroit Dark Red Turnip....... 8c Buckbee's Egyptian Turnip...... 8 The Bismarck $\ldots \ldots \ldots . . . . .60$ Buck, Earliest of All....... Buckbee's Earitiest of All.......... Swiss Chard, Lucullus...........

\section{CABBAGE}

I oz. seed should produce 2500 plants Sow $1 / 2 \mathrm{lb}$. seed to transplant for an acre

Extra Early Winningstadt........7c 25c 65c Buckbee's Great Dane.............. Buckbee's New Racehorse.........10c 35c 1.20 True Early Jersey Wakefield..... 8c 25c 80 Charleston or Large Wakefield..... 7c 25c 75c Buckbee's Extra Early Large New Queen, New................. Buckbee's New Xmas King.......10 40 40 1.25 Allhead Early .............. 8c 25c 65c

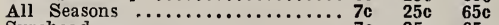
Surehead $\ldots \ldots \ldots \ldots \ldots \ldots \ldots \ldots 7$ 7c 25c 65c Glory of Enkhuizen............ $3 c$ 25c 75c Copenhagen Market $\ldots \ldots \ldots \ldots \ldots$ 8c $30 \mathrm{c} \quad 1.00$ Buckbee's Mam Late Fiat Dutch 8c 280 Mam Bridgeport. Drumhead..... 80 250 800 Mam. Bridgeport Drumhead...... 8c 25c 80c New Round Head 0 i.jin......... 8c 250 80 New hound Head 'Danish.......... 3c 30e 90e Now Red Polish Loaf Savoy.......

\section{CARROT}

I oz. will plant a 200-foot row 4 lbs. will plant an acre

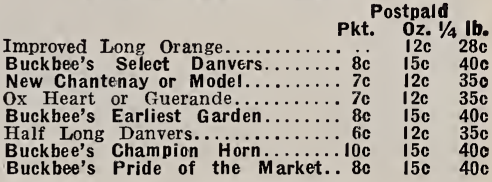

CAULIFLOWER

1 oz. seed should produce 2000 plants Buckbee's Extra Early Chief.......15c $3.00 \quad 10.00$ True Early Snowball.............10 $2.25 \quad 7.50$ Buckbee's Early Favorite........ 8c $1.00 \quad 3.50$ LeNormand's Short Stem....... 7c 80c 2.65 Extra Early Paris.............. 70 75c 2.50

\section{CELERY}

I oz. seed should produce 5000 plants Sow $1 / 4$ lb. seed to transplant for an acre

Buckbee's Easy Blanching........10c 50c 1.75 Buckbee's All Heart..............10 $30 \mathrm{c} \quad 1.05$

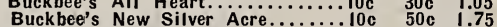
Buckbee's Golden Heart...........7c 20c $65 \mathrm{c}$ Golden Yellow Self-Blanching..... 8c 40 c 1.45 Gow Giant Pascal.............. White Plume (finest strain).......7c 7c 25c 80c Celeriac, Large Smooth Prague...6 6c 25c ... Celeriac, Large Smooth Prague...6 6c ${ }_{\text {Celeriac, New }}^{25 c} \ldots .$.

\section{CUCUMBER}

I oz. will plant 50 hills

3 lbs. in hills will plant an acre

Early Cluster $\ldots \ldots \ldots \ldots \ldots \ldots$ 7c 12c 35c

Buckbee's Rockford Pickle..........10 is $40 \mathrm{c}$

Buckbee's Monarch White Spine..10c I5c 450

New Extra Early Long Green.....10 10 15c 45c

Davis Perfect ................. $15 \mathrm{c}$ (50

Early Prolific "Short Green.........6. 12c 35 ce

New Everbearing $\ldots \ldots \ldots \ldots \ldots \ldots .8 \times$ 8c $12 \mathrm{c}$ 35c

Snow's Pickling $\ldots \ldots \ldots \ldots \ldots \ldots$ 7c 12c 35c

\section{COLLARDS}

I oz. seed should produce 3000 plants

Georgia $\ldots \ldots \ldots \ldots \ldots \ldots \ldots \ldots .5 \mathrm{c} \quad 10 \mathrm{c} \quad 28 \mathrm{c}$

CORN SALAD

I oz. will plant a row 50 feet long Or Fetticus $\ldots \ldots \ldots \ldots \ldots \ldots \ldots, 60 \quad 12 \mathrm{c} \quad 35 \mathrm{c}$

\section{EGG PLAN'T}

I oz. seed should produce 1000 plants Buckbee's New Early Large Pur-

ple $\ldots \ldots \ldots \ldots$...................10 45 $\quad 1.50$ Buckbee's New White........... 8c 40 1.35 Improved New York Purple...... 7c 38c 1.25 Extra Early Long Purple.......... 7c 35 35c $\ldots$ 


\section{ENDIVE}

I oz. will plant a 100 -foot row Postpaid
Pkt. $02.1 / 4 \mathrm{lb}$ Giant Fringed .............. $8 \mathrm{c}$ 15c $40 \mathrm{c}$

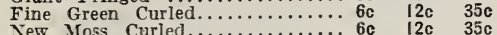
Broad Leaved Batavian (Escarolle) 7c $12 \mathrm{c} \quad 35 \mathrm{c}$

KALE OR BORECOLE

I oz. will plant a 150 -foot row Dwarf Excelsior Green Moss

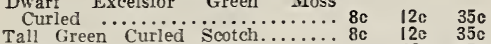

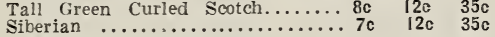

\section{KOHL RABI}

I oz. will plant a 200-foot row Improved Early Imperial Purple.. 7c 25c 65c King of Earliest White.......... 8c 25c 70c

\section{LEEK}

I oz. will plant a 100-foot row

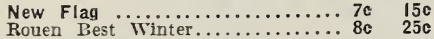
$65 c$

\section{LETTCCE}

I oz. will plant a 100-foot row 4 ibs. will plant an acre

New Iceberg .............. 8c $15 c$ Imp. Black Seeded Simpson....... 7c Buckbee's Earliest Foreing........ Simpson's Early Curled.........6 6c Improved Hanson ............ 8c $^{8}$ Dwarf White Heart or Celery.... 8c Paris White Cos......... H.....7c Buckbee's Mammoth All Head.... 10 'Tomhannock .................. 8c Buckbee's lce Drumhead Early Prizehead

Buckbee's Mammoth Big Boston... 8c Grand Rapids (Private Stock).... 8c All Seasons ................ 8c Extra Early iay King..............

\section{MUSTARD}

I oz. will plant a 150 -foot row Yew Chinese ............... Creole Southern Curled.......... 7c

\section{ONION}

I oz. will plant a 100 -foot row 6 Ibs. will plant an acre Round or Yellow Danvers........ 7c 12 c Buckbee's Pedigree Red Wethers. field $\ldots \ldots \ldots \ldots \ldots \ldots \ldots \ldots .8 \mathrm{c} \quad 15 \mathrm{c}$ Southport Yellow Globe......... 8c $16 \mathrm{c}$ New Genuine Prizetaker..........10 18c Buckbee's Mam. Silver King......10 $20 \mathrm{c}$ Buckbee's New Denia............. Buckbee's New Golden Globs..... 8c $8 \mathrm{c}$ Australian Brown $\ldots$ Portuga......... 7c Southport Red Globe (Select)..... 8c Southport Selected White Globe...10c Buckbee's Yellow Globe Danvers... 7c Extra Early White Queen........7c Buckbee's White Pickling......... White Berm Welsh............... Red Bermuda $\ldots \ldots \ldots \ldots \ldots \ldots \ldots \ldots \ldots \ldots$ loc Crystal White Wax. Crew Sweet Spanish................

\section{PARSLEY}

I oz. will plant a 150-foot row Buckbee's Beauty $\ldots \ldots \ldots \ldots \ldots \ldots \ldots 100 \quad 15 \mathrm{c}$
New Moss Curled..............

\section{RADISH}

I oz. will plant a 100-foot row 12 lbs. will plant an acre Scarlet Turnip, White Tip (Select) 5c 10c 25c Buck Rosy Gem.............. $6 \mathrm{c} \quad 12 \mathrm{c} \quad 35 \mathrm{c}$
RADISH-Cont.

Postpaid

Pkt. 0z. $1 / 4 \mathrm{Ib}$.

Buckbee's Rapid Forcing........10 c 15c 400

Buckbee's Rockford Market.......7c 12c $35 \mathrm{c}$

Earliest Scarlet Turnip......... 5

Buckbee's Rockford Beauty.........10 $15 \mathrm{c}$

Buckbee's New Early Red King... 8c I2c $35 \mathrm{c}$

Crimson Giant Globe.......... 8 8 c 12c $35 \mathrm{c}$

Earliest Srench Breakfast......... 7c 12c 30c

Buckbee's I mproved Chartiers..... 5 $\mathrm{c}$ 10

New White Lady Finger......... 6c 12c 30c

Cardinal or Long Brightest Scarlet $7 c$ I2c $30 \mathrm{c}$

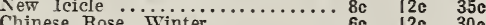

Golden Summer Turnip...........6.

White strasburg ............. 6

California Mammoth White........ 6e 12c 30 c

Long Black Spanish, Winter....... 6e 12c $30 \mathrm{c}$

Buckbee's Mammoth Celestial,

Winter ................... $8 \mathrm{c}$ 15e 40 e

Earliest Radishes Mixed........6. 6c 12c $30 \mathrm{e}$

Summer Radishes Mixed.........6. $6 c \quad 12 c$
Winter Radishes Mixed..........6.

\section{SPINACH}

I oz. will plant a 100-foot row 12 Ibs. will plant an acre

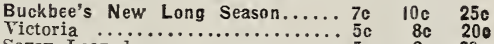

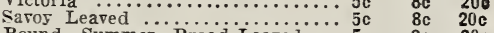
Round Summer Broad-Leaved 5c 8c 200 Princess Juliana $\ldots \ldots \ldots \ldots \ldots \ldots \ldots .5 \%$
Prickly, or Winter.... Monstrous Virotlay $\ldots \ldots \ldots \ldots \ldots .5 \mathrm{~s}$. 8c $20 \mathrm{e}$

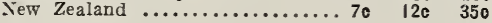

\section{TOMATOES}

I oz. seed should produce 1500 plants Sow $1 / 4$ Ib. seed to transplant for an acre New Stone (Special Stock)...... 7e 25c Buckbee's New Beefsteak .......... Buckbee's Earliest Market.......... Buckbee's New Early Banuiet..... Liringston's Beauty ........... $8 \mathrm{c}$ 30 $\quad 1.00$ Abraham Lincoln ................. Ponderosa or No. $400 \ldots \ldots \ldots \ldots \ldots .10 \mathrm{c}$. $50 . \mathrm{c} \quad \mathbf{1 . 7 0}$ Buckbee's New Tree................ New John Baer................ 8c $35 \mathrm{c} \quad 1.20$ Buckbee's Prosperity ......... 8c 45c 1.50 New Earliana $\ldots \ldots \ldots \ldots \ldots \ldots \ldots$. $8 \mathrm{c}$ 30 $90 \ldots$ Chalk's Early jewel............ 8c 30 $90 \mathrm{c}$ Livingston's Globe $\ldots \ldots \ldots \ldots \ldots$ l0 c $40 \mathrm{c} \quad 1.45$ Buckbee's New Masterpiece.......15c 75c 2.25

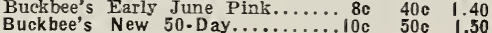
Bonny Best ................... 8 30 c $\quad 1.05$

\section{TURNIPS}

I oz. will plant a 100-foot row 3 lbs. will plant an acre

Buckbee's Purple Top Strap Lear (Special Stock) .............7c New White Egg................ 7c New Golden Globe............. 8c Imp. Early White Flat Dutch.... 5c Early Six Weeks, or Snowball...8 8c Buckbee's Extra Early Cameo Buckbee's New Purple Top Whito 70 Extra Eariy Purple Top Mila.... 8c Extra Eariy Purple Top M.....

$\begin{array}{ll}10 c & 25 c \\ 10 c & 28 c \\ 12 c & 28 c \\ 10 c & 25 c \\ 12 c & 28 c \\ 12 c & 35 c \\ 12 c & 30 c \\ 12 c & 35 c \\ 10 c & 25 c \\ 10 c & 25 c\end{array}$

\section{RUTA BAGAS}

I oz. will plant a 100 -foot row 3 lbs. will plant an acre

Improved Purple Top Fellow.....7c Buckbee's Giant New Monarch, or Elephant.......... $7 \mathrm{c}$ 10c $25 \mathrm{c}$ Buckbee's Mam. White Russian...7 7c l0c 250

\section{Notice}

Full descriptions are given in our big illustrated annual catalog, copy of which rou have. Write for special quotations on larger quantities. 


\section{Vegetable Roots For Fall Planting}

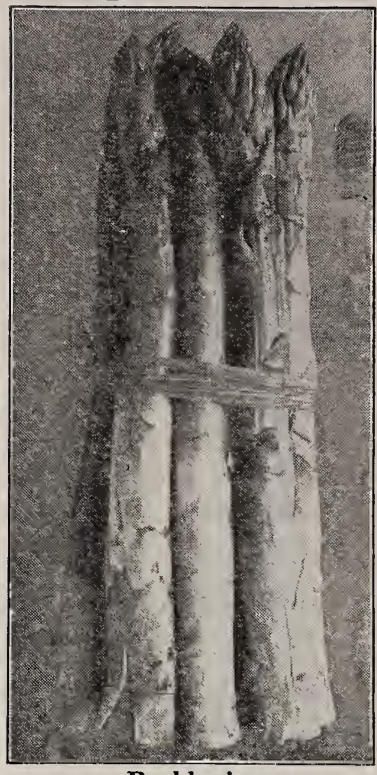

\section{ASPARAGUS ROOTS}

Every home and kitchen garden should have a bed of Asparagus. The growing popularity which this most delightful and wholesome vegetable has attained the past few years is remarkable. Without question, it is one of the most favorite and profitable garden crops: and makes a return early in the Spring before any other out-door crop can be marketed, and when a bed is thoronghly established will yield splendid crops for a number of years.

\begin{tabular}{|c|c|c|c|c|}
\hline \multirow{2}{*}{ Two Year Old Roots } & \multicolumn{2}{|c|}{ Postpaid } & \multicolumn{2}{|c|}{$\begin{array}{c}\text { Not } \\
\text { Prepaid }\end{array}$} \\
\hline & $\begin{array}{l}\text { Per } \\
\text { Doz.l }\end{array}$ & $\begin{array}{l}\text { Per } \\
100\end{array}$ & $\begin{array}{l}\text { Per } \\
100\end{array}$ & $\begin{array}{c}\text { Per } \\
1000\end{array}$ \\
\hline Washington Rust Proof. & $\$ 0.50$ & $\$ 2.25$ & $\$ 1.95$ & $\$ 17.50$ \\
\hline Buckbee's Perfection ... & .40 & 1.95 & 1.60 & 12.50 \\
\hline Bonvallet's Giant $\ldots \ldots \ldots \ldots \ldots$ & .35 & 1.90 & 1.50 & 11.75 \\
\hline Columbian Mammoth White... & .35 & 1.75 & 1.35 & 11.00 \\
\hline New Palmetto $\ldots \ldots \ldots \ldots \ldots \ldots \ldots$ & .30 & 1.75 & 1.40 & 10.50 \\
\hline Conover's Colossal & .30 & 1.50 & 1.25 & 9.85 \\
\hline
\end{tabular}

For success and immediate results we recommend planting three and four year old roots.

Owing to the many and numerous requests of our customers for the largest sized roots we have especially grown a fair supply of selected 3 and 4 year old roots to meet this demand. Our price, as long as the supply lassts, on any of the varieties listed above, except New Washington Rust Proof, only 65e per doz.; $\$ 3.50$ per 100, postpaid. By express or freight at buyer's expense, $\$ 2.50$ per $100 ; \$ 18.50$ per 1000 .

We also have a limited quantity of extra large 4-year old roots of Washington Rust Proof at the following prices: 90c per doz.; $\$ 4.95$ per 100 . By ex-

\section{Perfection Asparagus \\ EGYPTIAN OR PERENNIAL TREE WINTER SETS}

This variety never forms a large bulb. Its value lies wholly in its special adaptability to produce green Ouions for Spring or Fall uses. It is perfectly hardy, and when once set out will come up year after year. Can be planted either in Spring or Fall. We can supply these sets for shipment from September 1 to the following March. This variety increases by producing sets at the top of the stalk and does not produce seed. Postpaid, 1/2 lb. 18c; lb. 30c; 3 lbs. 80c; by express collect, $1 / 8$ bu. $55 c$; $1 / 4$ bu. 95 ; bu. $\$ 3.25$.

\section{THE BEST HERB PLANTS}

A portion of the garden should be devoted to Herbs, as their uses are many and varied. Here are a few very popular Herb Plants that may be planted in the fall.

CHIVES-20c each; 3 for 50c; dozen $\$ 1.75$, postpaid.

LAVENDER-25c each; 3 for 70c; dozen \$2.50, postpaid.

PEPPERMINT-25c each; 3 for 60c; dozen $\$ 2.25$, postpaid.

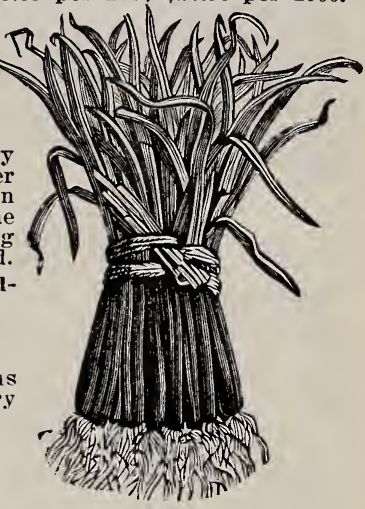

Onion Sets

SAGE-Buckbee's Giant-30c each. 3 for $75 c$; dozen, $\$ 2.50$, postpaid. SAGE - Holt's Mammoth-25c each; 3 for $55 \mathrm{c}$; dozen $\$ 1.75$, postpaid.

\section{PIE PLANT OR RHUBARB ROOTS}

A saving of from two to three years is made by planting the roots.

BUCKBEE'S NEW PINEAPPLF -Price, by mail, postpaid, each 25c; doz. $\$ 2.50$; by express or freight, not prepaid, each 20c; doz. $\$ 2.00 ; 100$ for $\$ 15.00$.

BUCKBEE'S WESTERN MARKET-Price, by mail, postpaid, each 20c: doz. $\$ 2.00$; by express or freight, not prepaid, each $15 \mathrm{c}$; doz. $\$ 1.50 ; 100$ for $\$ 10.00$.

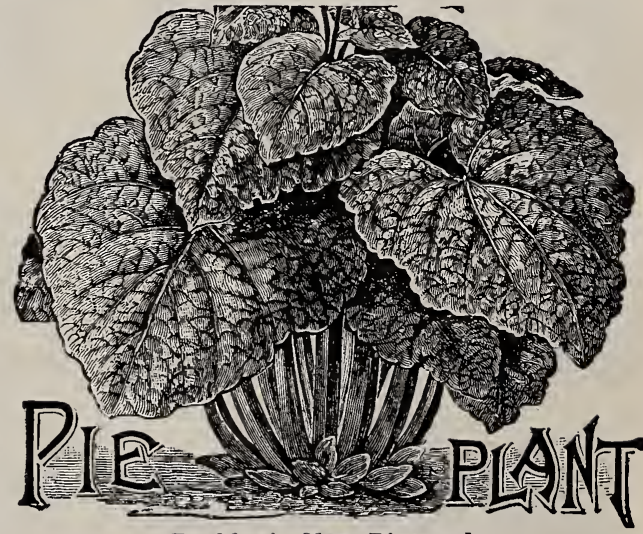

Buckbee's New Pineapple 


\section{Buckbee's "Full of Life" Wheat $\begin{gathered}\text { FoR FALL } \\ \text { SOWING }\end{gathered}$}

\section{NEW ILLINOIS DISEASE RESISTANT 10-100}

The Greatest Wheat Erer Grown. Plump, Bright and Clean and $a$ Wonderfully Heary Yielder.

This New Wheat is so far ahead of an Winter Wheat erer grown that we believe it will soon be grown to the exclusion of all others. It is the best. most reliable and most productive of all Winter Wheats. Originated bs the IIlinois State Experimental Station at Urbana, Illinois, and is recommended bs the Illinois Department of Agriculture. A strong. sturdy grower and stands up well. It is always an exceptionalls hears vielder of bright, hears grain which is bearded and unusualls large. The seed that we are offering is all grown from certified seed stocks and showed a purity of 99.6 pure in strain. This world beating Winter Wheat has actually out-yielded other rarieties the past season br fifty per rent. Send to H. $W$. BUCKBEE, Rockford Seed Farms for genuine Seed.

Postpaid, 3 lbs. 65c; by express, collect, $1 / \mathrm{s}$ bu. $45 \mathrm{c}$; $1 / 4$ bu. $85 \mathrm{c}$; bu. \$2.75

\section{HARVEST KING}

Popular beardless rariets: rery hardy; rigorous growth; great stooling propensities. and for productireness and good milling qualities it has few equals.

Postpaid, 3 lbs. 50c; by express, collect, $1 / \mathrm{s} \mathrm{bu}, 45 \mathrm{c} ; 1 / 4 \mathrm{bu}$. $75 \mathrm{c} ; \mathrm{bu}$. $\$ 2.30$.

\section{BUCKBEE RED TURKEY}

This is a bearded variety and is the hardiest known. The heads are long. well filled with large, flinty grains of reddish-amber color.

Postpaid, 3 lbs. 50c; by express, collect, $1 / \mathrm{s}$ bu. $40 \mathrm{c}$; $1 / 4$ bu. $65 \mathrm{c}$; bu. $\$ 2.10$.

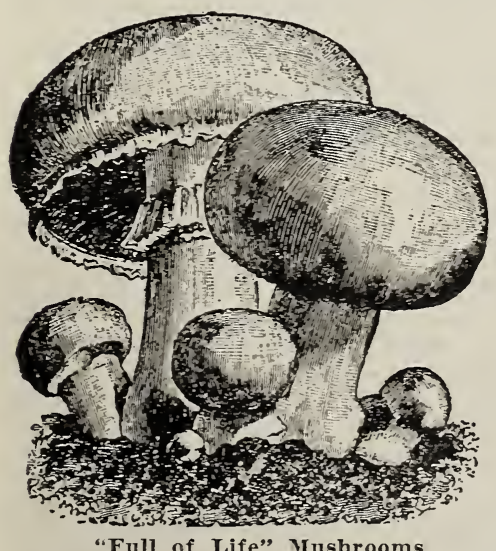

"Full of Life" Mushrooms

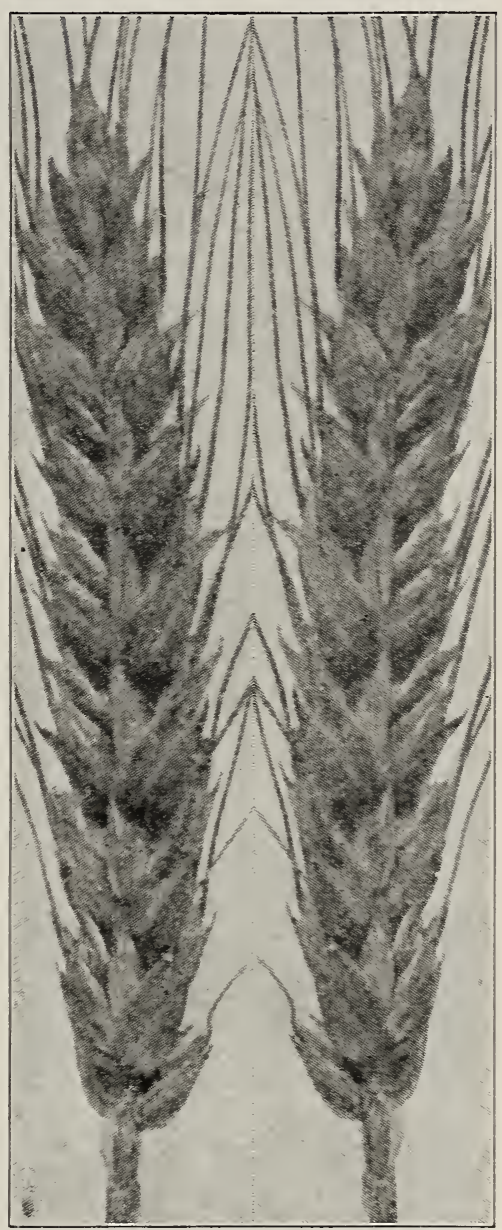

New Illinois $10-100$ Disease Resistant Wheat

\section{BUCKBEE'S 'FULL OF LIFE" MUSHROOMS}

High Grade, Pedigreed, Virgin Spawn

Get reliable spawn. start right and the results are sure to be satisfactorr. Complete cultural directions accompany each order.

\section{BUCKBEE'S SERE CROP SPAWN}

By mail, postpaid, brick 45c. By express, collect, bricks $35 \mathrm{c}$; 5 bricks $\$ 1.35 ; 10$ bricks $\$ 2.50 ; 25$ bricks $\$ 5.50 ; 100$ bricks $\$ 18.75$.

\section{BCCKBEE'S HIGH GRADE ENGLISH SPAWN}

By mail, postpaid, brick 40c. By express, collect, brick 25c; 5 bricks $\$ 1.05 ; 25$ bricks $\$ 3.25$.

These prices good until October 15, 1928, ask for new price list after that date. 


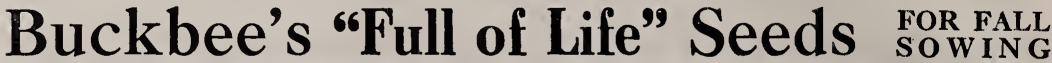
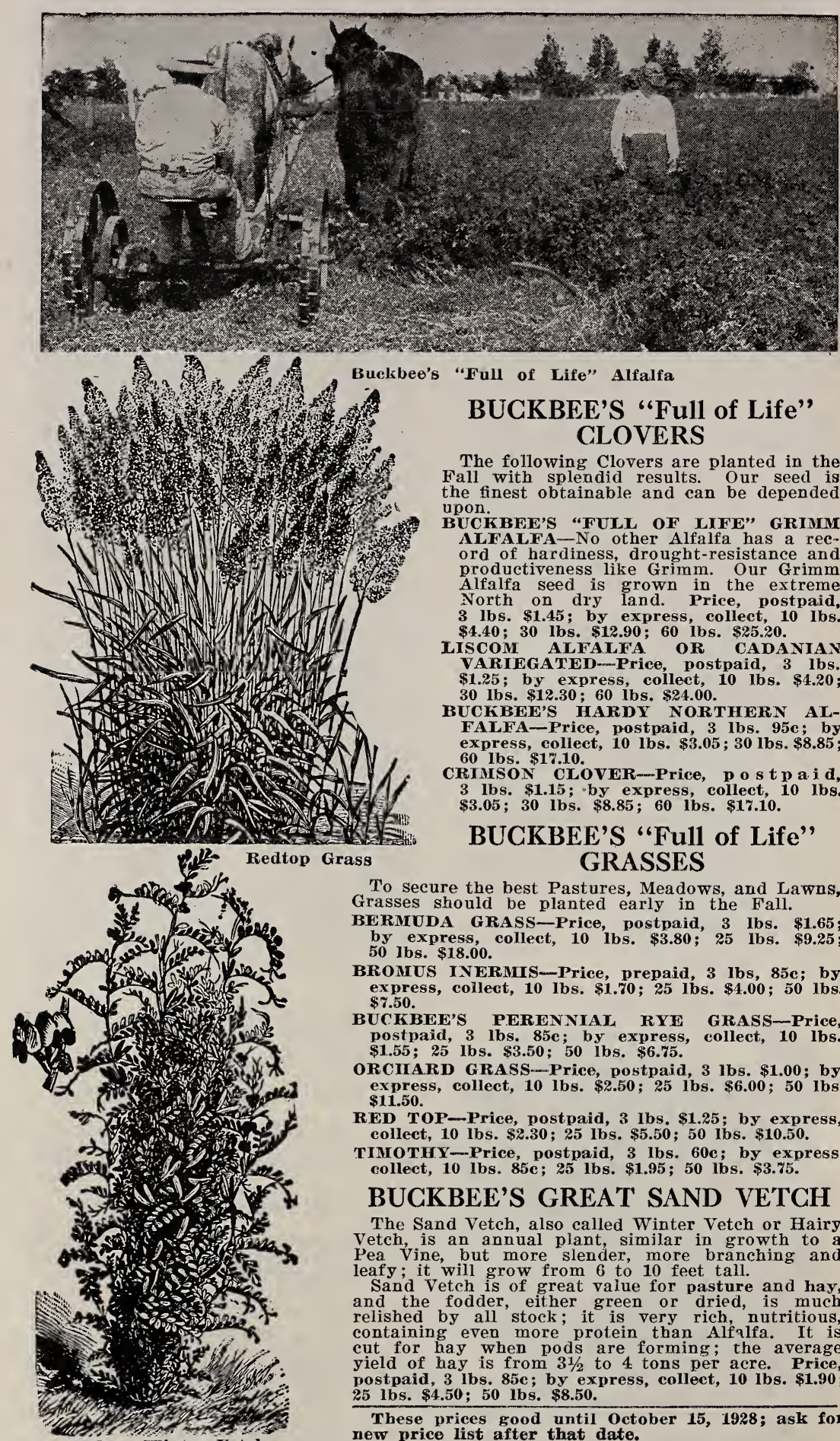

To secure the best Pastures, Meadows, and Lawns, Grasses should be planted early in the Fall.

BERMUDA GRASS-Price, postpaid, 3 lbs. \$1.65; by express, collect, 10 lbs. $\$ 3.80 ; 25$ Ibs. $\$ 9.25$; 50 1bs. $\$ 18.00$

BROMUS INERMIS-Price, prepaid, 3 lbs, 85c; by express, collect, 10 Ibs. $\$ 1.70$; 25 Ibs. $\$ 4.00 ; 50$ lbs. $\$ 7.50$.

BUCKBEE'S PERENNIAY RYE GRASS-Price, postpaid, 3 Ibs. 85c; by express, collect, 10 lbs. $\$ 1.55 ; 25$ lbs. $\$ 3.50 ; 50$ lbs. $\$ 6.75$.

ORCHARD GRASS-Price, postpaid, 3 lbs. $\$ 1.00$; by express, collect, 10 lbs. $\$ 2.50 ; 25$ lbs. $\$ 6.00 ; 50$ lbs $\$ 11.50$.

RED TOP-Price, postpaid, 3 lbs. \$1.25; by express, collect, 10 lbs. $\$ 2.30$; 25 Ibs. $\$ 5.50 ; 50$ lbs. $\$ 10.50$.

TIMOTHY - Price, postpaid, 3 lbs. 60c; by express, collect, 10 Ibs. 85e; 25 lbs. \$1.95; 50 lbs. $\$ 3.75$.

\section{BUCKBEE'S GREAT SAND VE'TCH}

The Sand Vetch, also called Winter Vetch or Hairy Vetch, is an annual plant, similar in growth to a Pea Vine, but more slender, more branching and leafy; it will grow from 6 to 10 feet tall.

Sand Vetch is of great value for pasture and hay, and the fodder, either green or dried, is much relished by all stock; it is very rich, nutritious, containing even more protein than Alfalfa. It is cut for hay when pods are forming; the average yield of hay is from $3 \frac{1}{2}$ to 4 tons per acre. Price, postpaid, 3 lbs. 85e; by express, collect, 10 Ibs. $\$ 1.90$; 25 lbs. $\$ 4.50$; 50 lbs. \$8.50.

These prices good until october 15, 1928; ask for Sand or Winter Vetch 


\section{Buckbee's "Full of Life" Seeds $\begin{gathered}\text { FOR FALL } \\ \text { SOWING }\end{gathered}$}

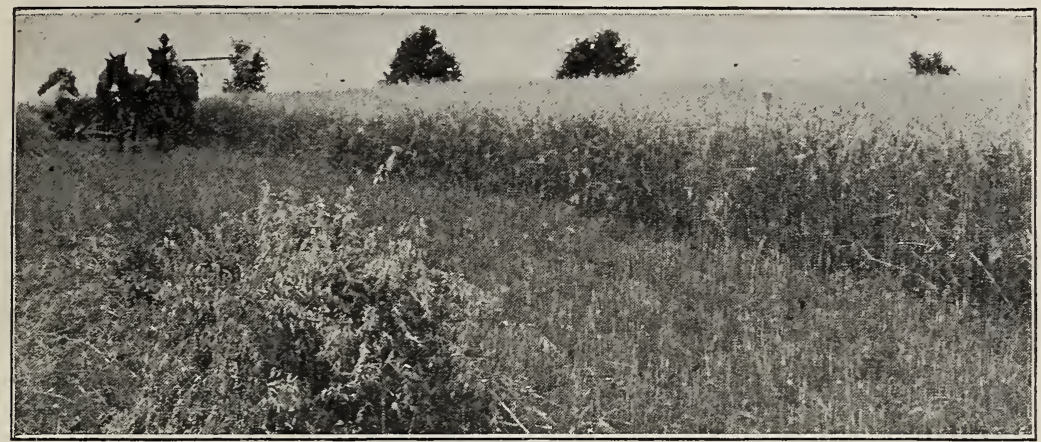

\section{WINTER OATS}

Winter Oats are of the greatest value for the states south of the Missouri line. They are grown there for Fall and Spring pasture and for grain. They also generally stand the winter everywhere in our state and in the southern half of Iowa. Our Winter Oats grown in the North are incomparably superior to southern-grown stock. They are more hardy, earlier, less susceptible to rust, of more vigorous growth, stand up better and are more productive.

NEW APPLER WINTER OATS -Price, postpaid, 3 lbs. 65c; by express, collect, $1 / 4$ bu. $45 c$; $1 / 2$ bu. $80 \mathrm{c}$; bu. $\$ 1.50$.

TEXAS RED RCST-PROOF

WINTER OATS-Price, post-

paid; 3 lbs. 60c; by express, collect, $1 / 4$ bu. $40 \mathrm{c} ; 1 / 2$ bu. $70 \mathrm{c} ;$ bu. $\$ 1.20$.

WIXTER TURF OATS-Price, postpaid, 3 lbs. 70c; by express, collect, $1 / 4$ bu. $70 \mathrm{c}$ $1 / 2$ bu. \$1.25; bu. \$2.30.

Rape-Buckbee's Dwarf Bonanza

Indispensable for Raising Sheep. and Hogs. Rape is used as a soiling crop in many places, but its chief use is for pasture and especially for sheep and hogs; its fattening properties are twice as good as those of clover. Sow in Fall after the grain is harvested or in the corn during the last cultivation.

Price, postpaid, 3 lbs. 75c; by express col lect, 10 lbs. $\$ 1.30 ; 25$ lbs. $\$ 3.00 ; 50$ lbs. $\$ 5.40$

\section{Rape-Dwarf Essex}

This is the variety known and grown everywhere. Not quite so strong and vigorous a grower as our Dwarf Bonanza, but never fails to give the best satisfaction. Fine imported seed.

Price, postpaid, 3 lbs, 60c; by express col lect, 10 lbs. \$1.20; 25 lbs. $\$ 2.75 ; 50$ lbs. $\$ 5.00$ New Rosen Winter Rye

This famous rye, originated by the Michigan Experiment Station, has now proven its superiority over all other varieties in every rye-producing section. It has doubled the yield obtainable with any other kind. The average yield of common rye in this country is less than 15 bushels per acre, but that of Rosen Rye 40 to 45 bushels. Rosen Rre has very stiff straw and very large heads with four even rows filled with very large kernels. It is characteristic of the Rosen that the four rows are always evenly well filled on 99 per cent of the heads, while common rye seldom shows a well-filled head. We offer genuine pure, clean stock.

Price, postpaid, 3 lbs. 55̃c; by express, collect, $1 / 4$ bu. 55c; $1 / 2$ bu. $\$ 1.05 ;$ bu. $\$ 1.90$. These price good until October 15, 1928; ask for new price list after that date.

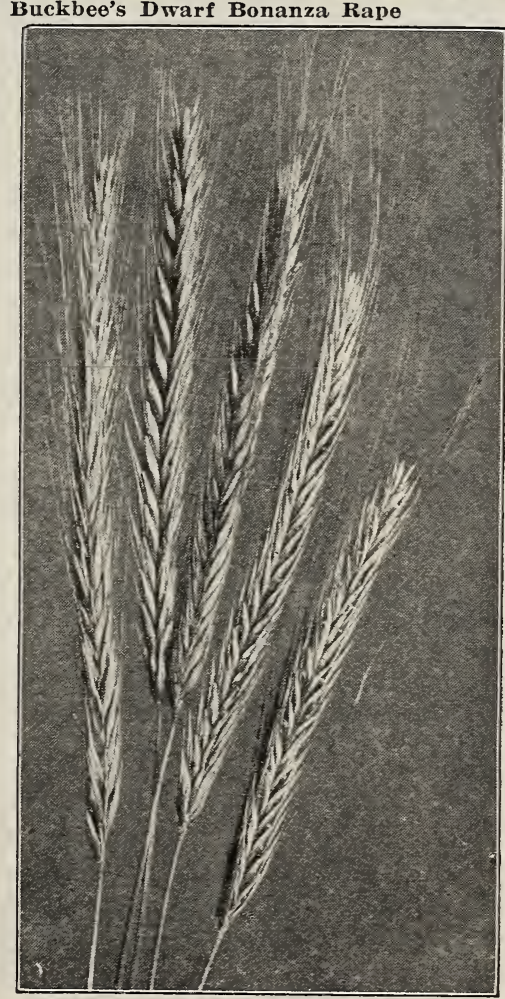




\section{FALL AND WINTER NEGESSITIES}

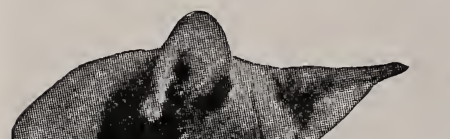

\section{KEN-L-RATION}

In the fall and winter when your dog does not get outside as much as he should, you should be very careful how you feed him.

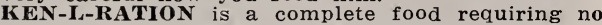
preparation whatever. It is balanced food. You cannot improve it by adding thereto. Open a can and serve on clean paper or dish. It is rich in meat, cereal, ground bone and cod liver oil. It is not a fattening food but will keep your dog in perfect health and condition if fed regularly. Keep a supply on hand. Purchased by the case, you have on unequalled balanced ration on hand at all times at an exceptionally low price.

Original cases Ken-L-Ration (48 1-lb. cans) for $\$ 6.48$ shipped by express or freight at buyer's expense.

Sample 1-lb. cans Ken-L-Ration 15c by express or 22c post paid.

BUCKBEE'S INCOMPARABLE PLANT FOOD

Odorless, Soluble Harmless, Efficient, Easy to Apply-Comes in Tins with Removable Tops for Convenient Use

All plants need a tonic occasionally to keep them in best condition. There are many plant foods on the market but most of them have so strong an odor as to make them very objectionable. In our new incomparable Plant Food this fault has been entirely overcome without sacrificing its efficiency in the least. Ammonia, Potash, Bone, Blood and Nitrate are all carefully blended in just the right proportions. Absolutely harmless to plant or to animals, is clean and effective. Sprinkle on the soil in the pot just enough at a time to color the surface. 'Try it. It is just what you have been looking for. Large can 30c, postpaid.

BUCKBEE'S COMBINATION LAWN AND GARDEN INVIGORATOR

The Wonder Fertilizer-The Marvelous Lawn Tonic-The Unequalled Garden Medicine In the fall you should give your lawn

50 Lbs.
Buckbee's
cOMBINATION
LAWN
GARd
GNDIGORATOR
HW.BUCKBEE
ROCKFORD,ILL.
and garden a liberal dressing of Buckbee's Invigorator, so as to have the land in fine shape the next spring. Keep a bag on hand always. You will need it almost the year around. Packed in 3 size bags to meet all requirements. Shipped by Express or Freight at buyer's expense. 25 lbs. $\$ 1.65$ 50 1bs. $\$ 2.60 ; 100$ lbs. $\$ 4.25$.
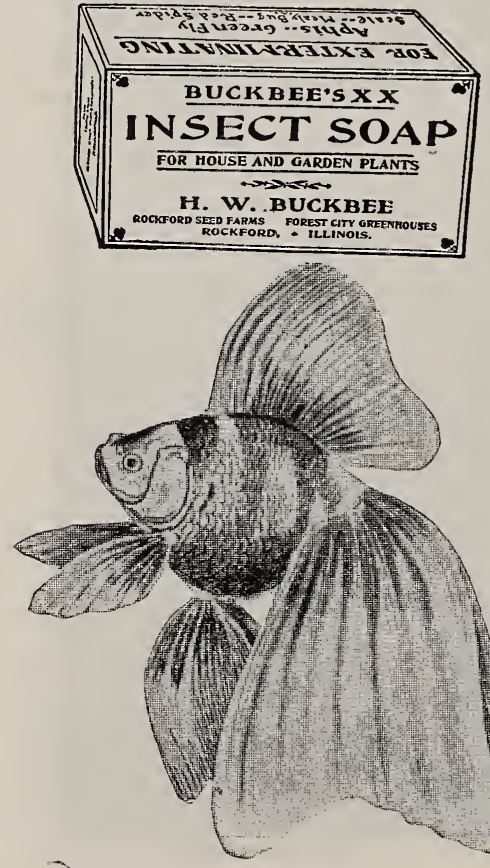

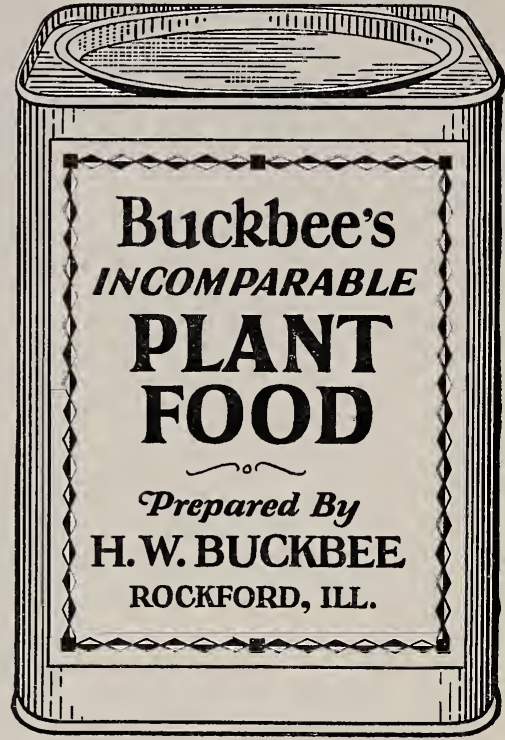

BUCKBEE'S XX INSECT AND PLANT SOAP A Pure, Clean, Harmless, odorless Soap for Washing House Plants and Palms

Although a plant may appear perfectly healthy and clean, it is surprising what a difference it will make when washed with Buckbee's XX Plant Soap. A small piece dissolved in lukewarm water and stirred well until it suds, then applied to the plant either as a spray or washed well with soft sponge, is all that is necessary.

Price per cake, sufficient for 2 gallons prepared solution, 25c, postpaid.

THE NEW ROCKFORD FISH FOOD

Most everyone has a few Gold Fish in the home and need a well-balanced, palatable, clean and economical food. Try a box and you will never again be without it.

Sample box 15c, postpaid.

A BIG BARGAIN Indispensable for House Plants

Plant Sprinkler

90c each

Postpaid

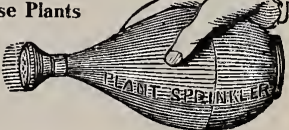


BUCKBEE'S “FULL OF LIFE' LAWN GRASS SEED

Yakes a Perfect Lawn. Hardy, Luxuriant, Always Grows. It Seems as Natural to Plant Grass Seed in the Spring as It Does to Make a Garden. Regardless of That, Fall sowing Is the Best.

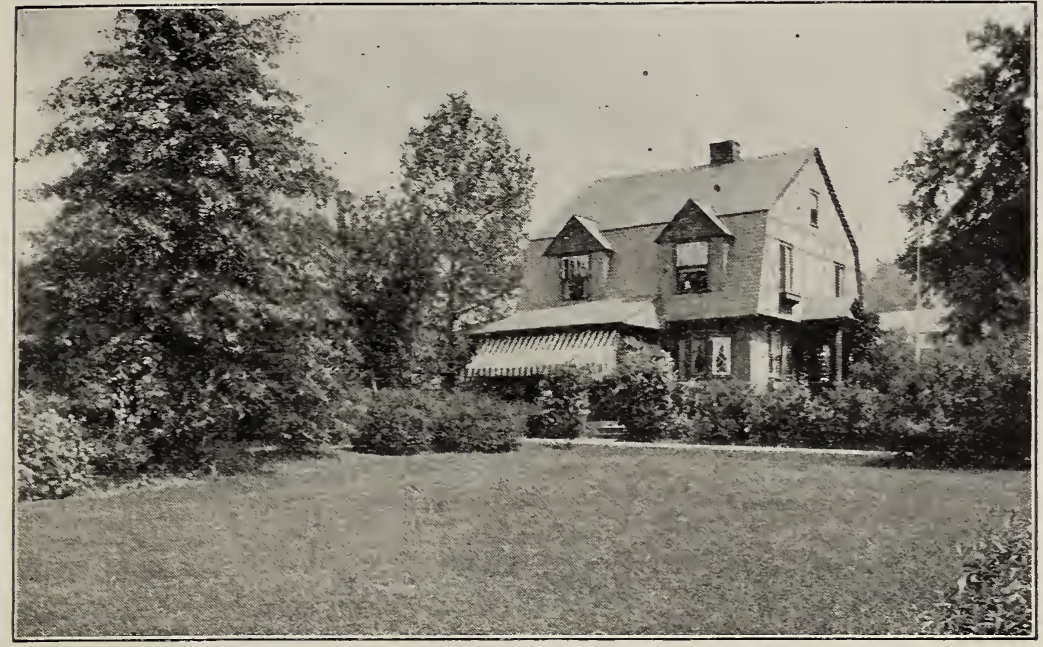

BUCKBEE'S WORLD'S FAIR LAWN GRASS SEED

THE VERT BEST LATN SEED EVER OFFERED

This famous Prize-Winning Lawn Grass is made up of a most erenly balanced combination of natire and foreign fine-leared, deep-rooting grasses that interweare and flourish in different soils and climates, each showing its best strength at seasons different from the others, and thus keeping the lawn rigorous and green from Winter's end to Winter's next adrent.

It is unrivaled for purity and luxuriance in growth and will give complete satisfaction whererer sown. With ordinary care, anyone can, br using this mixture, secure a beautiful lawn. Complete and explicit directions on "How to Make a Lawn" accompany erery package of this seed. The quantity table on this page shows the mount of seed to plant in a giren area. Price, postpaid, $1 / 21 b .30 c ; 1 b .50 c$; 3 lbs. \$1.35. Larger quantities by express or freight, not prepaid, 5 ibs. \$2.25; 10 lbs. $\$ 4.40 ; 15$ lbs. $\$ 6.45 ; 25$ lbs. $\$ 10.50$.

\section{SHADY PLACE LAWN GRASS SEED}

CAREFCLLY BLENDED FOR SHELTERED AND SHADY PLACES

On nearly all lawns there are unsightly bare spots under the shade of trees, which hare baffled all efforts to get into grass, but with this mixture there need be no further difficulty. It is a combination of fine dwarf-growing, erergreen rarieties *hich in their wild or natural state are to be found growing in the woods or other sheltered and shaded spots. Ground that has been densely shaded br trees is frequently "sour" and if the drainage is defectire it is apt to be corered with moss and coarse bog grasses. In such cases an application of slake lime, at the rate of one bushel to each thousand square feet, or 40 bushels to the acre, is an excellent correctire and sweetener, but the moss should be first remored.

Price, postpaid, $1 / 2$ lb. 35c; lb. 55c; 3 lbs. \$1.45. By express or freight, not prepaid, 5 lbs. $\$ 2.75 ; 10$ lbs. $\$ 5.40 ; 15$ lbs. $\$ 7.95 ; 25$ lbs. $\$ 13.00$.

\section{VELVET GREEN LAWN GRASS SEED}

\section{A SPLENDID STANDARD MIXTURE}

This special mixture does not include so great a number of expensive grasses as our "World's Fair Mixture," but full provision is made for a succession of growth and a careful blending in proper proportion and thoroughly mixed for quickly producing a permanent. thick and relvety sward of uniform growth and rich green grass free from coarseness. Prices, postpaid, $1 / 2$ lb. 20c; lb. 35c; 3 lbs. 90c. By express or freight, not prepaid, 5 lbs. $\$ 1.40 ; 10$ lbs. $\$ 2.70 ; 25$ lbs. $\$ 6.50$.

\section{WHITE CLOVER (For Lawns)}

This is a valuable pasturage and lawn grass. thrives best on moist, rich ground; does not succeed well on thin soil. Makes excellent forage for Bees. In conjunction with Kentucky Blue Grass it forms a desirable permanent pasture for sheep and cows. Postpaid, 1b. 60c; 3 lbs. \$1.65.

\section{KENTUCKY BLUE GRASS}

\section{EXTRA FANCY}

Our "Full of Life" Seed is unsurpassed. Many prefer this to a mixture of grasses, and the fact cannot be denied that a lawn of Blue Grass is magnificent; it takes longer, howerer, to get it established. Verv desirable for wood lawns, pastures. and especially excellent for winter pastures because of its thick, hears growth. Price, postpaid, lb. $45 \mathrm{c} ; 3$ lbs. $\$ 1.30$. By express or freight, not prepaid, 5 lbs. $\$ 1.95$; 10 lbs. $\$ 3.80 ; 25$ lbs. $\$ 9.00$.

\section{Quantity of Lawn Grass Seed to Use}

$1 \mathrm{lb}$. for $350 \mathrm{square} \mathrm{ft}$. $25 \mathrm{lbs}$. for one-fourth acre. 5 lbs. for 1750 square ft. 50 lbs. for one-half acre. $10 \mathrm{lbs}$. for 3500 square ft. $100 \mathrm{lbs}$. for one acre. 15 lbs. for 5250 square $\mathrm{ft}$.
WRITE FOR

Special Quotations For Lawn Grass

In Large Quantities 


\section{"FULL OF LIFE" BUILBS, SEEDS, PLA N"TS}

SPECIAL BULB CULTURE

For all Dutch Bulbs which are Planted Out Doors in Fall for Early Spring Flow. ering.

Notice the diagram, as it is a whole book in itself. telling how deep and how far apart the different bulbs should be planted. Of course one should have good rich soil, and a sunny situation. That is really all there is to it. Out-doer planting should be done early in the Fall to secure healthy plants, vigorous foliage and beautiful flowers.

Our Special Leaflet on Bulb Culture for out-door and in-door planting Sent Free witu All Orders for Bulbs selected from this Catalogue.

FAIR PLAY GUARANTEE

FIRST-We guarantee that all goods sold from this catalogue shall reach customers in good condition.

SECOND-Terms Cash with Order (we keep no book accounts). No goods sent C. O. D. We guarantee to hold ourselves responsible for the safe arrival of all remittances sent us by $\mathbf{P}$. O. Order, Bank Draft, Express Order or Registered Letter. On orders amounting to over $\$ 1.00$ the cost of remitting by any of these methods may be selected in extra bulbs or seeds free.

THIRD-We guarantee to deliver free of charge in the United States all Bulbs. Seeds and Plants listed in this catalogue, except such items as are plainly marked to be shipped by Express at purchaser's expense.

FOURTH-We guarantee Buckbee's "Full of Life" Bulbs, Seeds and Plants to be just as represented-if they prove otherwise, we will refill the order free of charge or refund the money paid us for same.

CUSTOMERS FROM CANADA AND FOREIGN COUNTRIES must send Twenty-five Cents additional for Postage and Packing on each Dollar's Worth of Seeds and Bulbs ordered. Remember please that we cannot accept Canadian or Foreign Postage Stamps.

NOTICE-If you are interested in other items of Seeds and Plants not listed in this Special Fall Catalogue please refer to

OUR BIG GENERAL CATALOGUE FOR 1928

which gives a complete list of Buckbee's "Full of Life" Seeds and Plants.

\section{READ THESE FEW WORDS ABOUT RELIABLE SEEDS}

From Good Seeds only can good crops be grown, yet a great many contingencies may arise to prevent the best seeds from giving satisfaction, and for all these reasons we cannot, of course, guarantee or be responsible for a crop, as success is dependent upon natural causes which are beyond human control. Therefore, we do not warrant in any way, express or implied, the contents, or the description, quality productiveness, or any other matter of any Bulbs, Seeds or Plants sold by us, and we will not in any way be responsible for the crop. If the purchaser does not accept these goods on above terms, no sale is made thereof, and he must return them at once, and the money will be refunded. Subject to above conditions we make this sale, at the moderate prices at which we sell our goods.

OUR BIG NEW CATALOGCE FOR 1929 will be issued about the first of the year; if you fail to receive your copy in proper season. kindly let us knom

Bulbs Ready for Shipment About September 15 th About September 15th Our stock of bulbs arrives from Holland early in September, and we will be ready to commence filling orders on or about the 15th of that month. You can send your order to us as soon as you receive this catalog and shipment will be made when we receive the bulbs from Holland. We advise the placing of orders early, as our stocks of all varieties may not be com-
plete late in the season.

RESURRECTION PLANT

Most Unique Novelty

A Marvel of Plant life

This peculiar plant is found among the pines and cedars of Palestine. It is a ball of tightly folded leaflets, dry and apparently dead. But a transformation takes place once it is dropped into a bowl of water, for in a short time there is a great, loose, expanded rosette of fine fernlike leaves, both odd and beautiful. This can be repeated many times, the plant curling tightly together when dry, expanding when soaked. 15c each; 3 for 40c; postpaid.

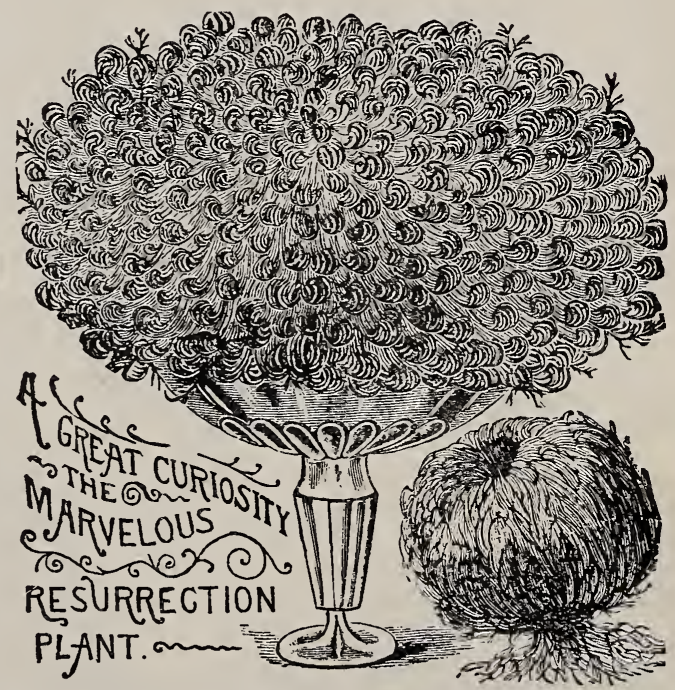

Rockford Seed Farms Rockford, Ill. 


\section{Buckbee's "Full of Life" Bulbs, Plants and Seeds}

\section{Rockford Seed Farms Forest City Greenhouses H.W. BUCKBEE Rocktord, Hilnols Zone}

Name

$$
\text { (Very Plain) }
$$

Post Office

State.

R. F. D. No.

Box No.

Street and No.

AMOUNT ENCLOSED

Cash, \$.

Postage Stamps, \$.
Please do not write here.

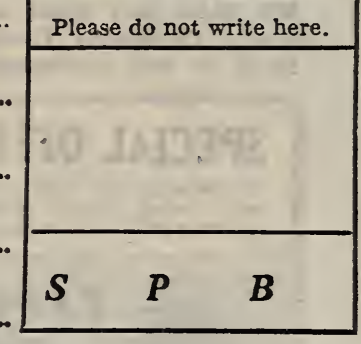

Money Order, \$.

Draft or Check, \$. you enclose.

Extra Order Sheets and Envelopes Sent Upon Application. Be Sure to Read Ordering Instructions, Catalogue Page 40.

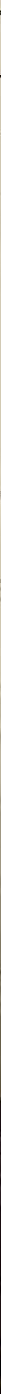




\section{QUALITY CHRISTMAS CARDS}

\section{Buy Your Christmas Cards at Cost}

We have just made arrangements with the largest manufacturers of High Grade Christmas Cards for three wonderful assortments and are offering them to our customers at rock bottom prices, delivered postpaid.

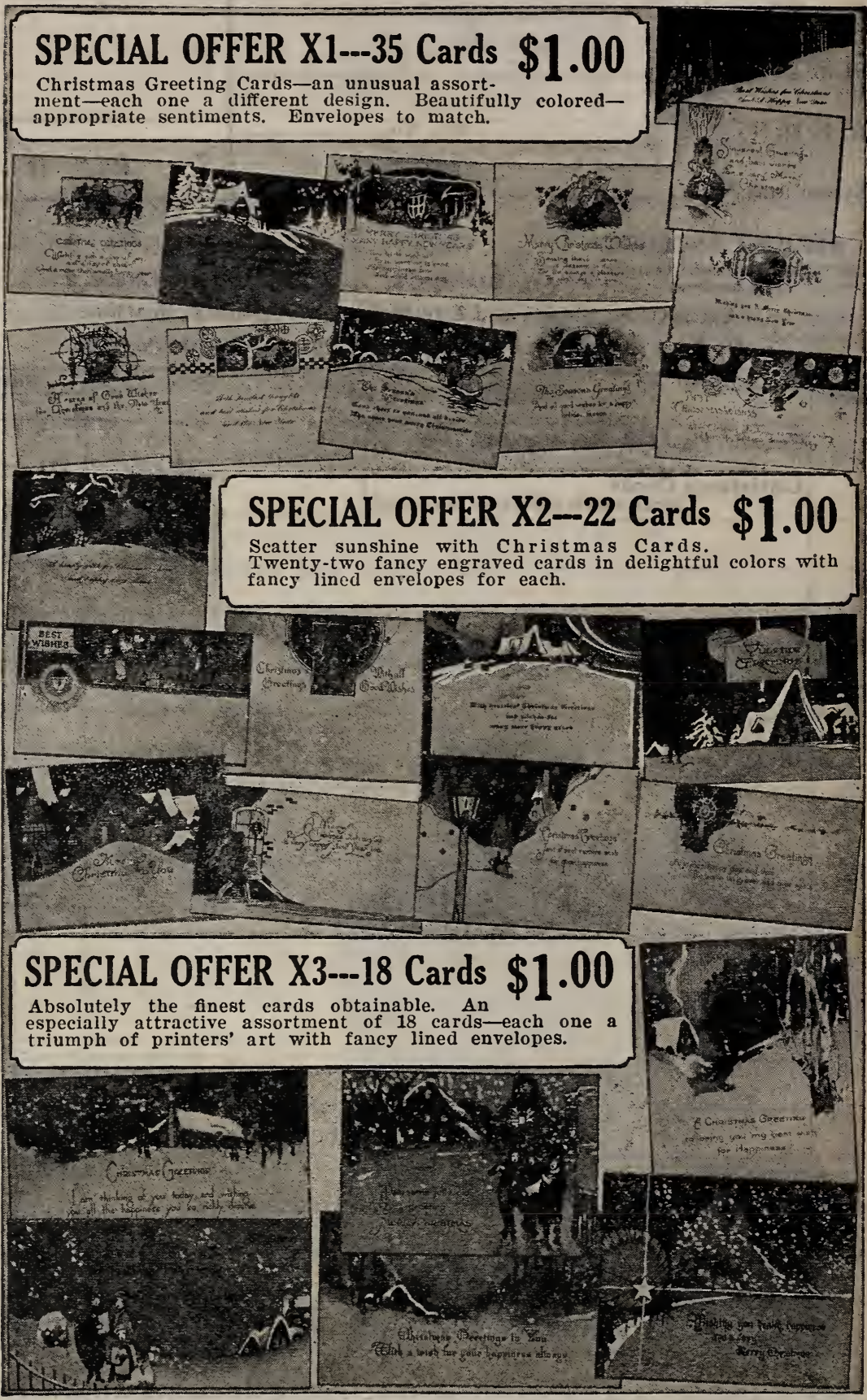




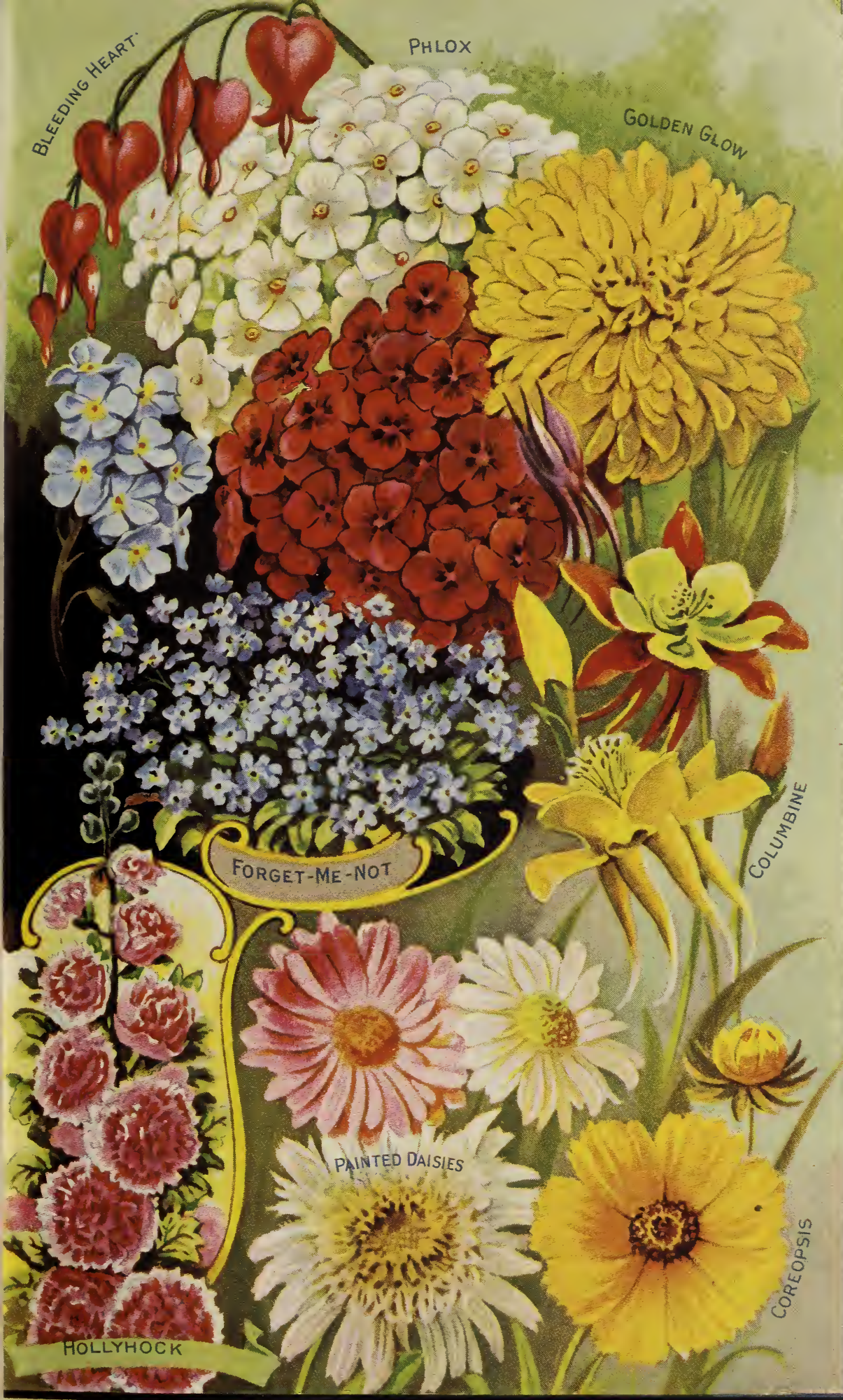

BUCKBEE'S BEAUTIFUL PERENINIAL COLLECTION

Absolutely Hardy

Eight. Easily Grown Varieties Shown On This Page.

One Strong Plant Each of the Eight Varieties for \$1.37, postpaid. 


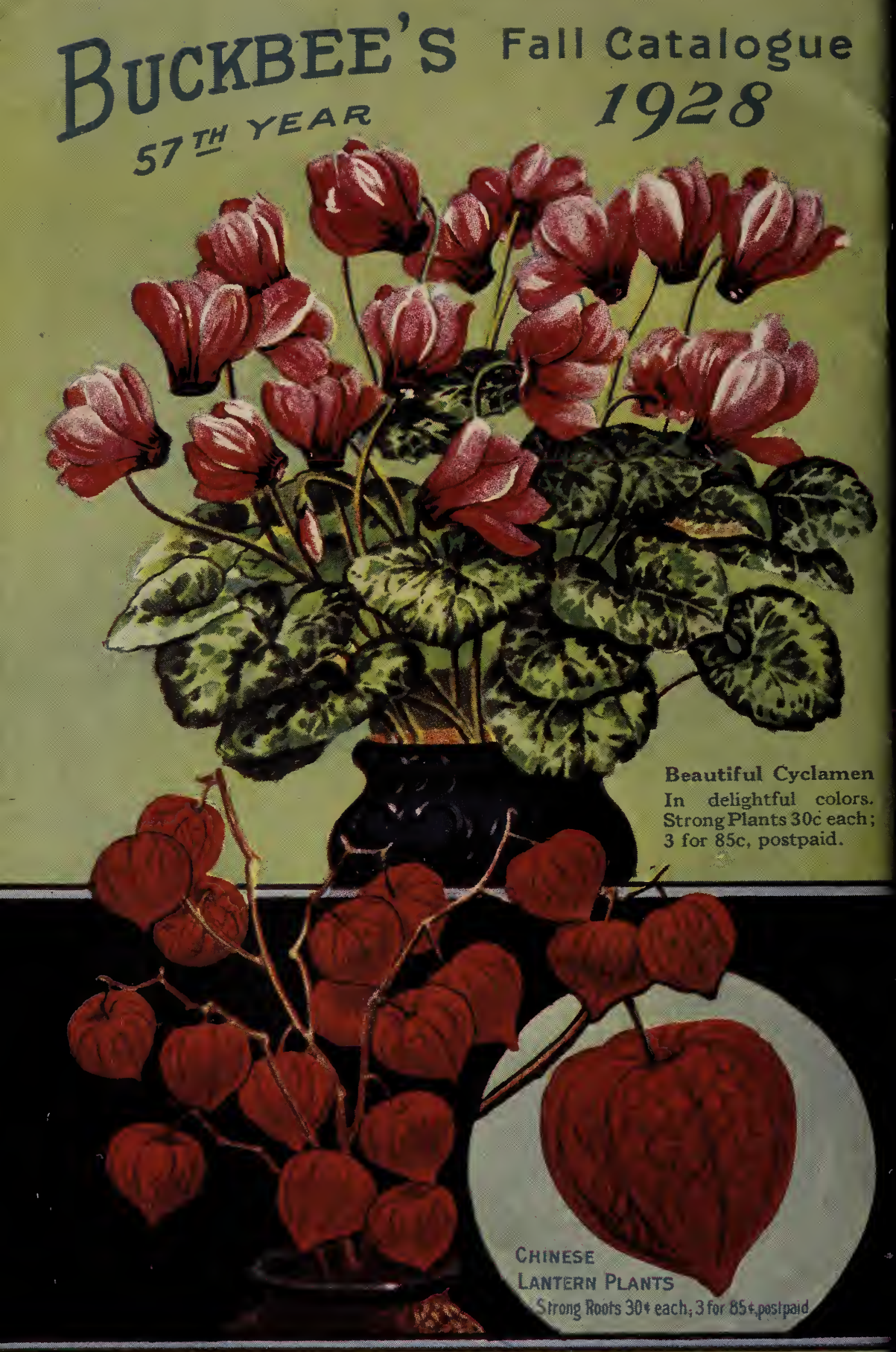

H. W. BUCKBEE, Rockford, Illinois Established 1871 